5030-462

Electric \& Hybrid Vehicle System

Research \& Development Project

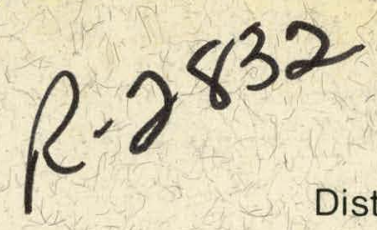

DOE/CS-54209-TI

Distribution Category UC-96

\title{
Electric and Hybrid Vehicles Charge Efficiency Tests of ESB EV-106 Lead-Acid Batteries
}

John J. Rowlette

January 15,1981

Prepared for

U.S. Department of Energy $A$ I I OI. $780 S 54209$

National Aeronautics and Space Administration

by

Jet Propulsion Laboratory

California Institute of Technology

Pasadena, California

(JPL PUBLICATION 80-94) 


\section{DISCLAIMER}

This report was prepared as an account of work sponsored by an agency of the United States Government. Neither the United States Government nor any agency Thereof, nor any of their employees, makes any warranty, express or implied, or assumes any legal liability or responsibility for the accuracy, completeness, or usefulness of any information, apparatus, product, or process disclosed, or represents that its use would not infringe privately owned rights. Reference herein to any specific commercial product, process, or service by trade name, trademark, manufacturer, or otherwise does not necessarily constitute or imply its endorsement, recommendation, or favoring by the United States Government or any agency thereof. The views and opinions of authors expressed herein do not necessarily state or reflect those of the United States Government or any agency thereof. 


\section{DISCLAIMER}

Portions of this document may be illegible in electronic image products. Images are produced from the best available original document. 


\section{Electric and Hybrid Vehicles Charge Efficiency Tests of ESB EV-106 Lead-Acid Batteries}

John J. Rowlette

January 15, 1981

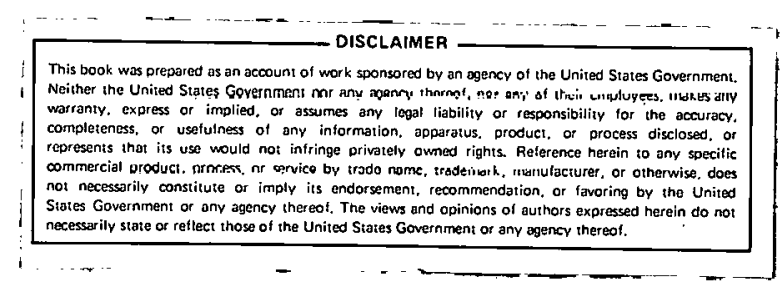

Prepared for

U.S. Department of Energy

Through an agreement with

National Aeronautics and Space Administration

by

Jet Propulsion Laboratory

California Institute of Technology

Pasadena, California

(JPL PUBLICATION 80-94) 
Prepared by the Jet Propulsion Laboratory, California Institute of Technology, for the U.S. Department of Energy through an agreement with the National Aeronautics and Space Administration.

This report was prepared as an account of work sponsored by the United States Government. Neither the United States nor the United States Department of Energy, nor any of their employees, nor any of their contractors, subcontractors, or their employees, makes any warranty; express or implled, or assumes any legal liability or responsihility for the accuracy. çompleteness or usefulness of any information, apparatus, product or process disclosed, or represents that its use would not infringe privately owned rights.

Refercnec hcrein to any specific commercial product, process, or service by trade name, trademark, manufacturer, or otherwise, does not netessurily curistitute or imply its endorsement, recommendation, or favoring by the United States Government or any agency thereof. The views and opinions of authors expressed heroin in not ner.essarily state or reflect those of the United States Government or any agency thereof. 


\section{ABSTRACT}

Charge efficiencies were determined for ESB EV-106 lead-acid batteries by measurements made under widely differing conditions of temperature, charge procedure, and battery age. The measurements were used to optimize charge procedures and to evaluate the concept of a modified, coulometric state-of-charge indicator. Charge efficiency determinations were made by measuring gassing rates and oxygen fractions. A novel, positive displacement gas flow meter which proved to be both simple and highly accurate is described and illustrated. 
ACKNOWLEDGEMENT

This research was conducted for the Electric and Hybrid Vehicle Project, sponsored by the U.S. Department of Energy through an agreement with NASA. I wish to thank the Project Manager, Thomas A. Barber, the Task Managers, Jack E. Marte and James E. Graf, and the Work Element Manager, Dean B. Edwards for their cooperation during the course of this work.

1 also wish to thank those people in the battery lab who worked hard in performing the tasks necessary to acquiring all the data presented in this report. Special thanks are extended to Larry Whitcanack for running the tests, including many hours spent making manual determinations of gas flow rates and reducing much of the data, and to Anthony Phillips for the time he spent in developing the software used on this testing program. 


\section{CONTENTS}

$1.0 \cdot$ Introduction................................

$2.0 \quad$ Purpose...................................

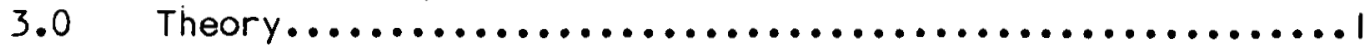

4.0 Experiment Description..........................

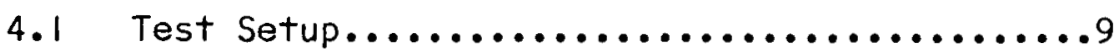

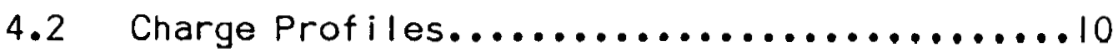

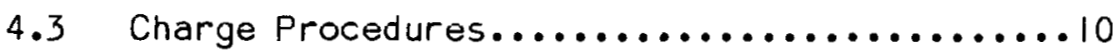

4.4 Discharge Procedures.................. 17

4.5 Temperature......................17

5.0 Experiment Description,

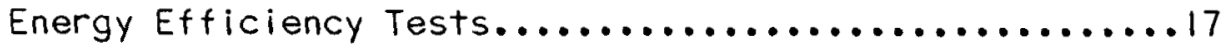

6.0 Measurements.............................. 8

6.1 voltage...........................

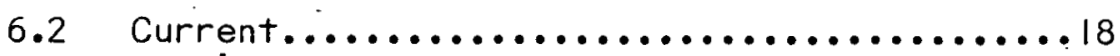

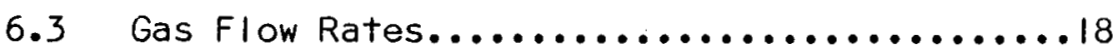

6.4 Oxygen Flow Rates.....................20

6.5 Hydrogen Flow Rates...................20

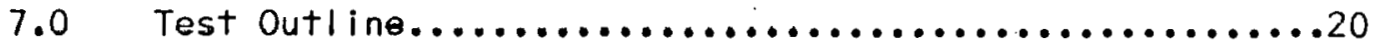

$8.0 \quad$ Results...................................

9.0 Observations and Conclusions......................

9.1 General Observations....................21

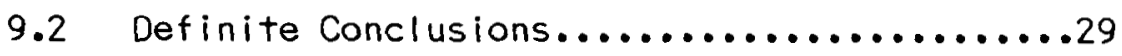

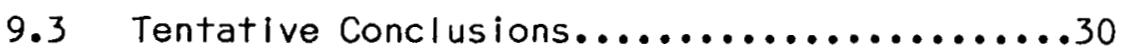




\section{CONTENTS}

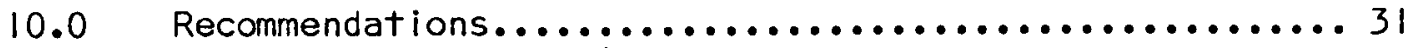

10.1 Charging Recommendations....................

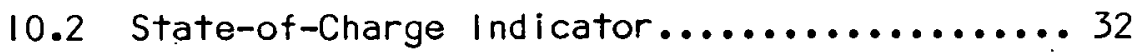

APPENDIXES

A. Coulombic Efficiency Tests of ESB EV-106

Lead-Acid Batteries........................ 43

B. Age Cycling of ESB EV-106 Lead-Acid

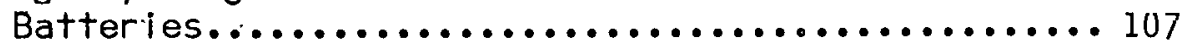

C. Energy Efficiency Tests of ESB EV-106

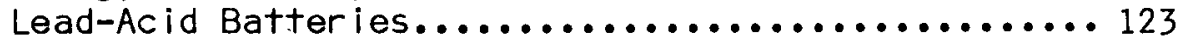

D. Open Circuit Voltage Versus State of Charge

for ESB EV-106 Lead-Acid Batteries...............139

E. Error Analysis for State-of-Charge Indication...... 143

\section{FIGURES.}

1. Coulombic Charge Efficiency.................. 5

2. Energy Charge Efficiency.................... 7

3. Charge Frofiles........................... 13

4. Gas Flow Meter........................... 19

5. Error Distribution for Capacity Prediction........ 146

\section{TABLES}

1. Charge Profiles and Procedures................. 12

11. Summinl y uf Tests......................... 22

111. Summary of Coulombic Efficiency Tests............ 33

IV. Summary of Energy Efficiency Tests............. 40

V. Analysis of Errors for State-of-Charge Indication.. 145 


\subsection{INTRODUCT ION}

In the near term, electric vehicles will probably be powered by leadacid batteries. An experimental program was conducted to better understand the charging efficiency of a lead-acid battery throughout the charging process. This understanding should result in improved charging methods, which could maximize charging efficiency and extent of charge, and perhaps extend the batteries' cycle life. Knowledge of the coulombic (ampere-hour) efficiency while the battery is being charged should also allow the development of a counterpart in electric vehicles of the fuel gauge in cars with internal combustion engines. This report describes experiments performed to improve battery charging procedures and to evaluate the concept of a modified coulometer for determining the state of charge of lead-acid batteries.

\subsection{PURPOSE}

The purpose of these tests was to provide information for the design of a battery charger that will allow maximum recharge efficiency for electric-vehicle batteries, consistent with such other operating parameters as range, water loss, and cycle life. The tests also provided information for the design of a coulometric type of state-of-charge indicator.

\subsection{THEORY}

When a lead-acid cell is being charged, all of the charging current goes into one of two electrochemical processes at each electrode. Either lead production and/or hydrogen generation occurs at the negative 
electrode, and lead dioxide production and/or oxygen generation occurs at the positive electrode. (The possibility exists for the sulfate to persulfate oxidation at very high charging potentlals, although we have not yet seen evidence of this reaction). It follows that the continuous determination of hydrogen and oxygen generation rates and total current flowing into the battery will allow a determination to be made of the charging current which is increasing the cell's state of charge. A coulombic (amp-hour) efficiency at any moment in time can also be calculated and, by summing the instantaneous efficiencies over the entire charge cycle, the overall coulombic efficiency can be calculated for the charge. If this is combined with similar information during discharge, it becomes possible to design an accurate coulometer state-of-charge indicator.

The electrolys is reaction:

$$
\mathrm{H}_{2} \mathrm{O} \longrightarrow \mathrm{H}_{2}+1 / 2 \mathrm{O}_{2}
$$

is the sum of two half-cell reactions:

$$
\mathrm{H}_{2} \mathrm{O} \longrightarrow 1 / 2 \mathrm{O}_{2}+2 \mathrm{H}^{+}+2 \mathrm{e}^{-}
$$

and

$$
2 \mathrm{H}^{+}+2 \mathrm{e}^{-} \longrightarrow \mathrm{H}_{2}
$$

From equation (1), it can be seen that for the passage of two equivalents (faradays) of electricity, one mole of hydrogen and half a mole of oxygen are evolved. Since a faraday is equal to $96,487.3$ 
coulombs (amp-seconds) it is further seen that one equivalent of a chernical reaction per cell is equal to $96,487.3+3,600$ or 26.802 Ah. It is seen from equation 2 that one equivalent results in $1 / 4$ mole of oxygen and (from equation 3) 1/2 mole of hydrogen. Measured at standard temperature and pressure $\left(0^{\circ} \mathrm{C}\right.$ and 1 atm.) this is $5,603 \mathrm{~cm}^{3}$ of oxygen and $11,206 \mathrm{an}^{3}$ of hydrogen. It is then readily calculated that:

$$
1 \mathrm{amp}=3.482 \mathrm{~cm}^{3} / \mathrm{min} \text {. of } \mathrm{O}_{2} \text { per cell @ STP }
$$

and

$$
1 \text { amp }=6.965 \mathrm{~cm}^{3} / \mathrm{min} \text {. of } \mathrm{H}_{2} \text { per cell @ STP }
$$

Until the beginning of full overcharge, when all of the current goes completely into gassing at both electrodes, there is no necessary relation between hydrogen evolution at the negative electrode and oxygen evolution at the positive electrode. Prior to full overcharge the current is dividing at each electrode, with more and more going into gassing as charging proceeds. Over a period of several cycles, there will be an equivalent amount of gassing from the two electrodes. These phenomena occur because, during discharge, the same capacity is removed from each electrode. On the subsequent recharge, the same number of amp-hours will be passed through each electrode. When the electrode of lower efficiency has been fully recharged, the higher efficiency electrode will, of course, have also been fully recharged. The olfference between the number of amp-hrs passed through the positive electrode and the charge put on that electrode will therefore be equal to the number of amp-hrs passed through the negative electrode and the charge given to it. The difference is, of course, due to gassing. 
While the cell is being charged, the state of charge of each electrode is being increased incrementally by an amount given by:

$$
d C=\left(I_{C}-I_{g C}\right) d t
$$

where dC is the incremental increase in capacity, $I_{c}$ is the total charging current passing through the cell, Igc is the charging current resulting in gassing at that electrode, as calculated by either equation(4) or equation (5), and $d t$ is the incremental charging time. If none of the current results in gassing, then equation (6) reduces to:

$$
d C=I_{C} d t
$$

An instantaneous current efficiency for the charging process can now be defined by:

$$
\eta I_{(c)}=\frac{\mathrm{l}_{\mathrm{c}}-\mathrm{Igc}_{\mathrm{g}}}{\mathrm{l}_{\mathrm{c}}}
$$

where $\eta$ Ic is the current efficiency for the charging process. For a complete charge from $t=0$ to $t=t_{f}$, the increase in capacity at each electrode is:

$$
c=\int_{0}^{t_{f}}\left(I_{c}-I_{g c}\right) d t
$$

where $C$ is the increase in capacity. A coulombic, or amp-hr (Ah) 
half-cycle efficiency for the charging process can be defined by:

$$
\eta \operatorname{Ah}(c) 1 / 2=\frac{\int_{0}^{t_{t}}\left(1_{c}-l_{g c}\right) d t}{\int_{0}^{t_{t}} l_{c} d t}
$$

where Ah (C) $1 / 2$ is the half-cycle efficiency during charge, and the integral in the denominator is the total, integrated charging current in amp-hrs. In order to make equation (10) meaningful, the integral in the numerator must refer to the increase in state of charge for the limiting electrode.

Figure 1 shows the form of the half-cycle charge efficiency curves for typical electrodes. Experimentally, the charging will be carried to near completion (i.e., where efficiency for the limiting electrode is near zero), but analytically one can find a time of charge to yield any desired efficiency.

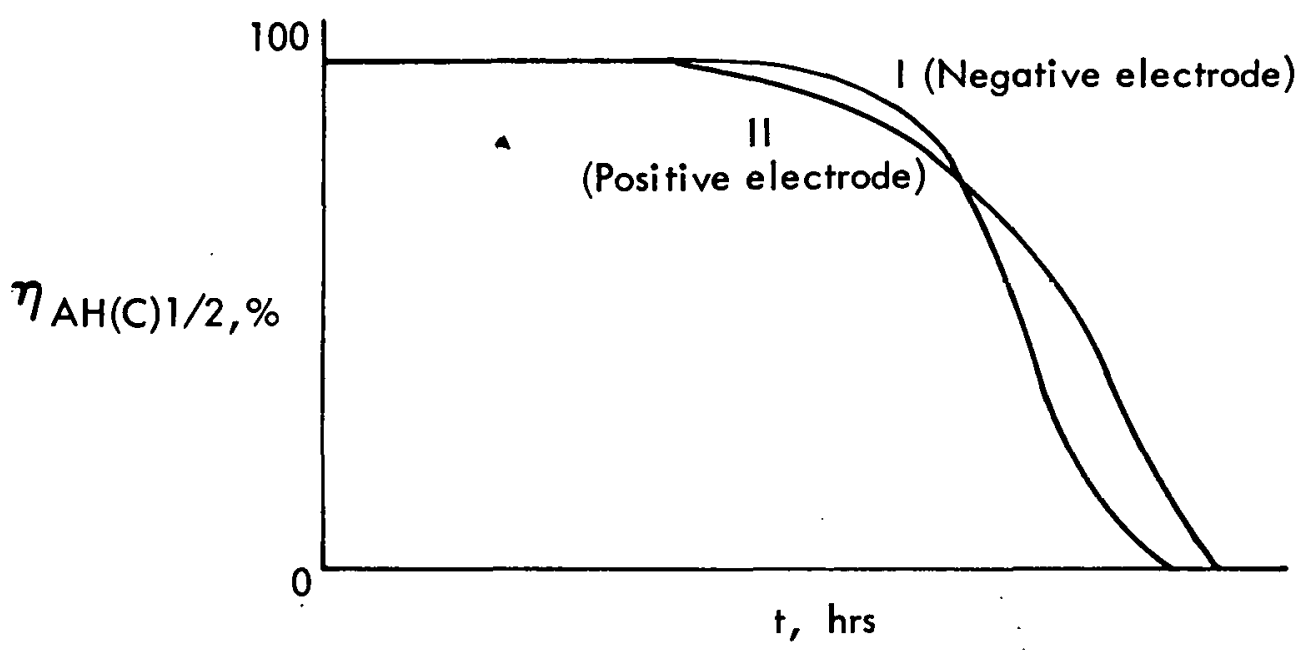

FIGURE 1 
Energy efficiency for the charging process can be calculated by using this information together with measurements of charge voltages as a function of time and open-circuit voltage readings at various times during charge.

The integrated energy, $\epsilon_{c}$, consumed on charge from time $t=0$ to time $t_{f}$ is given by:

$$
\epsilon_{c}=\int_{0}^{t_{f}} E_{c} I_{c} d t
$$

where $E_{C}$ is the charge voltage.

The theoretical minimum energy to accomplish the charging is: $\because$

$$
\because \cdots \epsilon_{c}(\min )=\int_{0}^{t_{f}} E^{O}\left(1_{c}-1_{g c}\right) d t
$$

where $E^{\circ}$ is the reversible potential.

and the half-cycle energy efficiency $\eta_{\epsilon(C) 1 / 2}$ for the charging process becomes:

$$
\eta_{\epsilon(c) 1 / 2}=\frac{\int_{0}^{t_{t}} E^{0}\left(I_{c}-I_{g c}\right) d t}{\int_{0}^{t_{f}} E_{c} I_{c} d t}
$$


Figure 2 shows the form of the half-cycle energy efficiency for the charging process.

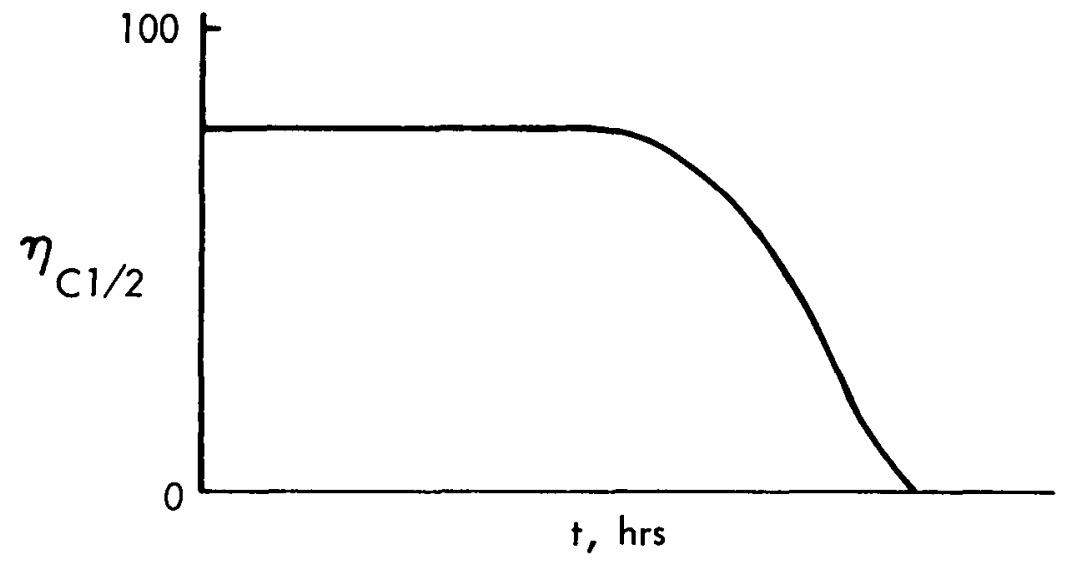

FIGURE 2

Figure 2 shows one curve. That represents the case in which only cell (or battery) voltages are measured. For these tests, 
the coulambic efficiency of the cell is taken to be the average efficiency for the two electrodes. If individual electrode potentials are measured, individual electrode energy efficiencies can be calculated.

A half-cycle discharge efficiency can be defined in a manner analogous to that for the charging process. The expression becomes:

$$
\eta_{(d) 1 / 2}=\frac{\int_{0}^{t_{f}} E_{d} I_{d} d t}{\int_{0}^{t_{f}} E^{O}\left(1_{d}-I_{g d}\right) d t}
$$

where d subscripts refer to dlscharge. Very little gassing occurs during discharge, so that $I_{d}$ is substantially equal to $I_{d}-I_{g d}$. This relation is widely used for the purpose of calculating half-cycle efficiencies for primary cells which never experience the charging half-cycle.

The theoretical minimum energy needed for charging, equation (12), is equal to the theoretical maximum energy which can be obtained on discharge - the denominator of equation (14). The product of the two half-cycle efficiencies becomes:

$$
\eta=\eta_{\cdot c 1 / 2 \times{ }_{d 1 / 2}}=\frac{\int_{0}^{t_{f}} E_{d} I_{d} d t}{\int_{0}^{t_{f}} E_{c} I_{c} d t}
$$

It is seen from equation (15) that the overall energy efficiency for a complete cycle reduces to the actual energy out divided by the actual energy in. 


\subsection{EXPERIMENT DESCRIPTION}

\subsection{Test Set Up}

Six EV-106 lead-acid traction batteries (manufactured by ESB Inc.) were used for the tests. Three were used immediately following preconditioning, and are referred to in this report as new batteries. Three were deep-cycled 200 times before testing and are referred to as aged batteries.

\subsection{1 "New" Batteries.}

The preconditioning was done as follows:

A. Each battery was discharged at 50 amps to 3.9 volts.

B. The three batteries were charged in series at 25 amps to 23.7 volts $(2.63 \mathrm{~V} /$ cell average $)$.

C. A and B were repeated twice more.

\subsection{2 "Aged" Batteries.}

The remaining three batteries were aged by the following procedure:

A. Each battery was charged to a 7.8 volt cutoff, changed to a 7.9 volt cutoff $(2.63 \mathrm{~V} /$ cell average $)$ at cycle $\$ 26$.

B. The three were discharged at 50 amps to 4.5 volts.

c. Every seven days, beginning with cycle $\$ 89$ and repeated for cycles 133, 155 and 177, each battery was charged at 25 amps to a 7.4 volt signal voltage. A timer was started which continued the charging at 25 amps for five hours, but with a limit of 8.1 volts.

D. The cycling was continued for a total of 200 cycles. 


\subsection{Charge Profiles}

Three different charging profiles were used in the testing program and are shown in Figure 3, Pg. 17.

Profile 1: Charge was at a constant current until a preselected voltage was reached, after which the voltage was maintained at a constant value (clamped). Charging was continued until gassing determinations indicated that complete gassing had occurred for those tests of: hälf-ryrle Heterminations.

Proflile 2: Charge was at a constant current untıl a preselected voltage (signal voltage) was reached, at which time the voltage was dropped to a lower voltage (clamping voltage) and continued at this level until complete gassing occurred.

Profile 3: Charge was at a constant current until a preselected voltage (signal voltage) was reached, at which time the current was dropped to a lower, constant value and maintained until conplete gassing occurred.

\subsection{Charge Procedures}

A charge procedure is a particular charge profile with specified values for the variables. In Table 1, Pg.16, three procedures are shown for each of three profiles.

The various charging tests are described as follows: 


\section{TEST A}

\section{HALF-CYCLE EFFICIENCIES OF NEW BATTERIES}

MEASUREMENTS

- Voltage

- Current

- Gassing rate, total

- Oxygen Concentration

- Time

- Electrolyte Temp.
CALCULATED VALUES

- Wh

- Ah

- Half-Cycle Efficiency

- Gassing rate, $\mathrm{H}_{2}$

- Power

- Gassing rate, $\mathrm{O}_{2}$

TEST METHOD

- Profiles 1, 2, \& 3 @ Procedures 1, 2, \& 3 (See Table 1).

- Charge to complete gassing.

- Discharge at constant current (25 amps). 
TABLE

CHARGE PROFILES \& PROCEDURES

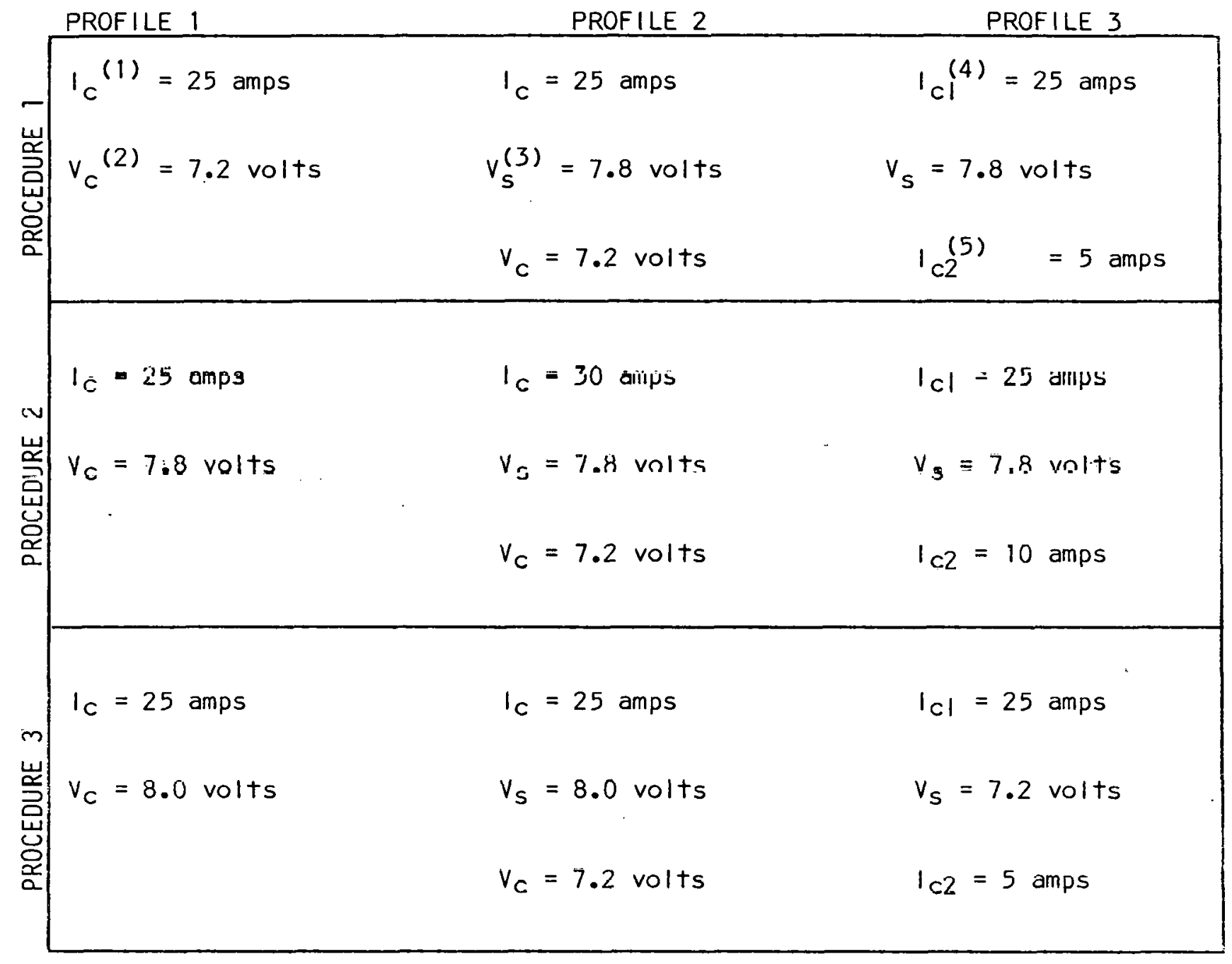

NOTES: (1) $\mathrm{l}_{\mathrm{c}}=$ Constant Current

(2) $v_{C}=$ Clamping Voltage

(3) $v_{s}=$ Signal Voltage

(4) $|\mathrm{c}|=|n i t i a|$ Constant Current

(5) $\mathrm{I}_{\mathrm{c} 2}=$ Final Constant Current 

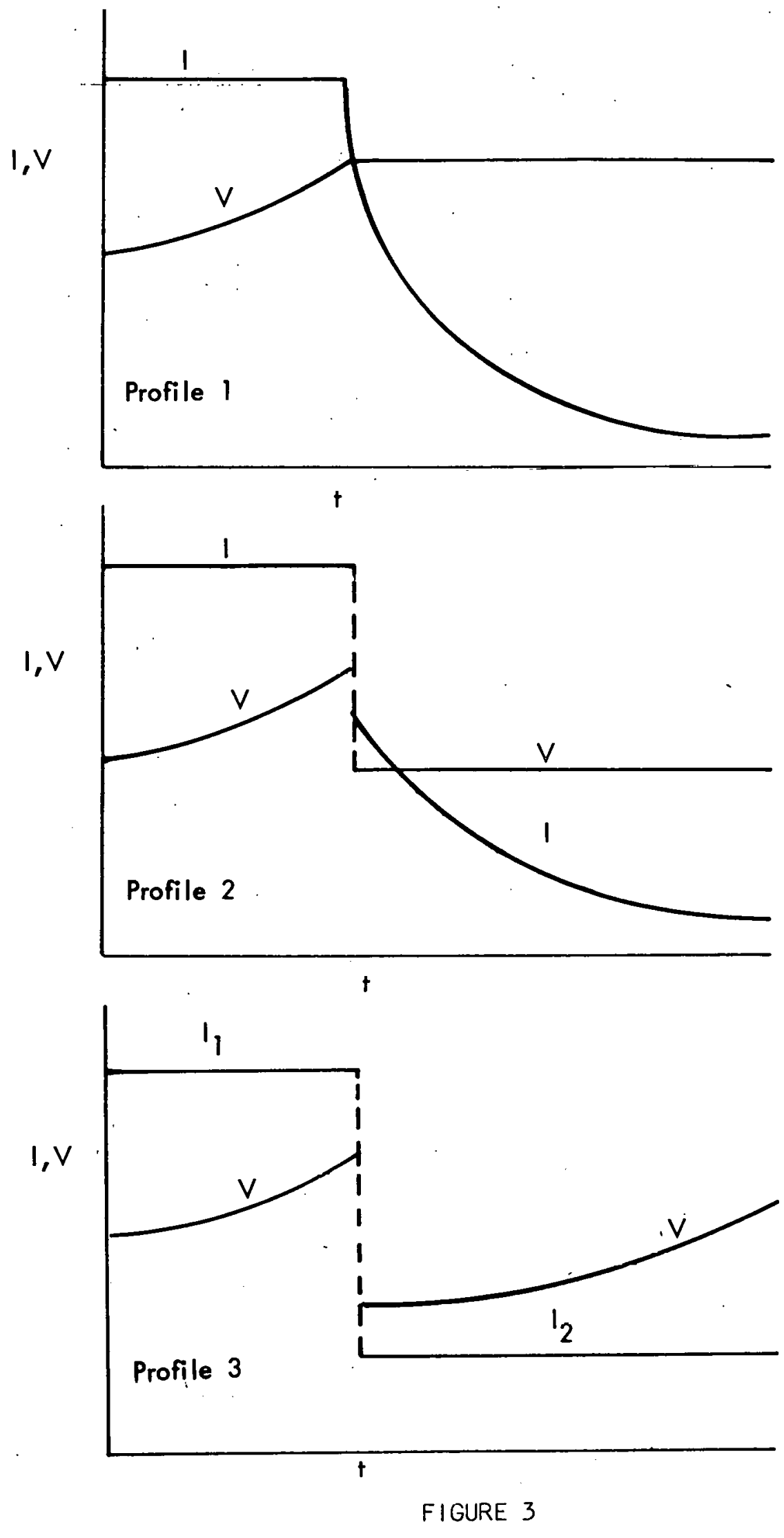

CHARGE PROFILES 


\section{FULL CYCLE EFFICIENCIES OF NEW BATTERIES}

\section{MEASUREMENTS AND CALCULATED VALUES}

- Same as Test A, except full-cycle efficiencies are calculated instead of half-cycle.

\section{TEST METHOD}

- Three profiles; procedures 1 \& 3 of each.

- Enarge orle liuul after rcuching elgnal voltaga for Prosedure 1

and for each Profile. Charge only to signal voltage for Procedure 3 for each Profile.

\section{TEST $\mathrm{C}-1$}

CHANGE OF BEHAVIOR WITH AGING

\section{MEASUREMENTS}

- Voltage

\section{TEST METHOD}

- Charge @ 25 amps to 7.9 volt cutoff.

- Discharge 巴 50 amps to 4.5 vult cutoff.

- Every seven days charge 25 amps to 7.4 volts. Start timer to run for five hours. Continue charge during this period with a limit of 8.1 volts.

- Repeat above procedures for a total of 200 cycles. 
TEST C-2

HALF-CYCLE \& FULL-CYCLE EFFICIENCIES

OF AGED BATTERIES

MEASUREMENTS \& CALCULATED VALUES

- Same as Tests A and B.

\section{TEST METHODS}

- Same as Test A except only Proflles 1 \& 2, and use aged batteries instead of new.

- Charge one hour after reaching signal voltage for Procedures 1 and 2 for each Profile. Charge only to signal voltage for Procedure 3 for each Profile.

- Temperature: $20^{\circ} \mathrm{C}$.

\section{$\underline{\text { TEST D }}$}

EFFECTS OF CHARGING IN SERIES, AGED BATTERIES

MEASUREMENTS \& CALCULATED VALUES

- Same as Test C-2

TEST METHOOS

- Same as Test C-2 


\section{TEST $E-1$}

\section{HALF-CYCLE \& FULL-CYCLE EFFICIENCIES}

\section{HIGH TEMPERATURE}

MEASUREMENTS \& CALCULATIONS

- Same as Test C-2

\section{TEST METHOOS}

- Lame as lest $C_{-2}$, excepl nuw hallen ies illsteád of aged.

- Temperature: $49^{\circ} \mathrm{C}$

\section{TEST $E-2$}

HALF-CYCLE \& FULL-CYCLE EFFICIENCIES

\section{LOW TEMPERATURE}

MEASUREMENTS \& CALCULATIONS

- Same as Test C-2

\section{TEST METHODS}

- Same as Test C-2, except new batteries instead of aged.

- Temperature: $0^{\circ} \mathrm{C}$ 


\subsection{Discharge Procedures}

A single discharge procedure was used following each charge. The procedure was a constant current discharge at 50 amps to a 3.9 volt cutoff, after a one-hour rest period beginning at the end of charge. All discharges were done at $20^{\circ} \mathrm{C}$, regardless of the temperature during charge. A 24 -hour soak at $20^{\circ} \mathrm{C}$ preceded the discharge whenever the charge was not done at $20^{\circ} \mathrm{C}$.

\subsection{Temperature}

Ambient temperature was controlled at three levels: $0^{\circ} \mathrm{C}$, $20^{\circ} \mathrm{C}$, and $49^{\circ} \mathrm{C}$, with a tolerance of $\pm 1^{\circ} \mathrm{C}$. Whenever the charge temperature was different from $20^{\circ} \mathrm{C}$, a 24 -hour soak at the charging temperature preceded the charge:

\subsection{EXPERIMENT DESCRIPTION, ENERGY EFFICIENCY TESTS}

In order to get information on the energy efficiency during the charging cycle, some tests were run in which charge voltages were measured as a function of state of charge. Voltage efficiency is calculated by dividing open-circuit voltage for that state of charge by the charge voltage. This voltage efficiency is then multiplied by the instantaneous current efficiency at that state of charge to give the instantaneous charging energy efficiency.

In order to know the true (reversible) open-circuit voltage of the battery, each of the three new batterles was fully charged and allowed to stand for 24 hours. The open-circuit voltages were recorded, the batteries were discharged at 25 amps for one hour, and again allowed to stand for 24 hours. The process was repeated until the batteries 
would no longer discharge for one hour at 25 amps. These data points generated a curve for each battery which was used in making the energy efficiency calculations.

\subsection{MEASUREMENTS}

Measurements of battery voltage, current, total gas flow rates and oxygen concentration in the evolved gasses were made as described below. Battery voltage and current were recorded continuously on charge and discharge. Oxygen concentration was monitored continuously during charge, and total gas flow rates were determined and recorded manually every half hour during charge. In addition, specific gravities of each cell were measured manually and recorded. Center cell temperatures were also recorded.

\subsection{Voltage}

Battery voltage was measured and recorded at the beginning of charge and discharge. It was also recorded after every change of $20 \mathrm{mv}$ throughout the charge and discharge procedures, and measured every 30 seconds.

\subsection{Current}

Current was measured and recorded coincidently with voltage measurements.

\subsection{Gas Flow Rates}

Measurements of the total gas flow rates were inade with the positive displacement apparatus devised in our laboratory. The apparatus is shown in Figure 4 .

In operation, valve $B$ is opened to allow water from the reservoir to enter the measuring tube. (The tube does not have to be filled, but some water must be present). In making the measurenent, 


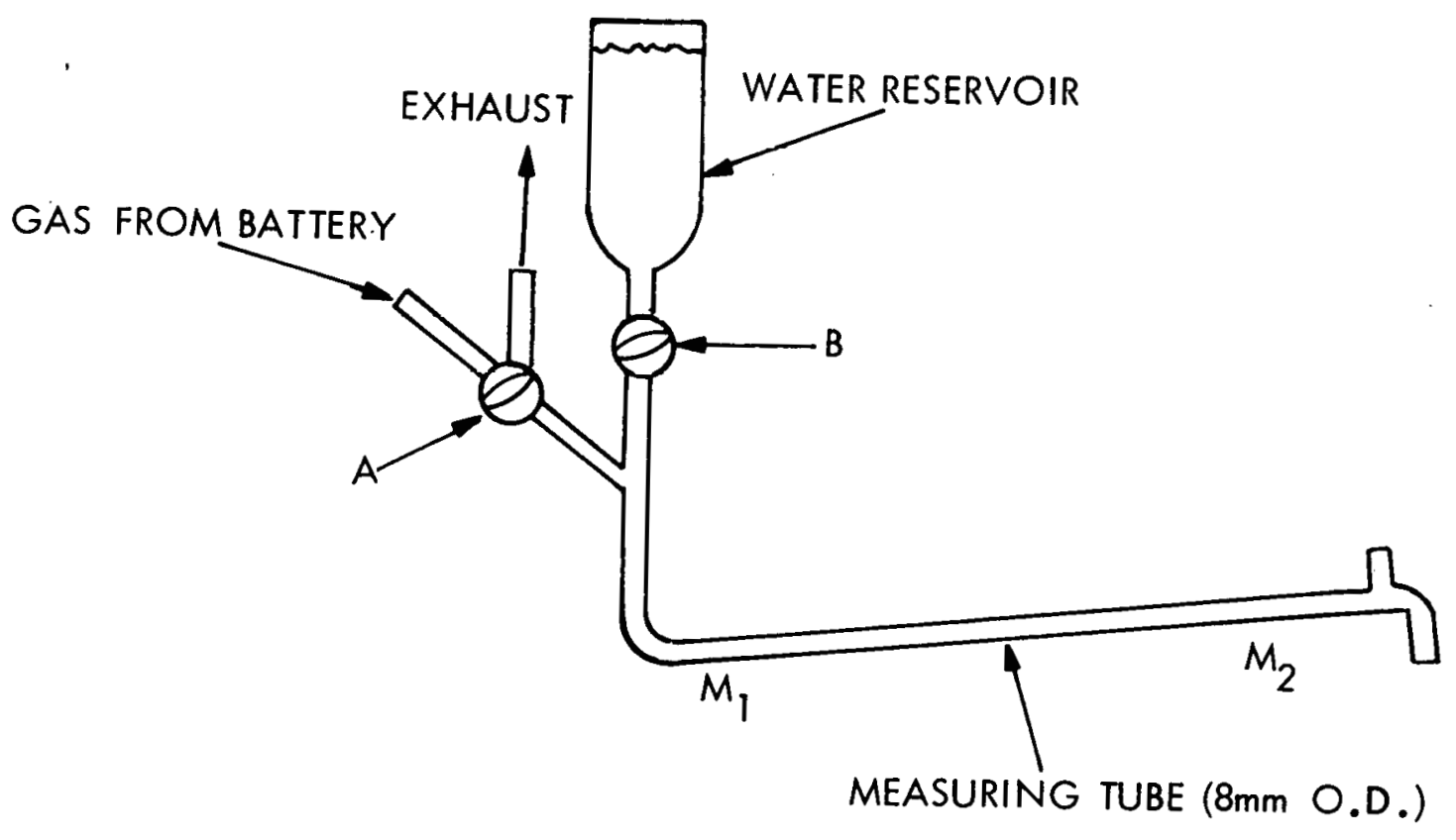

FIGURE 4

GAS FLOW METER 
the two-way valve $(A)$ is turned to admit gas from the battery into the measuring tube. The time of passage of the trailing meniscus of the water from Mark $M_{1}$ to mark $M_{2}$ is measured with a stop watch. The volume of water contained between those marks is determined by weighing the water contained between them. At the end of each measurement, valve $A$ is turned to exhaust the gas from the battery into the hood, and valve $B$ is opened momentarily to admit water from the reservoir for the next measurement. Although this measuring device is manually operated, it is capable of high accuracy and can be used as a primary standard by which electronic or other types of gas flow meters may be calibrated.

\subsection{Oxygen Flow Rates}

Oxygen flow rates were determined from the total gas flow rates and the oxygen concentration in the gas stream. The latter was measured with a Beckman Field Lab 1008 Oxygen Analyzer.

\subsection{Hydrogen Flow Rates}

Hydrogen flow rates were deterinined by the ditterence between the total flow rates and oxygen flow rates.

\subsection{TEST OUTLINE}

All of the tests are summarized in Table 11 . It is seen that 39 tests were required, not counting the age-cycling of Test $\mathrm{C}-1$. Each of those tests required one working day. Test C-1 ran continuously, automatically, and in parallel with the other tests. 


\subsection{RESULTS}

The test results are shown in Appendixes $A$ through $E$ and in Tables III and IV. Appendix A shows the results of the coulombic charging efficiency tests, Appendix B shows selected cycles of the aging tests, Appendix $C$ shows the results of the energy efficiency tests, and Appendix D shows the reversible open-circuit voltages as a function of state of charge for each of the new batteries.

An error analysis was made to cvaluate the accuracy of a coulometric state-of-charge indicator corrected for charging inefficiencies as determined by our gassing measurements. Appendix E shows the results.

\subsection{OBSERVATIONS AND CONCLUSIONS}

There are some general observations which can be made, from which a few conclusions are drawn. Some of these might be called "hard" conclusions, while others are "softer" or still tentative at this time.

\subsection{General Observations}

As the batteries are charged, gassing is always first evidenced at the positive plates, as can be seen in the graphs in Appendix A. Note that half-cycle coulombic charging efficiency falls below $100 \%$ at the positive plates first. This is not a new observation and is in the existing literature. The departure is not large, and the curves soon cross. The argument was made earlier (Secton 3) that, over several complete cycles, the mean charging efficiencies will be approximately equal. 
TABLE 11

SUMMARY OF TESTS

\begin{tabular}{|c|c|c|c|}
\hline TEST & $\begin{array}{l}\text { NO. } \\
\text { OF } \\
\text { EXPTS. }\end{array}$ & PURPOSE & DESCRIPTION \\
\hline$A$ & 17 & $\begin{array}{l}\text { Half-Cycle Efficiencies } \\
\text { of New Batteries }\end{array}$ & $\begin{array}{l}3 \text { Procedures, } \\
3 \text { Profiles } \\
\text {, }\end{array}$ \\
\hline$B$ & 14 & $\begin{array}{l}\text { Full-Cycle Efficiencies } \\
\text { of New Batteries }\end{array}$ & 3 Procedures, \\
\hline $\begin{array}{r}C-1 \\
\quad \therefore\end{array}$ & - & $\begin{array}{l}\text { Change of Behavior with } \\
\text { Aging }\end{array}$ & $\begin{array}{l}\text { Const. Daily } \\
\text { Charging + Periodic } \\
\text { Full Charging }\end{array}$ \\
\hline$C-2$ & 36 & $\begin{array}{l}\text { Half-Cycle \& Full-Cycle } \\
\text { Efficiencies of Aged } \\
\text { Batterles }\end{array}$ & $\begin{array}{l}3 \text { Procedures, } \\
2 \text { Profiles }\end{array}$ \\
\hline$D$ & 18 & $\begin{array}{l}\text { Effects of Charging in } \\
\text { Series-Aged Batterles }\end{array}$ & $\begin{array}{l}3 \text { Procedures, } \\
2 \text { Profiles }\end{array}$ \\
\hline$E-1$ & 18 & $\begin{array}{l}\text { Half-Cycle \& Full-Cycle } \\
\text { Efficiencies; High Temp- } \\
\text { erature }\end{array}$ & $\begin{array}{l}3 \text { Procedures, } \\
2 \text { Profiles }\end{array}$ \\
\hline$E-2$ & 18 & $\begin{array}{l}\text { Half-Cycle \& Full-Cycle } \\
\text { Efficiencies; Low Temp- } \\
\text { erature }\end{array}$ & $\begin{array}{l}3 \text { Procedures } \\
2 \text { Profiles }\end{array}$ \\
\hline$A(E)$ & 17 & $\begin{array}{l}\text { Half-Cycle Energy Effi-. } \\
\text { ciencies of New Batteries }\end{array}$ & $\begin{array}{l}3 \text { Procedures, } \\
3 \text { Profiles }\end{array}$ \\
\hline$B(E)$ & 14 & $\begin{array}{l}\text { Full-Cycle Energy Effi- } \\
\text { ciencies of New Batteries }\end{array}$ & $\begin{array}{l}3 \text { Procedures, } \\
3 \text { Profiles }\end{array}$ \\
\hline$E\}(E)$ & 18 & $\begin{array}{l}\text { Half-Cycle \& Full-Cycle } \\
\text { Energy Efficiencies; High } \\
\text { Temperature }\end{array}$ & $\begin{array}{l}3 \text { Procedures, } \\
2 \text { Profiles }\end{array}$ \\
\hline$E 2(E)$ & 18 & $\begin{array}{l}\text { Half-Cycle \& Full-Cycle } \\
\text { Energy Efficiencies; Low } \\
\text { Temperature }\end{array}$ & $\begin{array}{l}3 \text { Procedures, } \\
2 \text { Profiles }\end{array}$ \\
\hline
\end{tabular}


An interesting feature of many of the experiments is the break in the efficiency curves which, in most cases, corresponds to the beginning of the current taper. But there are a few examples (e.g., graph 2) in which the break occurs decidedly before the onset of the current taper. An examination of the raw data shows that it is always associated with the battery voltage, going through a range of about 7.3 to 7.7 volts, The oxygen flow rate first reaches a maximum (minimum point on the efficiency curve) at 7.3 volts, followed by a minimum around 7.7 volts, above which the flow rate increases again.

The three procedures of Profile 1 differ only in clamping voltage values: $7.2,7.8$, and 8.0 volts for Procedures 1, 2, and 3, respectively (see Table 1). Based on the evidence presented here, it would appear that the lower the clamping voltage, the more amp-hrs that can be charged into the battery. This is seen in graphs 1, 2, and 3 . A different battery was used in each case, but their charge acceptances appear quite similar, as can be seen by comparing graphs 5,6 , and 7 where all three batteries go through the same procedure. Another point to note is that the inflections in the curves precede the beginning of current taper in Procedures 2 and 3 (more so in 3 than in 2), but they lag the current taper in Procedure 1. This is because the voltage clamp is lowest in Procedure 1 and, in fact, the voltage hardly gets into the region where there is a drop in oxygen evolution.

The three procedures of Hroflle 2 difter in both clamping current and signal voltage. A comparison of two current levels can be made from graphs 4 and 5. The 30-amp charge shown in graph 5 yielded slightly higher overall efficiencies than the 25-amp charge shown in graph 4. Graphs 4 and 8 compare clamping voltages. The comparison is incon- 
clusive since 7.8 volts, the clamping voltage of graph 4 , was exceeded by 8.0 volts in graph 8 . The initial drop in efficiency in the former should have been seen in the latter but was not present. The three procedures of Profile 3 differ in both signal voltage and clamping current. Procedure 1 differs from 2 in the final clamping current, and 1 differs from 3 in signal voltage. Procedure 1, with a 5-amp final clamping current, shows the highest efficiencies to $200 \mathrm{Ah}$ (Graphs 9, 10 and 11). A change in signal voltage (Graphs 15, 16 and 17) did not substantially change things, but increasing the clamping current to 10 amps caused a very rapid drop in efficiency as soon as the initial clamping current was changed. See especially graph 13.

An examination of the capacity and efficiency columns in Table III shows that the procedures of Profile 3 give the best combination of those two characteristics. This is especially true of Procedure 3 of Profile 3, probably because higher efficiencies appear to result from lower currents when the battery approaches full charge. It does so, however, at the expense of a longer recharge time than is found for Profiles 1 and 2. 
The procedures and profiles of Test B are the same as for Test A, except that charging was terminated earlier, as discussed in Section 4.3. They were done for the purpose of getting additional information for state-of-charge evaluation. Since charging was terminated early, predictions could be made for the capacity delivered on subsequent discharge, then verified by measuring the discharge capacity.

The effects of aging (200 cycles at $100 \%$ DOD) can be seen in the graphs of Test C2. Graphs 32 through 37 show the three batteries being charged by Procedure 1 of Profile 1. Graphs 33, 35 and 37 show continuations, the following morning, of the charging experiments to see what happens during extended overcharge. Several characteristics of the aged batteries are quite evident. First, two of the three batteries accepted much less of a charge than the new battery charged in the same manner (Graph 1), while battery $\$ 2 D$ accepted a charge just about as well. Examination of graphs 41 through 46 show that, in most cases, ne'gative plate efficiencies are noticeably lower than those of the positive plates. But there is only one comparison for these charge procedures (Profile 1, Procedure 2) with a new battery and that is shown in graph 2 . 
That battery also showed a lower negative plate efficiency. Relative efficiencies of positive and negative plates are difficult to define because of the arguments made in Section 3. The plates with the higher efficiencies on the initial cycle will be in a higher state of charge on the next cycle and will begin to gas earlier. The question of gassing as a function of electrode potential was not resolved by these experiments, since no reference electrodes were used.

The graphs in Test D show very good matching between the three batterles in the series tests. All batteries were made to take the same current. Ine charge accepldice was yemerally good, and no single battery showed a disproportionate amount of gassing.

The high temperature tests of Experiment El show a much longer time that the batteries will accept charge for a given efficiency (e.g., Graph 89 vs. Graph 18). The reverse is true at low temperature, but the effect is largely confined to the negative electrode (Graphs 110115 and 122-124). The interesting information gained from experiments E1 and E2 is that higher temperatures are conducive to greater charge acceptance and the results were quantifled. Thus, it can be seen by comparing Graph 89 with Graph 18 that $11 \%$ more charge is accepted above 90\% coulombic efficiency. A full charge is attained in any case when all of the $\mathrm{PbSO}_{4}$ at each electrode is converted to lead metal or $\mathrm{PbO}_{2}$, but more time-consuming procedures are required at lower temperatures to accomplish what can easily be done at higher temperatures. 
Appendix B shows 14 selected charges and discharges for the age cycling. The recording began with a discharge cycle. Corresponding cycle numbers are shown except in the four cases of equalization charging, which occurred at charge cycles $89,133,155$, and 177 . In those cases the subsequent discharge cycles $(90,134,156$, and 178) are shown since we needed to know the benefit in capacity for equalization.

The importance of conditioning cycling before running any capacity tests is shown by comparing discharge cycles 1, 5, and 10. The average capacities increased by $29 \%$, when measured to 4.5 volts. A comparison between the pairs of discharge cycles 70 and 90,130 and 134, 150 and 156, and 175 and 178 shows an increase of 20,23, 21, and 27 percent, respectively, which is due to equalization charging over the charge procedure used for all but four of the 200 cycles in the age cycling. But the charging procedure used for those 196 cycles was very easy on the batteries and yielded typical amp-hr efficiencies of 97 to $99 \%$. The loss in capacity for the age cycling was quite different from one battery to another. This fact may reflect on the quality control during production. Between cycle 30, when the batteries were fully conditioned and were always being charged to a 7.9 volt cutoff, and cycle 195, battery $\# 10$ increacen in capacity by $17 \%$, bottery $\# 20$ increased by $22 \%$, while battery $\# 30$ decreased by $21 \%$. A comparison of the charging curves, however, shows some effects of aging. Battery \#2D appears to show the effects of antimony transfer to the negative plates. Note that the charging efficiency is way down, even though the total charge acceptance is up. 
An examination of the energy efficiency curves in Appendix C shows that energy efficiency during charge stays above 90 percent for about the first 125Ah for almost all charge procedures (except the low temperature ones). At $120^{\circ} \mathrm{F}$ they hold $90 \%$ energy efficiency for about $150 \mathrm{Ah}$ and, as it is at $75^{\circ} \mathrm{F}$, the amount of capacity above $90 \%$ energy efficiency seems quite insensitive to the charging procedure for the procedures examined here. At $32^{\circ} \mathrm{F}$, on the other hand, energy efficiencies are always below $90 \%$ and the capacity above $80 \%$ does vary somewhat with the charge procedure.

Appendix $E$ shows the results of an error analysis for all tests. Figure 3 plots percentage of error versus frequency for the 124 experiments. Error is defined as the predicted discharge capacity, in which the prediction is equal to the charge applied corrected for the inefficiency as determined by gassing measurements, subtracted from the measured discharge capacity. Thus a positive error means the capacity is more than predicted, and vice versa. For the predicted discharge capacities the average efficiencies for the two electrodes was used for the corrections. Table 111 summarizes the results shown in the graph.

The reasons for the large errors in a few cases are not always known. The biggest error was on the weak battery in a series test. The two other batteries in series with it had positive errors of $6.7 \%$ and $6.6 \%$. It was driven (probably in reverse) by the other batteries. This fact points out the importance of monitoring several batteries in a pack, and also the importance of fault detectors for individual batteries. This becomes especially important with aged batteries, which these were. The second biggest error (29.3\%) followed 
immediately after a run in which that battery had shown the biggest negative error of the tests $(-15.0 \%)$. There was, for some reason, a residual capacity which should have come out on that cycle but did not. The largest errors are apparently caused by inaccuracies in measurements of time in the gas flow meters at very high flow rates. These flow rates occur near the end of the charge and eventually require accurate measurements of less than one full second. An examination of the raw data shows that, in some cases, the gas flow rate measurements are higher than the theoretical by an amount which would cause positive errors of several percent. Large negative errors might result from the same source but it would be more difficult to prove. It is easier to prove that the flow rate measurement is in error when it indicates rates which are impossible for the current flowing at that time.

\subsection{Definite Conclusions}

1. Energy efficiencies in excess of $90 \%$ are exhibited to about 125Ah for the ESB EV-106 battery for all charge procedures at room temperature. This point on the capacity curve is extended to about $150 \mathrm{Ah}$ at $120^{\circ} \mathrm{F}$. At $32^{\circ} \mathrm{F}$ it is usually less than 100Ah, and seems to be somewhat more dependent upon the charge procedure.

2. The constant-current charge procedure to a cutoff voltage allowed 200 cycles to be run on this battery at $100 \%$ D00 with very little degradation. In fact, a capacity increase was observed on two of the batteries. This charge procedure gave inore than $80 \%$ of the capacity provided by the more extensive equalization charge. 
3. Higher temperatures increase charging efficiencies and lower temperatures decrease them.

4. A state-of-charge indicator based on the gas-measurement, modified coulometer should be an accurate, reliable indication of state of charge, provided that it can be reset at intervals of no more than a few cycles.

\subsection{Tentative Conclusions}

1. Positive electrodes exhibit an (apparent) increase in coulometric efficiency while passing through the voltage range nf 7.3 tn 7.7 volts. 2. Coulomblc efficiencies during charye are relatively insensitive to the charging procedure for the nine different procedures studied here, provided that charging is terminated as soon as gassing reaches $100 \%$ of total current

3. When a charge is taken to a clamping voltage, it appears that a greater capacity can be charged when the clamping voltage is lower. But the effect is small, and total charge, in addition to mean coulombic efficiencies, are not very sensitive to the charge procedure.

4. Negative plate coulombic efficiencies appear to be lower than positive plate coulombic efficiencies for the aged batteries. This is to be expected because of the antimony transfer with cycling. 5. When the three aged batteries were charged in series, the charge acceptance for the three showed very good matching in most cases. 


\subsection{RECOMMENDATIONS}

Recommendations can be made for both charging and measuring the state of charge of lead-acid batteries based on the observations and conclusions presented in Section 9. It should be borne in mind, however, that charge acceptance characteristics of lead-acid batteries may vary significantly from one manufacturer to another, or among different models by a given manufacturer. All of the tests described in this report refer to the ESB EV-106 battery. The actual values of key parameters (e.g., voltage, current) should be determined for a given battery for optimum charging profiles, but otherwise the recommendations are general for lead-acid batteries.

\subsection{Charging Recommendations}

Based on the charge procedures studied in this program, it is recommended that an ESB EV-106 battery be charged at 25 amps to a signal voltage of 7.2 volts, after which the current is stepped down to 5 amps. This latter current should be maintained to the point of complete gassing (i.e., to the point of zero efficiency) if instrumentation is available to ascertain this point. Since this type of instrumentation is rarely available, charging can be timed for a period of six hours from the time the signal voltage is reached. These tests have shown that this two-step profile consistently yields a combination of highest efficiency and greatest capacity. This type of charging should be used prior to capacity tests, and at least periodically (about every 10 cycles) to reduce sulfatation at the negative plates. An alternative procedure, which may be used for a daily charge whenever maximum capacity is not needed, is to charge at 25 amps 
to a signal voltage of 7.2 volts and then. stop. This procedure yields even higher efficiencies (both coulombic and energy), and reduces charging time for a fully discharged battery from 12-13 hours to 6-7 hours.

\subsection{State-of-Charge Indicator}

State-of-charge indication can be accurately and reliably monitored by the modified coulometer method. During the charging cycle, the amp-hours charged into the battery must be modified by the inefficioncloc as dotorminad by the gaseas evelved. Continums deterini= nations of gas evolution rates and hydrogen and/or oxygen concentrations are necessary to correct the coulometer. It would be desirable to have a reset mechanism for the coulometer in order to prevent drift. This subject will be addressed in the FY'80 program. 


\begin{tabular}{|c|c|c|c|c|c|c|c|c|c|}
\hline $\begin{array}{c}\text { TEST } \\
\text { NUMBER } \\
\end{array}$ & $\begin{array}{l}\text { TEST } \\
\text { TYPE } \\
\end{array}$ & $\begin{array}{l}\text { BATTERY } \\
\text { NUMBER } \\
\end{array}$ & PROF ILE & PROCEDURE & $\begin{array}{l}\text { TEMP. } \\
{ }^{\circ} \mathrm{C} \\
\end{array}$ & $\begin{array}{l}\text { CURRENT } \\
\text { TAPER PT. } \\
\text { AH } \\
\end{array}$ & $\begin{array}{c}\text { CHARGE } \\
\text { TIME } \\
\text { HRS } \\
\end{array}$ & $\begin{array}{l}\text { CAPA- } \\
\text { CITY } \\
\end{array}$ & $\begin{array}{l}\text { HALF-CYCLE } \\
\text { COULCMBIC } \\
\text { EFFIC IENCY } \\
\frac{\%}{8} \\
\end{array}$ \\
\hline 1 & $A$ & $2 \mathrm{~L}$ & 1 & 1 & 20 & 153 & 9.50 & 168.6 & 97.2 \\
\hline 2 & $"$ & $1 \mathrm{~L}$ & 1 & 2 & 20 & 162.5 & 7.92 & 167.8 & 79.7 \\
\hline 3 & $"$ & $3 L$ & 1 & -3 & 20 & 184.25 & 7.37 & 165.7 & 83.4 \\
\hline 4 & $"$ & $1 \mathrm{~L}$ & 2 & 1 & 20 & 170 & 9.13 & 169.8 & 90.2 \\
\hline 5 & $"$ & $1 \mathrm{~L}$ & 2 & 2 & 20 & 168.94 & 8.50 & 173.2 & 94.1 \\
\hline 6 & $"$ & $2 \mathrm{~L}$ & 2 & 2 & 20 & 175.42 & 8.50 & 175.6 & 94.8 \\
\hline$\ddot{\omega}$ & $"$ & $3 L$ & 2 & 2 & 20 & 165.95 & 8.50 & 167.8 & 94.6 \\
\hline 8 & $"$ & $3 L$ & 2 & 3 & 20 & 195.8 & 7.78 & 167.4 & 83.0 \\
\hline 9 & $"$ & IL & 3 & 1 & 20 & 183 & 11.35 & 186.2 & 91.7 \\
\hline 10 & $"$ & $2 L$ & 3 & 1 & 20 & 189.25 & 11.35 & 189.8 & 91.4 \\
\hline 11 & $"$ & $3 L$ & 3 & 1 & 20 & 176.5 & 11.35 & 174.3 & 91.0 \\
\hline 12 & $" 1$ & IL & 3 & 2 & 20 & 185 & 11.25 & 189.1 & 84.9 \\
\hline 13 & " & $2 \mathrm{~L}$ & 3 & 2 & 20 & 189.25 & 11.25 & 191.4 & 84.7 \\
\hline 14 & $" 4$ & $3 L$ & 3 & 2 & 20 & 169.5 & 11.25 & 175.6 & 82.1 \\
\hline 15 & $"$ & 11 & 3 & 3 & 20 & 161.75 & 12.52 & 183.0 & 95.9 \\
\hline 15 & $"$ & $2 L$ & 3 & 3 & 20 & 161 & 12.51 & 186.4 & 96.1 \\
\hline 17 & $"$ & $3 \mathrm{~L}$ & 3 & 3 & 20 & 151.25 & 12.51 & 163.4 & 95.9 \\
\hline 13 & $"$ & IL & 3 & 1. & 20 & 153.75 & & & \\
\hline
\end{tabular}


SIJMAARY OF COULOMBIC EFFICIENCY TESTS

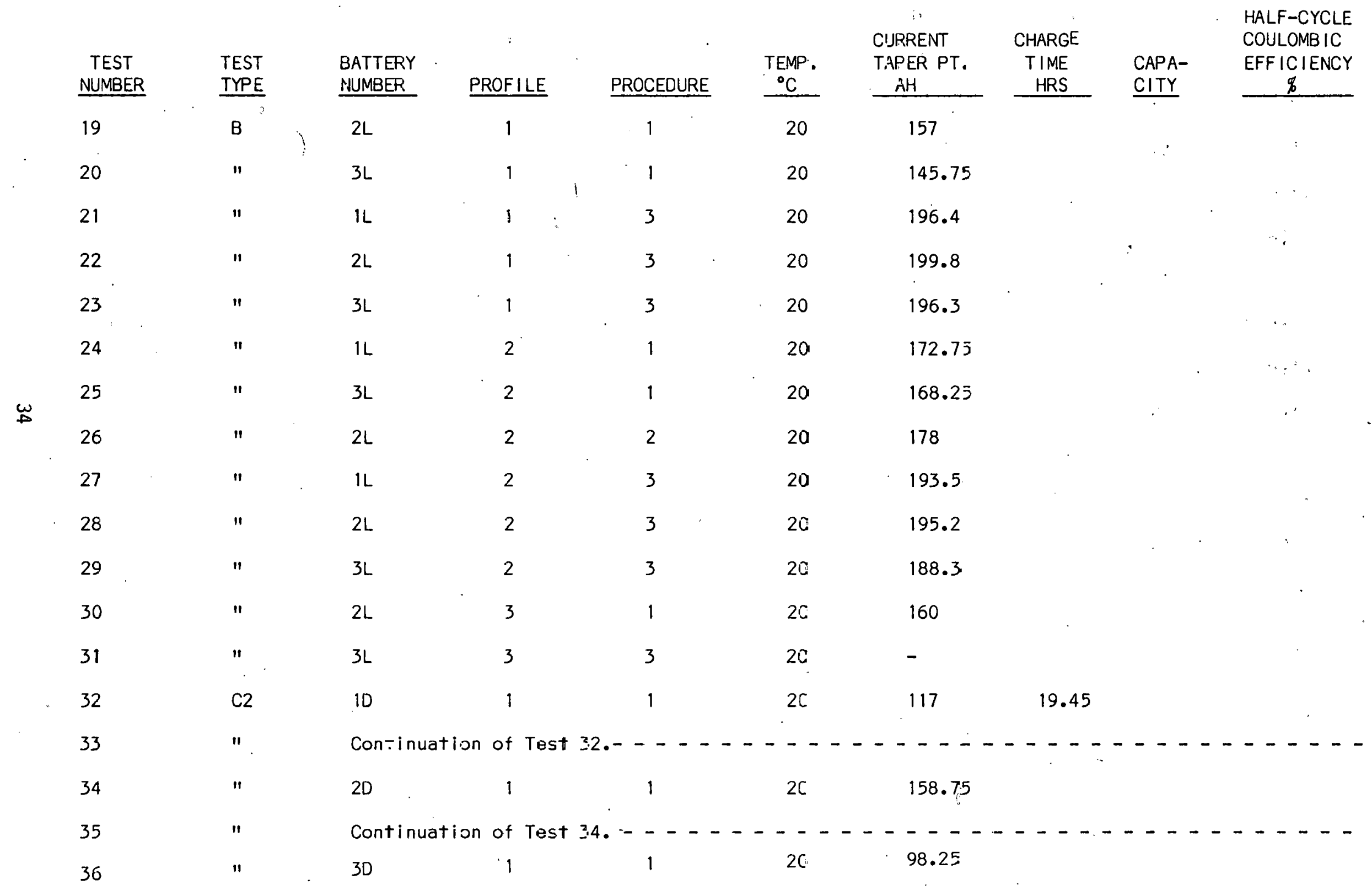


SUMMARY OF COULOMBIC EFFICIENCY TESTS

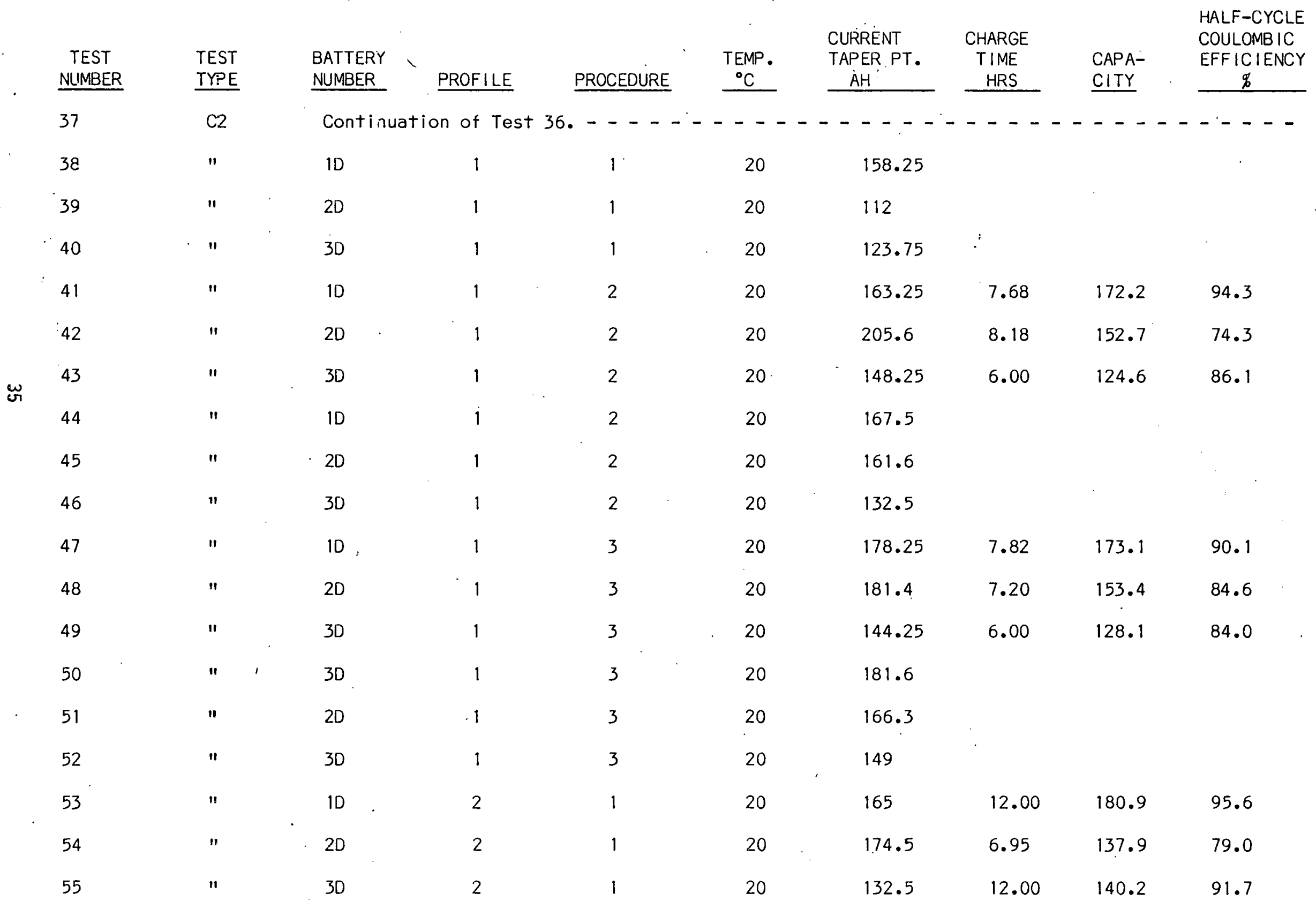


SUMM:ARY OF COULOMBIC EFFICIENCY TESTS

\begin{tabular}{|c|c|c|c|c|c|c|c|c|c|}
\hline $\begin{array}{c}\text { TEST } \\
\text { NUMBER } \\
\end{array}$ & $\begin{array}{l}\text { TEST } \\
\text { TYPE } \\
\end{array}$ & $\begin{array}{l}\text { BATTER } \\
\text { NUMBER } \\
\end{array}$ & PROFILE & PROCEDURE & $\begin{array}{l}\text { TEMP. } \\
{ }^{\mathbf{c}} \mathrm{C} \\
\end{array}$ & $\begin{array}{l}\text { CURRENT } \\
\text { TAFER PT. } \\
\text { f.t. }\end{array}$ & $\begin{array}{c}\text { 2HARGE } \\
\text { TIME } \\
\text { HRS } \\
\end{array}$ & $\begin{array}{l}\text { CAPA- } \\
\text { CITY }\end{array}$ & $\begin{array}{l}\text { HALF-CYCLE } \\
\text { COULOMBIC } \\
\text { EFFICIENCY } \\
\frac{\phi}{8} \\
\end{array}$ \\
\hline 56 & $\mathrm{C} 2$ & 10 & 2 & 1 & 20 & 163 & & & \\
\hline 57 & $"$ & 20 & 2 & 1 & 20 & 63.9 & & & $\cdot$ \\
\hline $58^{\circ}$ & $"$ & $\geq 0$ & 2 & 1 & 20 & 30.5 & & & \\
\hline 59 & $"$ & $1 D$ & 2 & 2 & 20 & 163.55 & 11.42 & 181.9 & 95.8 \\
\hline 60 & $"$ & 20 & 2 & 2 & 20 & 139.5 & 11.42 & 140.2 & 83.2 \\
\hline 61 & $"$ & 30 & 2 & 2 & 20 & 109.5 & 11.42 & 140.6 & 90.9 \\
\hline 62 & $"$ & $1 D$ & 2 & 2 & 20 & 129.5 & & & \\
\hline 63 & $"$ & $2 D$ & 2 & 2 & 20 & $\$ 14.5$ & & & \\
\hline 64 & $"$ & 30 & 2 & 2 & 20 & 128.75 & & & \\
\hline 65 & $"$ & 10 & 2 & 3 & 20 & 178.5 & 11.70 & 179.7 & 92.3 \\
\hline 66 & " & $2 D$ & 2 & 3 & 20 & 156.6 & 6.24 & 113.8 & 72.7 \\
\hline 67 & $"$ & $3 D$ & 2 & 3 & 20 & 159.9 & 6.37 & 130.5 & 81.6 \\
\hline 68 & $"$ & $1 D$ & 2 & 3 & 20 & 170 & & & \\
\hline$\checkmark 69$ & $"$ & $2 D$ & 2 & 3 & 20 & 162.7 & & & \\
\hline 70 & " & 30 & 2 & 3 & 20 & 139.6 & & & \\
\hline 71 & D & 10 & 1 & 1 & 20 & 117 & & & 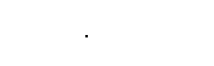 \\
\hline 72 & $"$ & 20 & 1 & 1 & 20 & 117 & & $\therefore$ & . \\
\hline 73 & $"$ & 30 & 1 & 1 & 20 & 117 & & & \\
\hline 74 & $"$ & 10 & 1 & $\tilde{z}$ & 20 & 155 & & & \\
\hline
\end{tabular}


SUMMARY OF COULOMBIC EFFICIENCY TESTS

\begin{tabular}{|c|c|c|c|c|c|c|c|c|c|}
\hline $\begin{array}{c}\text { TEST } \\
\text { NUMBER } \\
\end{array}$ & $\begin{array}{l}\text { TEST } \\
\text { TYPE } \\
\end{array}$ & $\begin{array}{l}\text { BATTERY } \\
\text { NUMBER } \\
\end{array}$ & PROFILE & PROCEDURE & $\begin{array}{l}\text { TEMP. } \\
\text { 员 } \\
\end{array}$ & $\begin{array}{l}\text { CURRENT } \\
\text { TAPER PT. } \\
\text { AH } \\
\end{array}$ & $\begin{array}{c}\text { CHARGE } \\
\text { TIME } \\
\text { HRS } \\
\end{array}$ & $\begin{array}{l}\text { CAPA- } \\
\text { CITY }\end{array}$ & $\begin{array}{l}\text { HALF-CYCLE } \\
\text { COULOMBIC } \\
\text { EFFICIENCY } \\
\frac{\%}{} \\
\end{array}$ \\
\hline 75 & D & $2 \mathrm{D}$ & 1 & 2 & 20 & 155 & & & \\
\hline 76 & $"$ & $3 D$ & 1 & 3 & 20 & 155 & & & \\
\hline 77. & $"$ & 10 & 1 & 3 & 20 & 178.6 & & & \\
\hline 78 & $"$ & $2 \mathrm{D}$ & 1 & 3 & 20 & 178.5 & & & \\
\hline 79. & $"$ & 30 & 1 & 3 & 20 & 178.6 & & & \\
\hline 80 & ." & 10 & 2 & 1 & 20 & 144.5 & & & \\
\hline 8.1. & $"$ & $2 \mathrm{D}$ & 2. & 1 & 20 & 144.5 & & . & \\
\hline 82 & $"$ & 30 & 2 & 1 & 20 & 144.5 & & & \\
\hline 83 & $"$ & 10 & 2 & 2 & 20 & 102.5 & & & \\
\hline 84 & $"$ & 20 & 2 & 2 & 20 & 102.5 & & & \\
\hline 85 & $"$ & 30 & 2 & 2 & 20 & 102.5 & & & \\
\hline 86 & $"$ & 1D & 2 & 3 & 20 & 147.6 & & & \\
\hline 87. & $"$ & 20 & 2 & 3 & 20 & 147.6 & & & \\
\hline 88 & $"$ & 30 & 2 & 3 & 20 & 147.6 & . & & \\
\hline 89 & E1 & 10 & 1 & 1 & 49 & 198.1 & & & \\
\hline 90 & $"$ & 20 & 1 & 1 & 49 & 194.1 & & & \\
\hline 91 & $"$ & $3 D$ & 1 & 1 & 49 & 184.4 & & & \\
\hline 92 & $"$ & 1D & 1 & 2 & 49 & 232.3 & 9.27 & 204.9 & 88.2 \\
\hline 93 & $"$ & $2 D$ & 1 & 2 & 49 & 232.3 & 9.27 & 203.0 & 87.3 \\
\hline
\end{tabular}


SUMPARY OF COULOMEIC EFF CIENCY TESTS

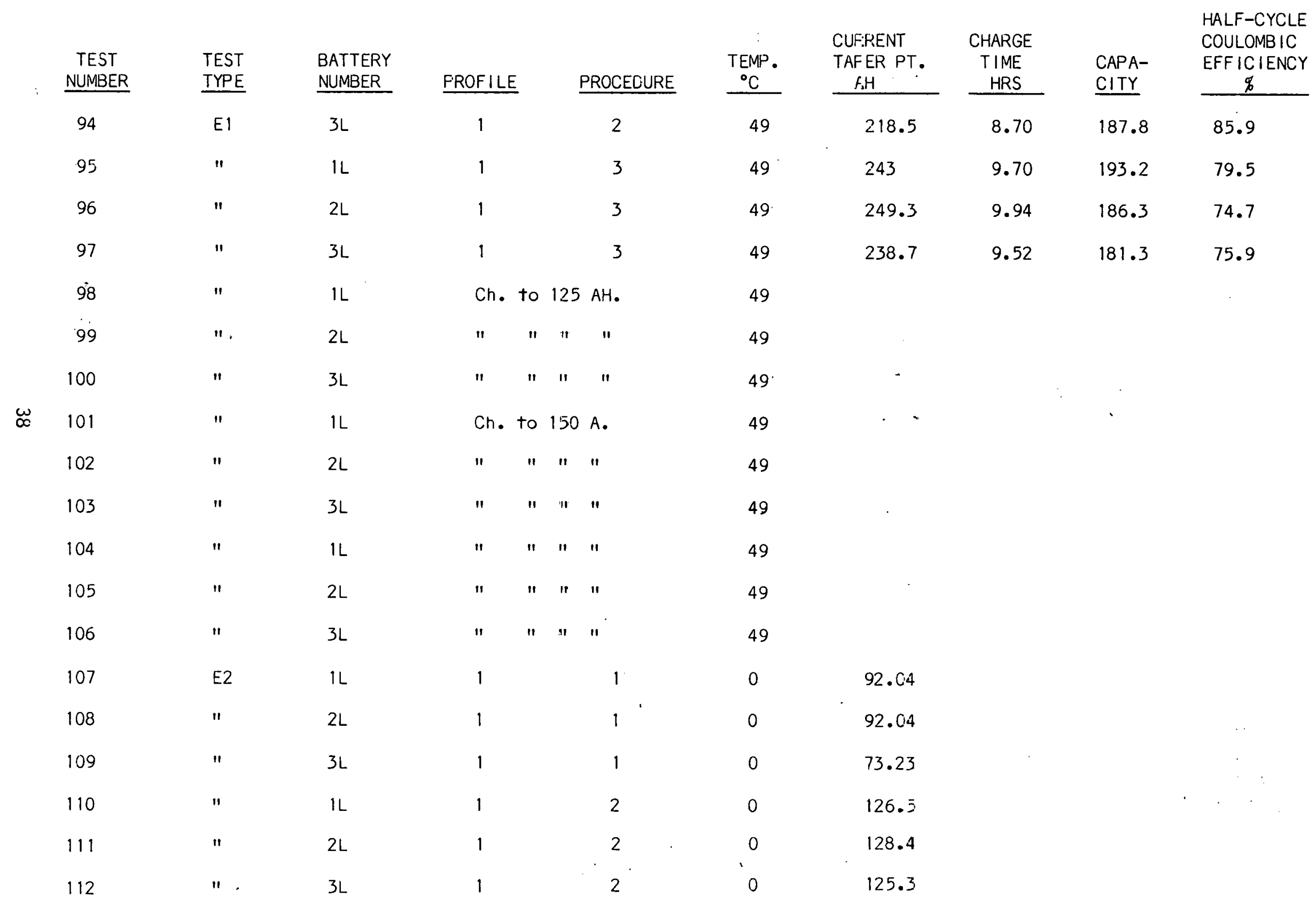


SUMMARY OF COULOMBIC EFFICIENCY TESTS

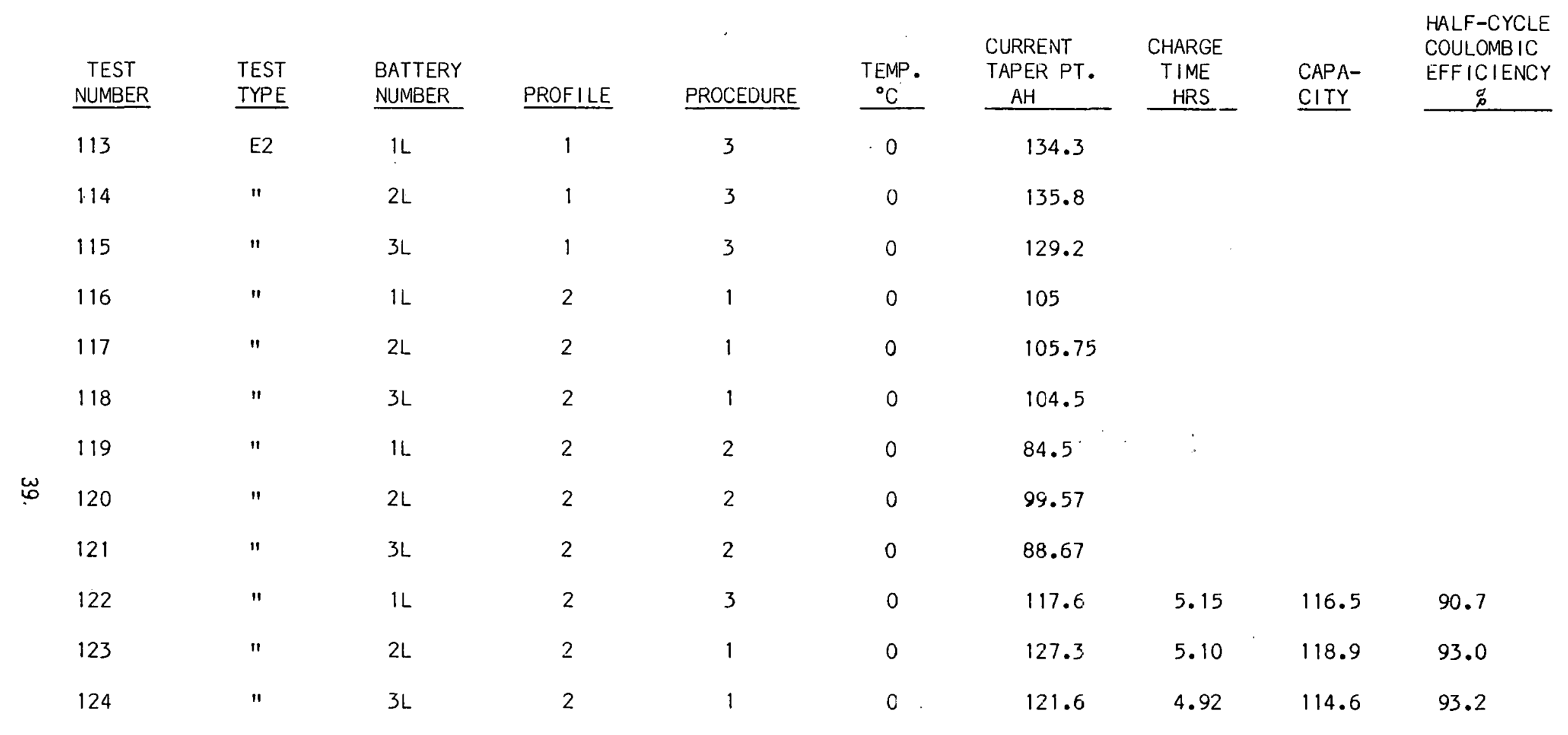


SUMMARY OF ENERGY EFFICIENCY TESTS

\begin{tabular}{|c|c|c|c|c|c|c|}
\hline $\begin{array}{c}\text { TEST } \\
\text { NUMBER } \\
\end{array}$ & $\begin{array}{l}\text { TEST } \\
\text { TYPE } \\
\end{array}$ & $\begin{array}{l}\text { BATTERY } \\
\text { NUUMBER } \\
\end{array}$ & PROFILE & PROCEDURE & $\begin{array}{l}\text { TEMP. } \\
{ }^{\circ} \mathrm{C} \\
\end{array}$ & $\begin{array}{l}\text { CURRENT } \\
\text { TAPER PT. } \\
\text { AH } \\
\end{array}$ \\
\hline 125 & A & $2 L$ & 1 & 1 & 20 & 153 \\
\hline 126 & $"$ & $1 \mathrm{~L}$ & 1 & 2 & 20 & 162.5 \\
\hline 127 & $"$ & $3 L$ & 1 & 3 & 20 & 184.25 \\
\hline 128 & !" & $1 \mathrm{~L}$ & 2 & 1 & 20 & 170 \\
\hline 129 & $"$ & $1 \mathrm{~L}, 2 \mathrm{~L}, 3 \mathrm{~L}$ & 2 & 2 & 20 & $179.89,181.45,177.27$ \\
\hline 130 & $"$ & $3 L$ & 2 & 3 & 20 & 195.8 \\
\hline 131 & $"$ & $1 L, 2 L, 3 L$ & 3 & 1 & 20 & $183,189.25,176.5$ \\
\hline 132 & $"$ & $1 L, 2 L, 3 L$ & 3 & 2 & 20 & $185,189.25,169.5$ \\
\hline 133 & $"$ & $1 L, 2 L, 3 L$ & 3 & 3 & 20 & $161.75,167,151.25$ \\
\hline 134 & B & $1 L, 2 L, 3 L$ & 1 & 1 & 20 & $153.75,157,145.75$ \\
\hline 135 & $"$ & $1 L, 2 L, 3 L$ & 1 & 3 & 20 & $195.4,199.8,198.3$ \\
\hline 136 & $"$ & $1 L, 2 L, 3 L$ & 2 & 1 & 20 & $172.75,178,168.25$ \\
\hline 137 & $"$ & $1 L, 2 L, 3 L$ & 2 & 3 & 20 & $198.5,195.2,188.3$ \\
\hline 138 & $"$ & $2 L$ & 3 & 1 & 20 & 160 \\
\hline 139 & $"$ & $3 L$ & 3 & 3 & 20 & - \\
\hline 140 & E1 & $1 L, 2 L, 3 L$ & 1 & 1 & 49 & $198.1,194,184.4$ \\
\hline 141 & $"$ & $1 L, 2 L, 3 L$ & 1 & 2 & 49 & $232.3,232.5,218.5$ \\
\hline 142 & $"$ & $1 L, 2 L, 3 L$ & 1 & 3 & 49 & $248,249.3,238.7$ \\
\hline *143 & $"$ & $1 L, 2 L, 3 L$ & & · & 49 & . \\
\hline
\end{tabular}


SUMMARY OF ENERGY EPG TESTS

\begin{tabular}{|c|c|c|c|c|c|c|}
\hline $\begin{array}{c}\text { TEST } \\
\text { NUMBER }\end{array}$ & $\begin{array}{l}\text { TEST } \\
\text { IYPE }\end{array}$ & $\begin{array}{l}\text { BATTERY } \\
\text { NUMBER } \\
\end{array}$ & PROFILE & PROCEDURE & $\begin{array}{l}\text { TEMP. } \\
\text { 足 } \\
\end{array}$ & $\begin{array}{l}\text { CURRENT } \\
\text { TAPER PT. } \\
\text { AH } \\
\end{array}$ \\
\hline$*_{144}$ & E1 & $1 L, 2 L, 3 L$ & & & 49 & \\
\hline *145 & $"$ & $1 L, 2 L, 3 L$ & & & 49 & \\
\hline 146 & E2 & $1 L, 2 L, 3 L$ & 1 & 1 & 0 & $92.04,92.04,73.23$ \\
\hline 147 & $"$ & $1 L, 2 L, 3 L$ & 1 & 2 & 0 & \\
\hline 148 & $"$ & $1 L, 2 L, 3 L$ & 1 & 3 & 0 & \\
\hline 149 & $"$ & $1 L, 2 L, 3 L$ & 2 & 1 & 0 & \\
\hline 150 & $"$ & $1 L, 2 L, 3 L$ & 2 & 2 & 0 & \\
\hline 151 & " & $1 \mathrm{~L}, 2 \mathrm{~L}, 3 \mathrm{~L}$ & 2 & 3 & 0 & \\
\hline
\end{tabular}




\section{THIS PAGE \\ WAS INTENTIONALLY \\ LEFT BLANK}


APPENDIX A

COULOMBIC EFFICIENCY TESTS OF ESB EV-106 LEAD-ACID BATTERIES 


\section{THIS PAGE \\ WAS INTENTIONALLY \\ LEFT BLANK}



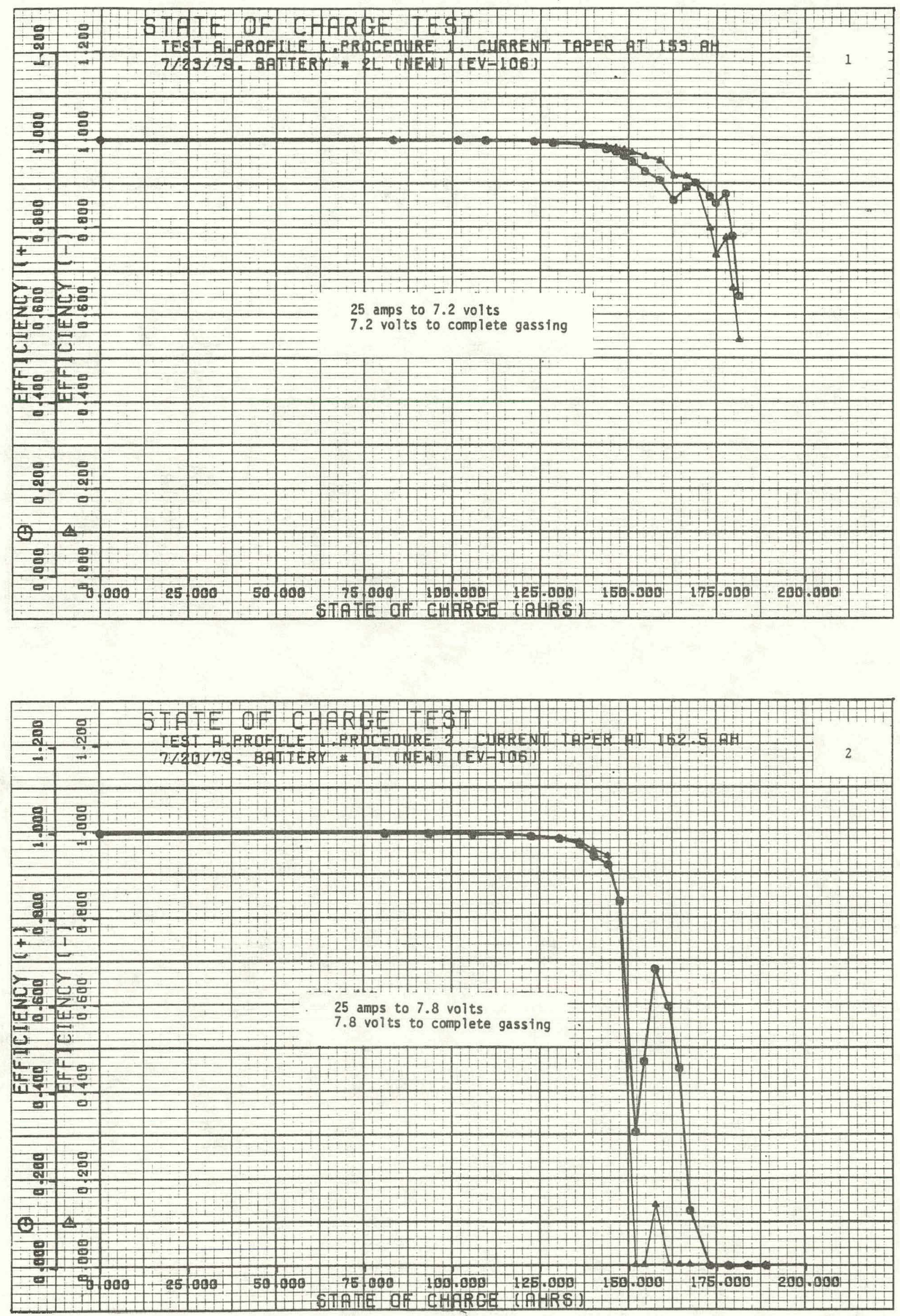

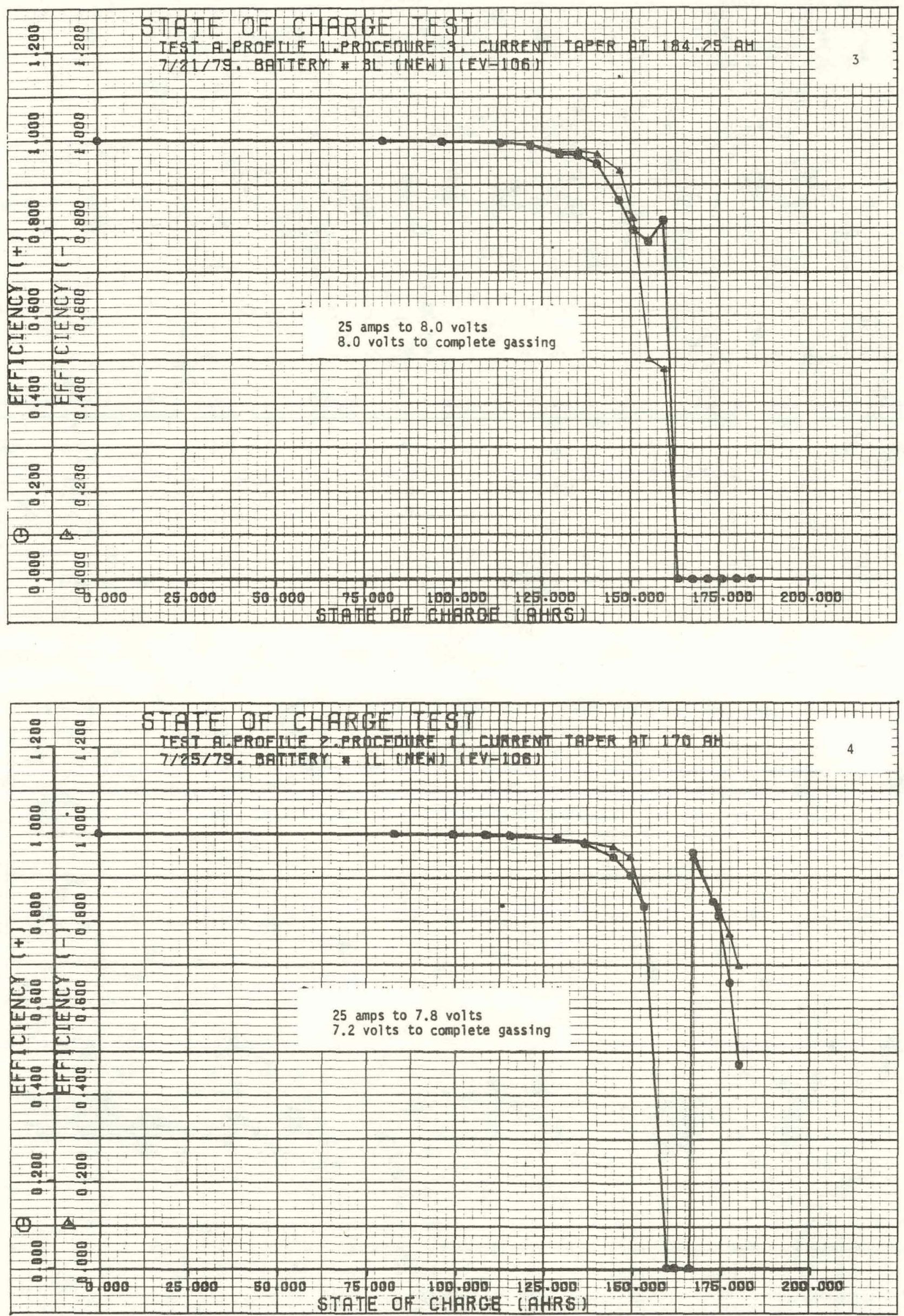

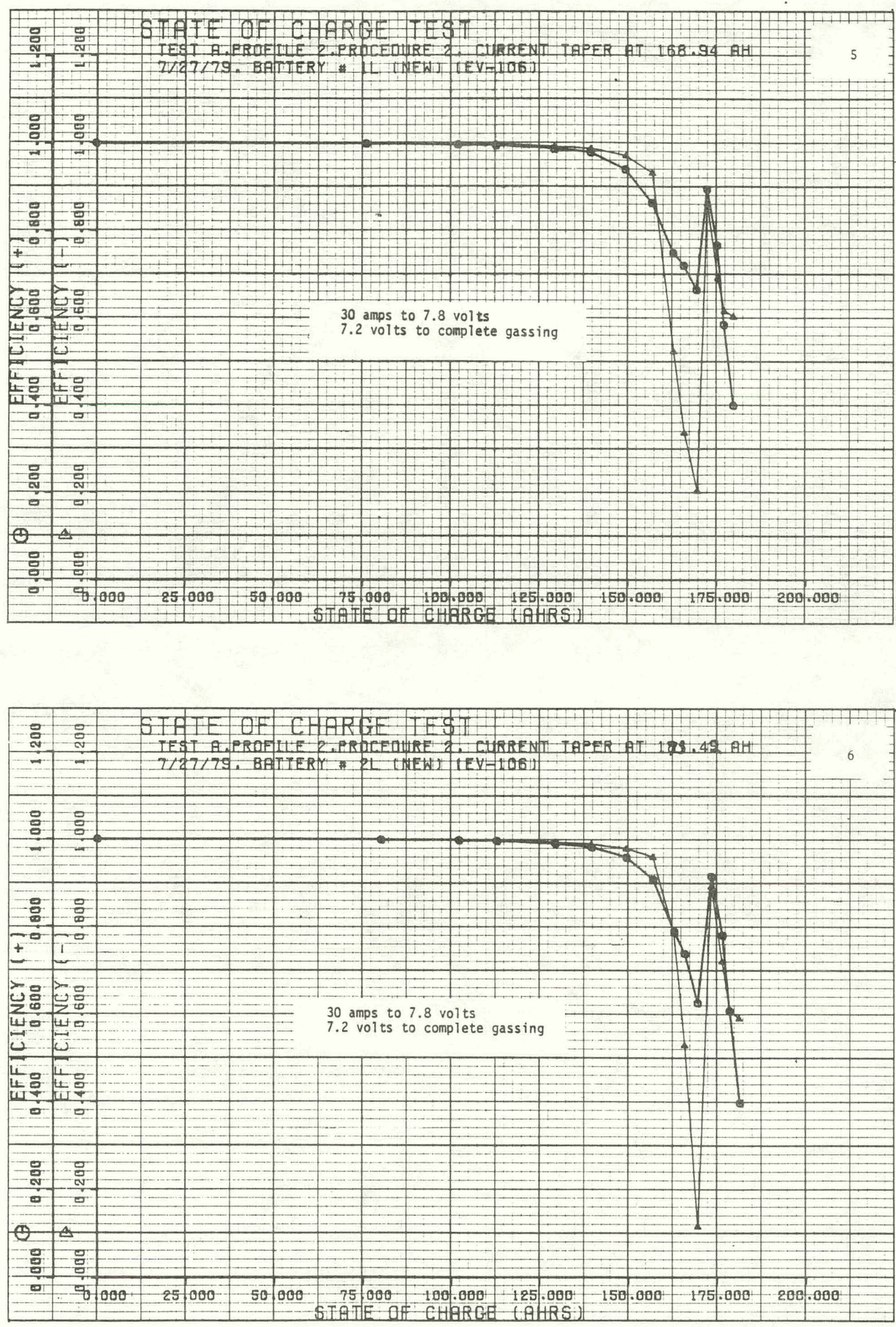

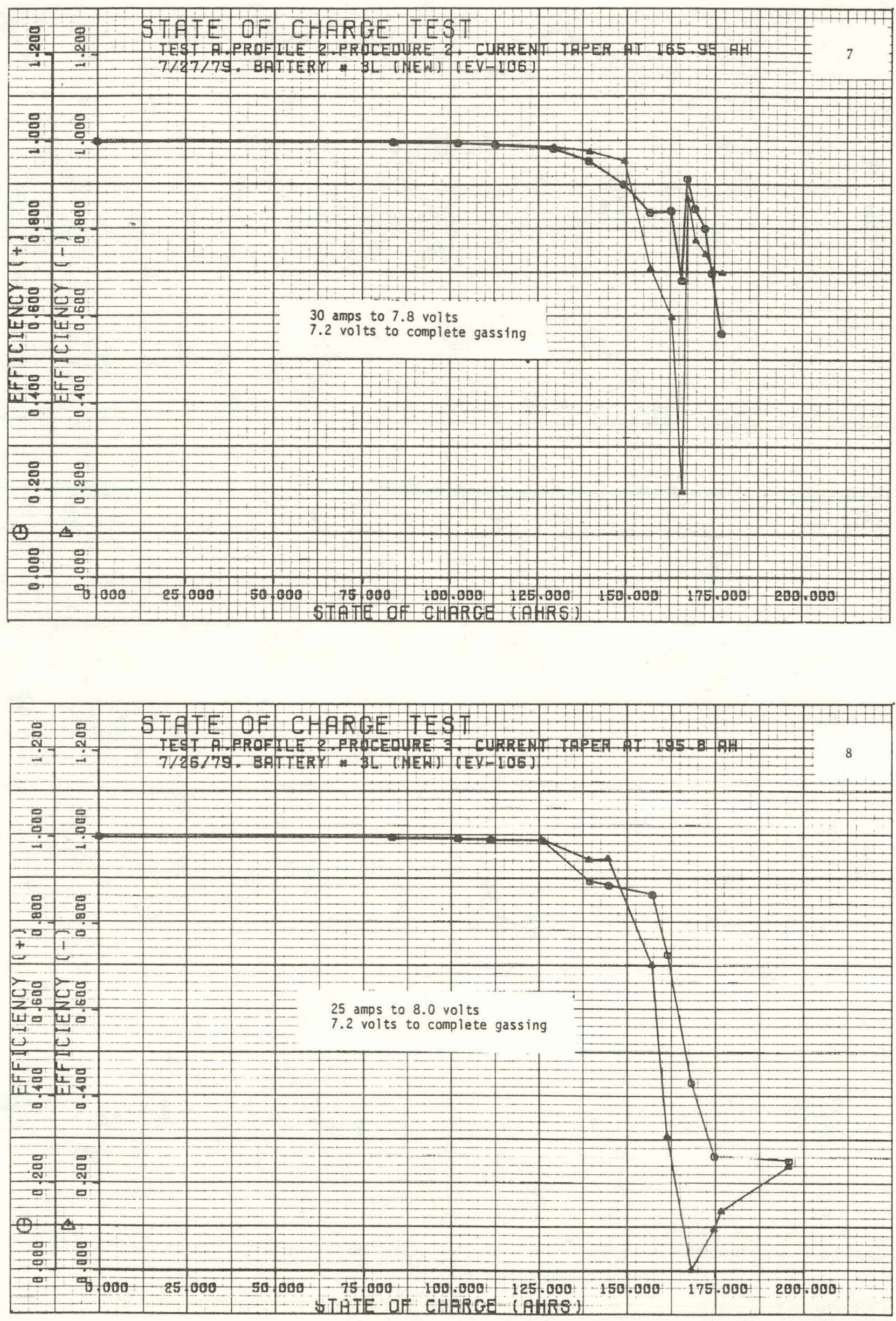

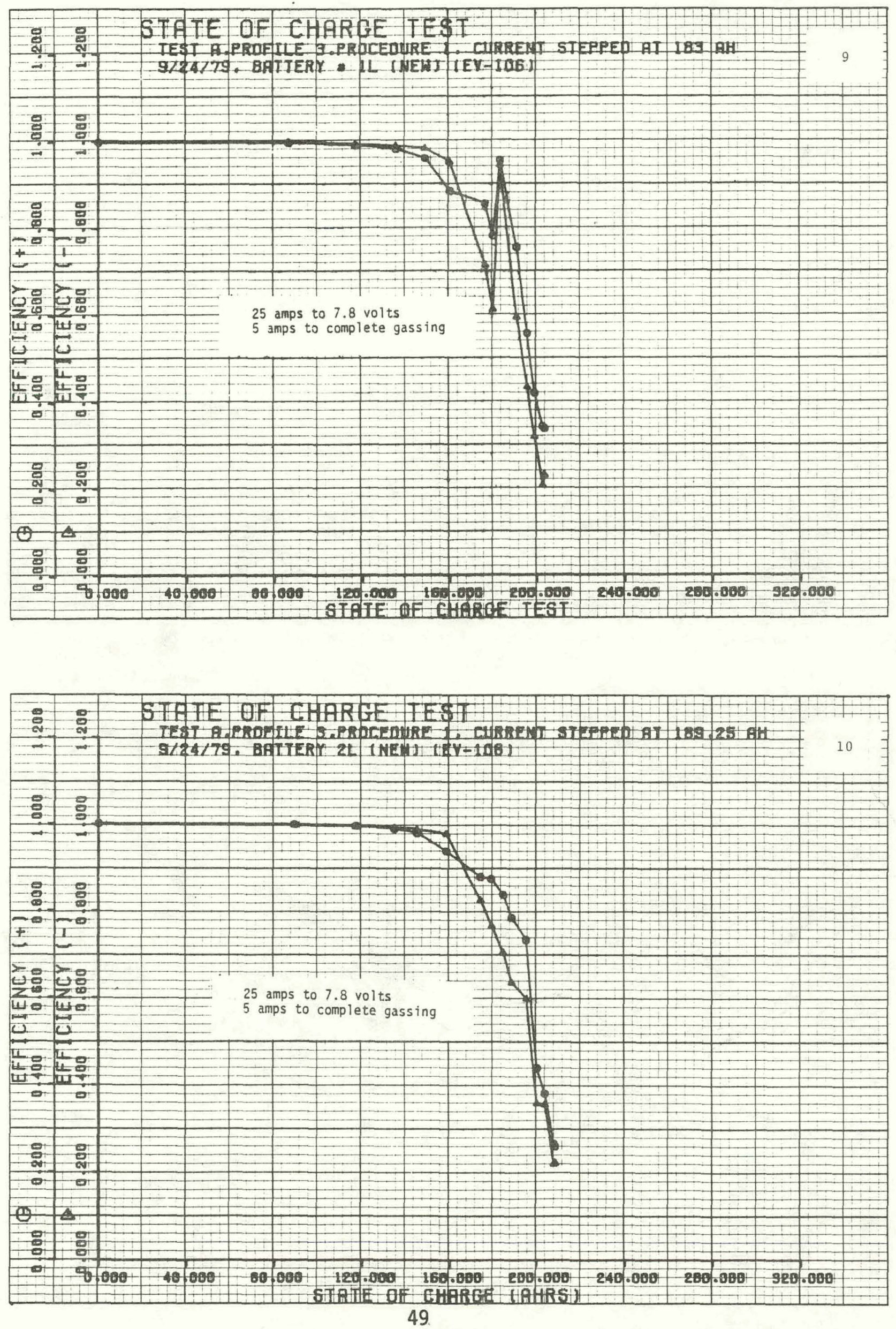

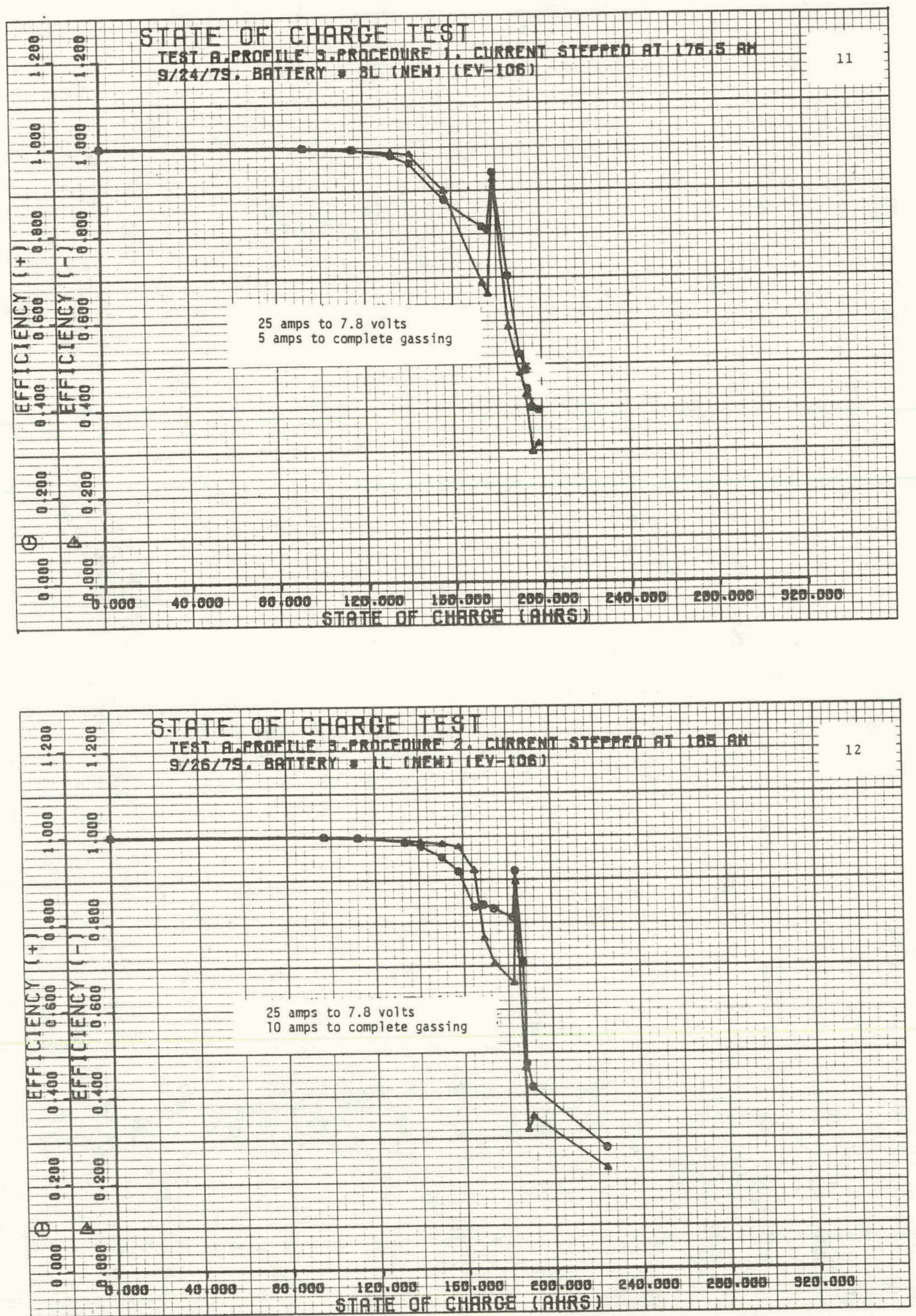

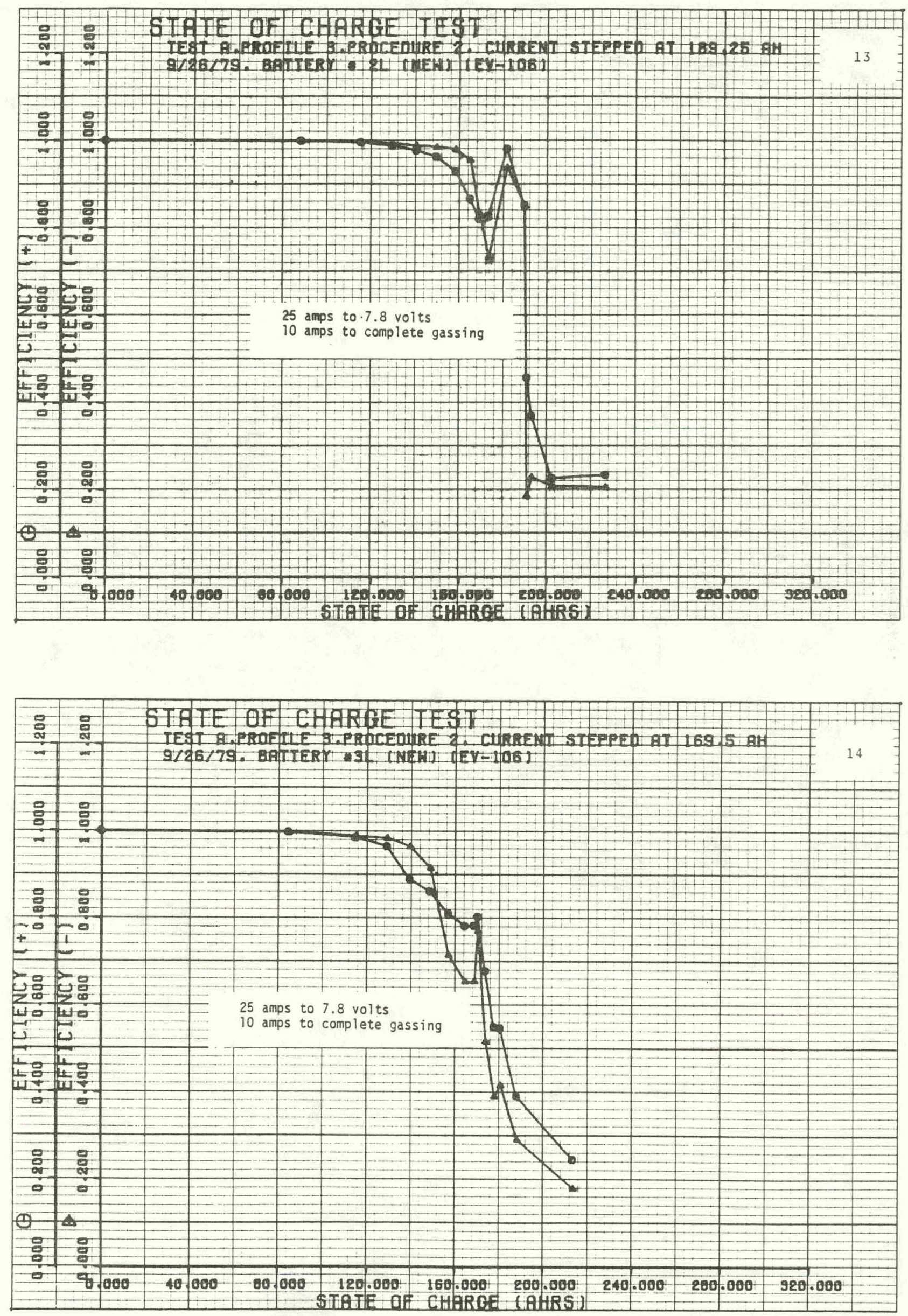

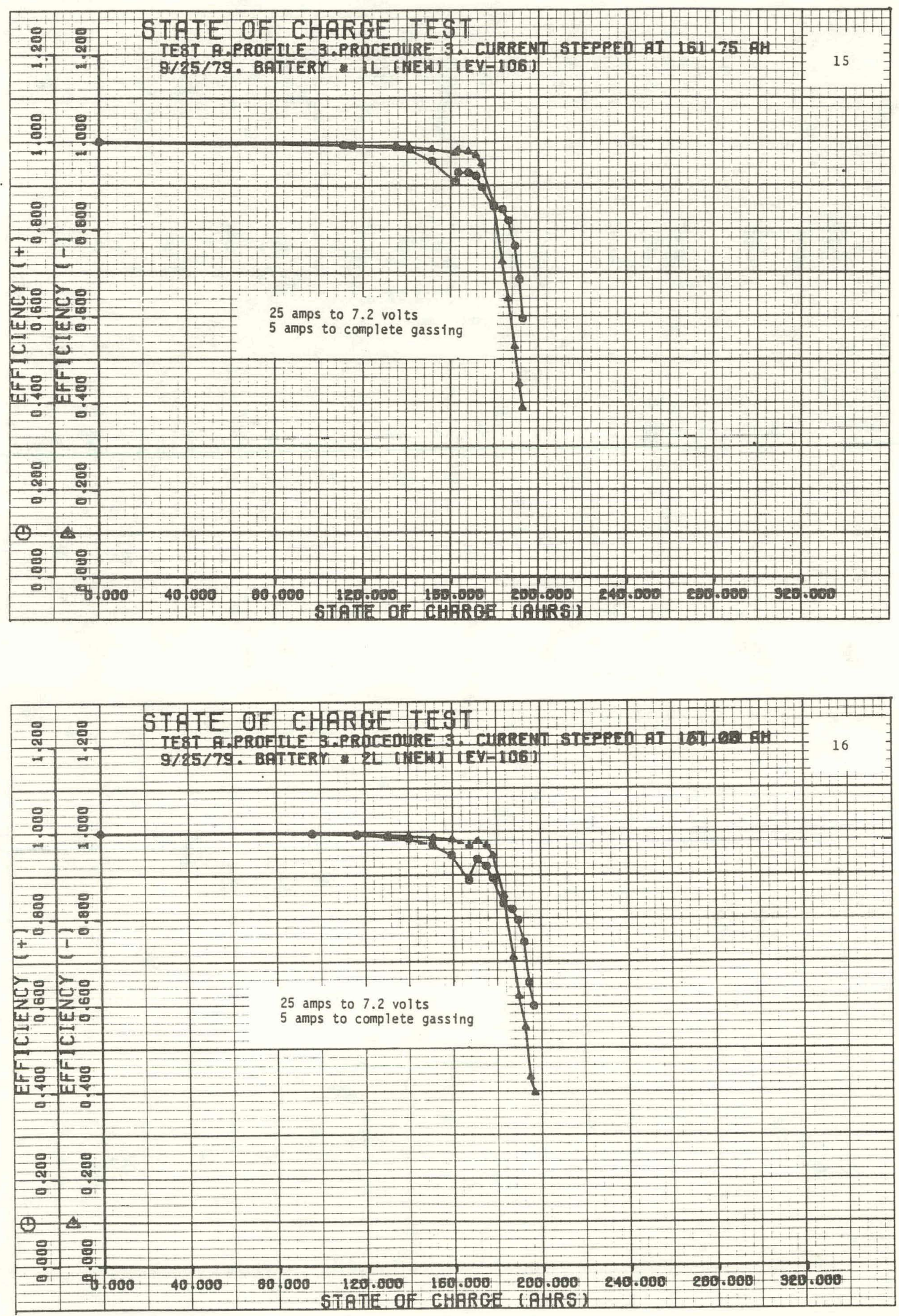

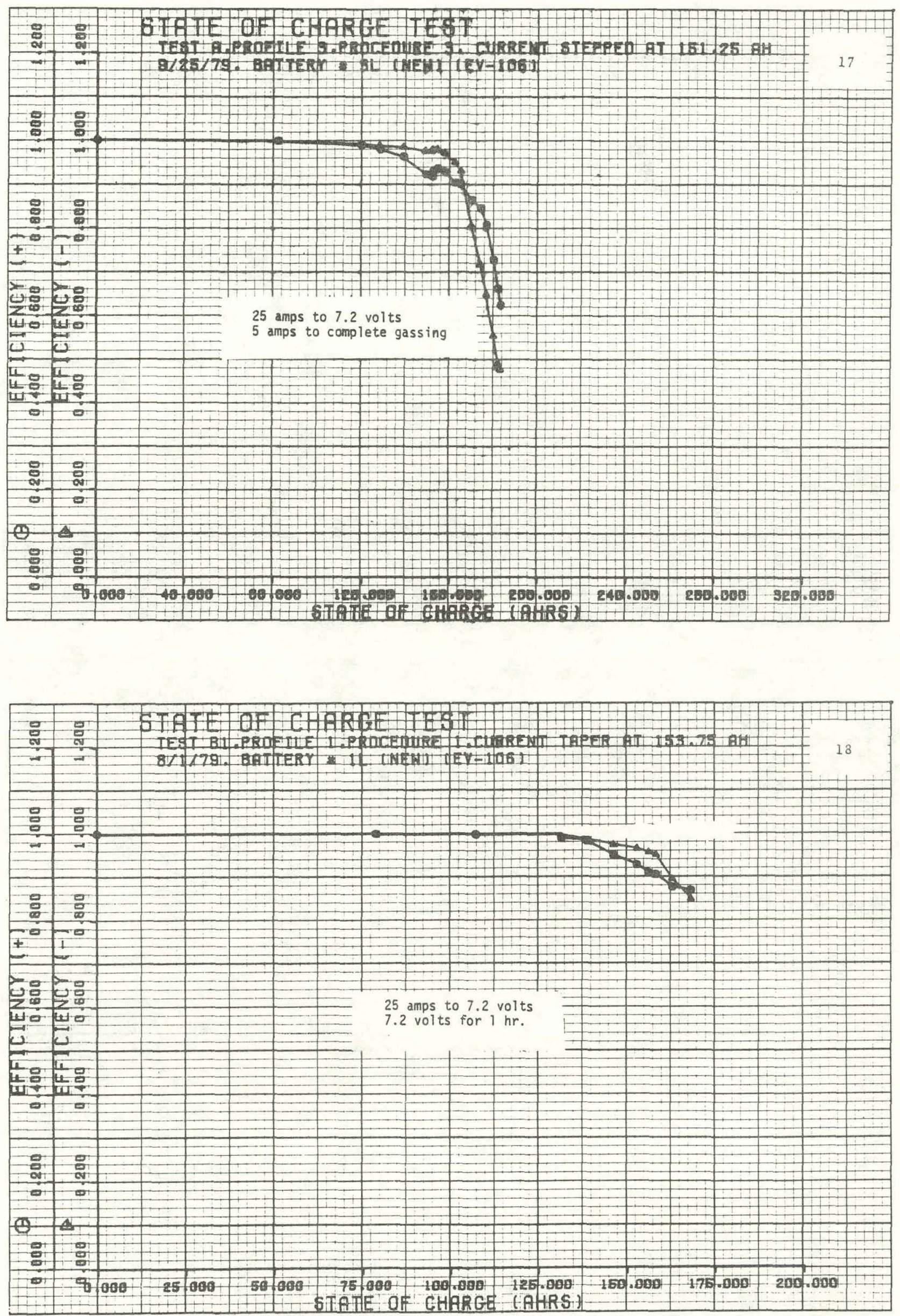

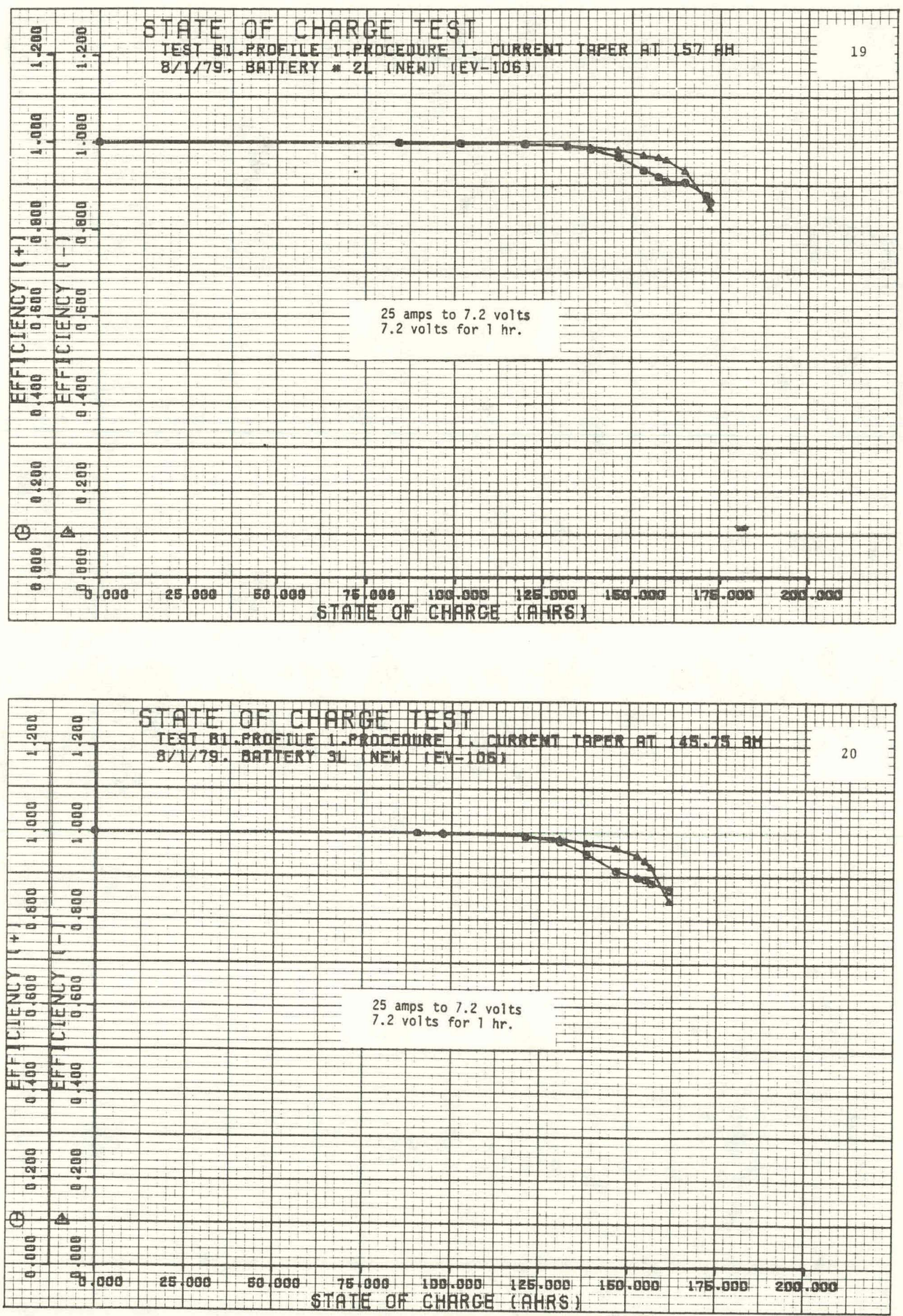

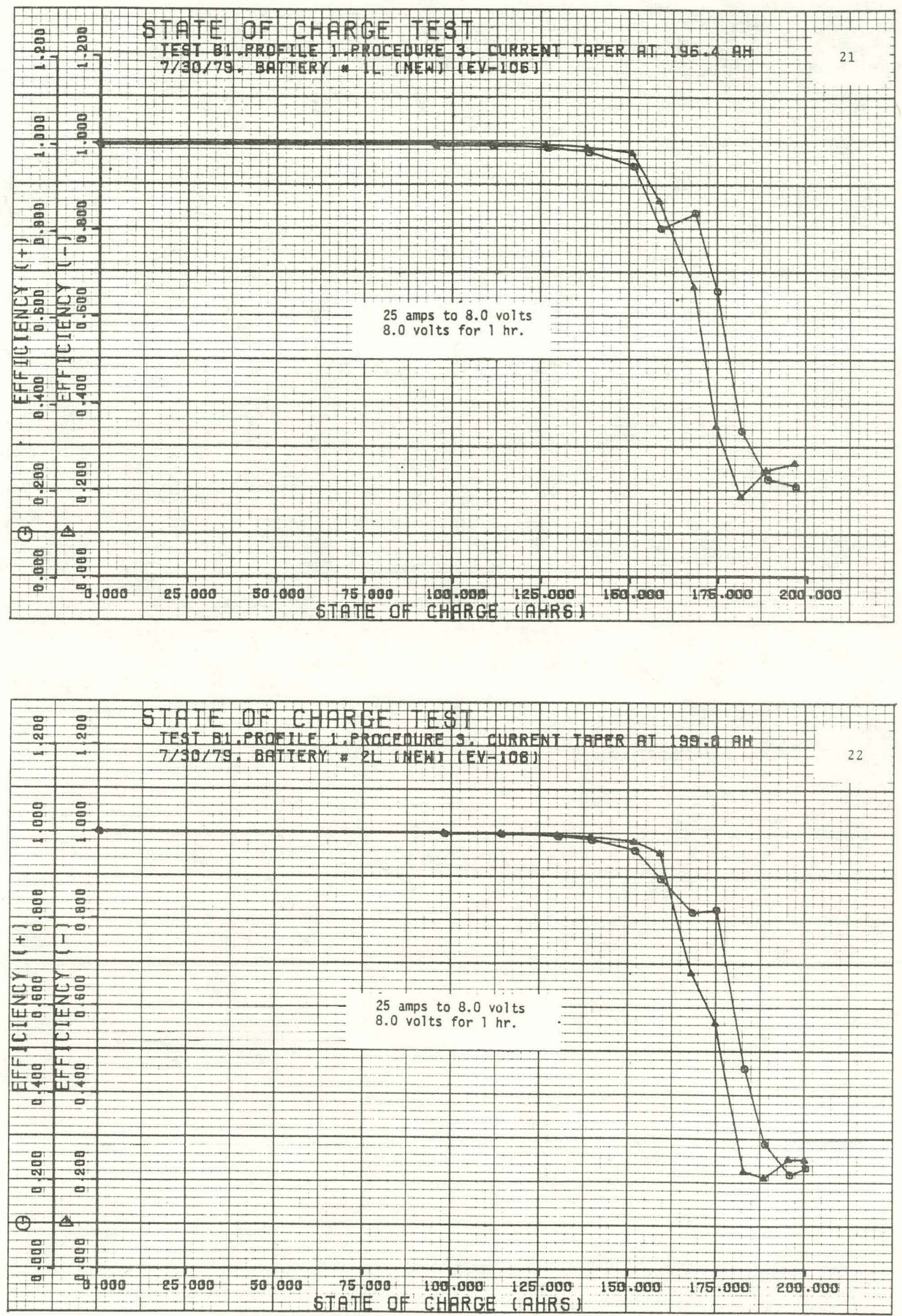

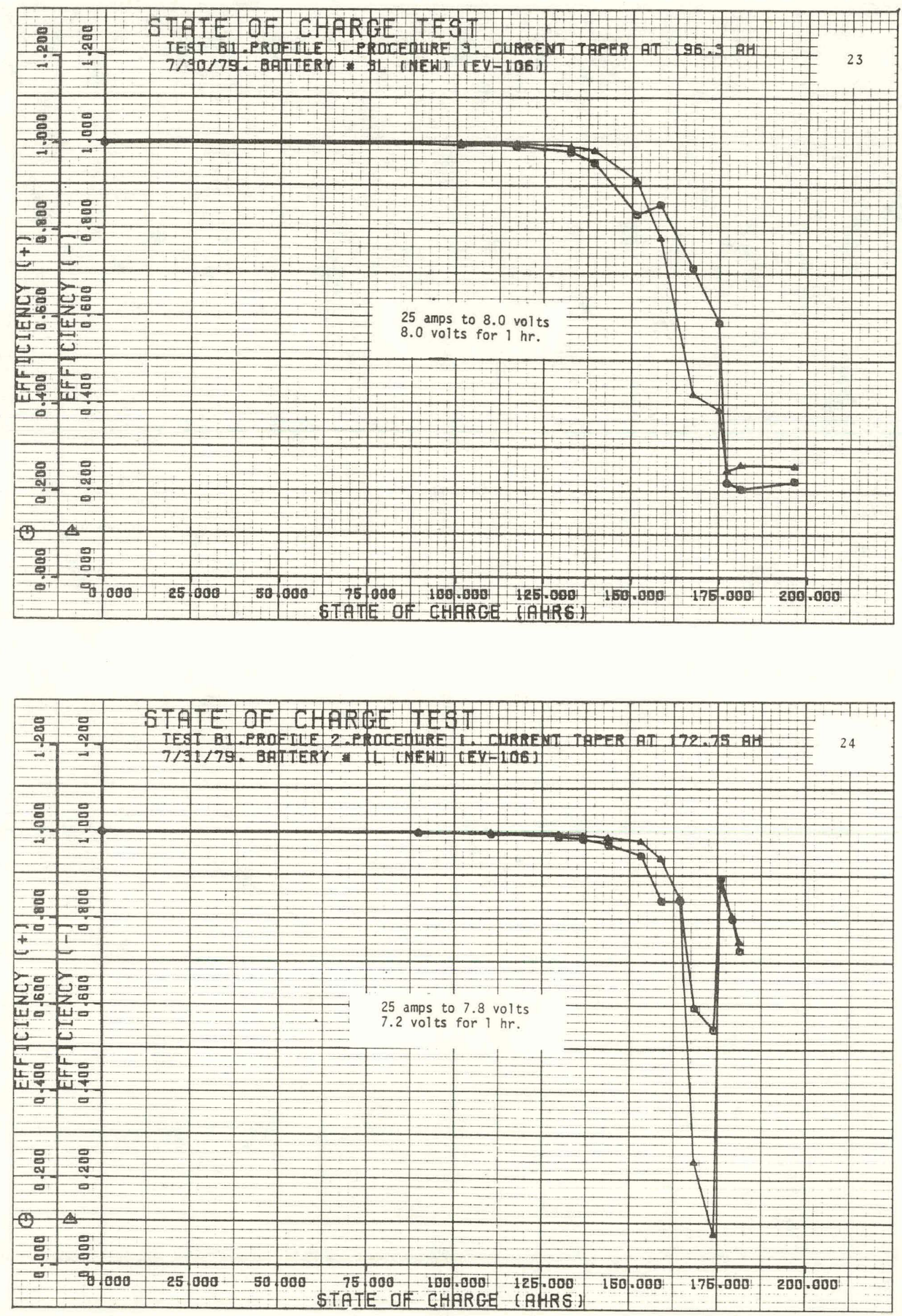

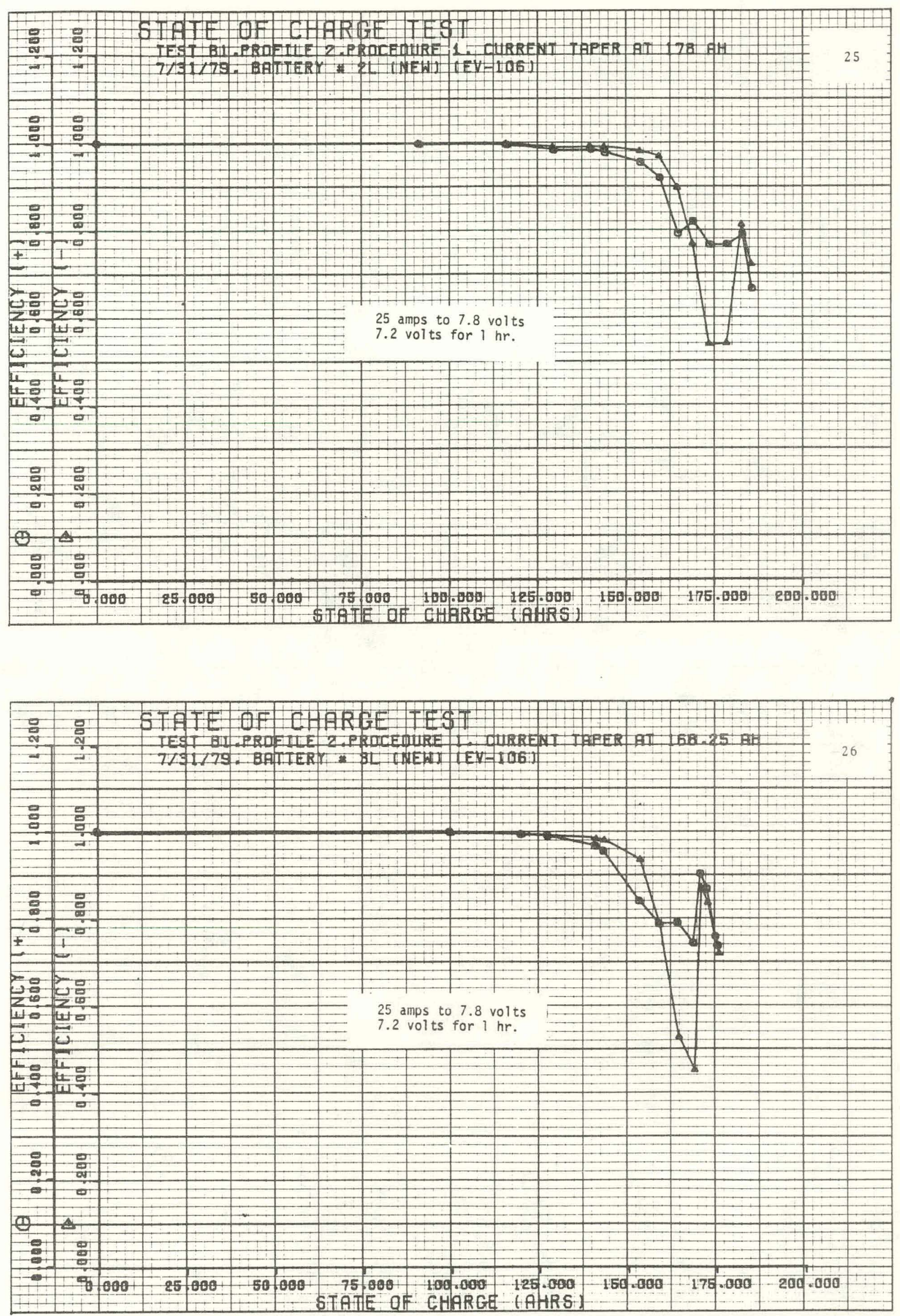

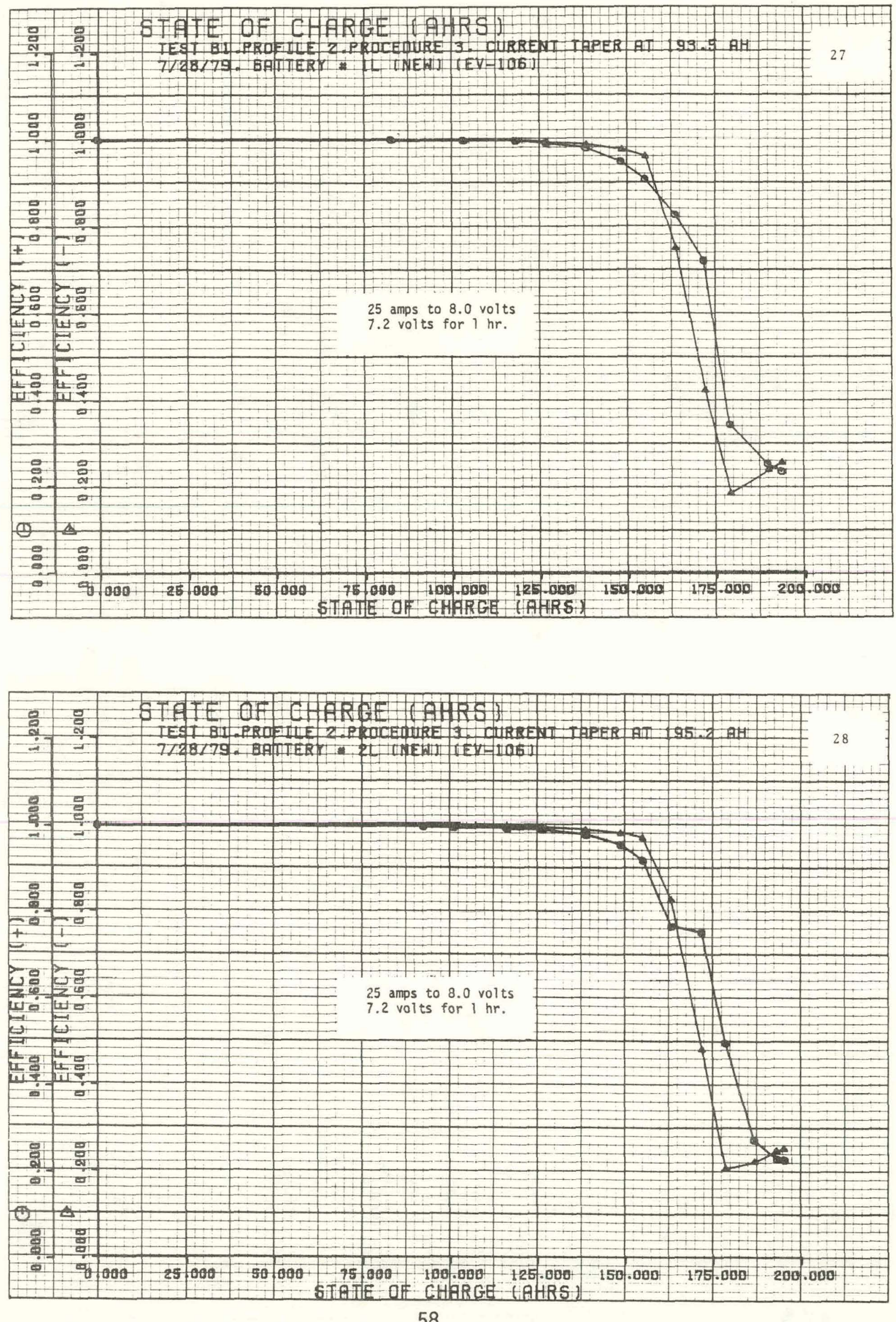

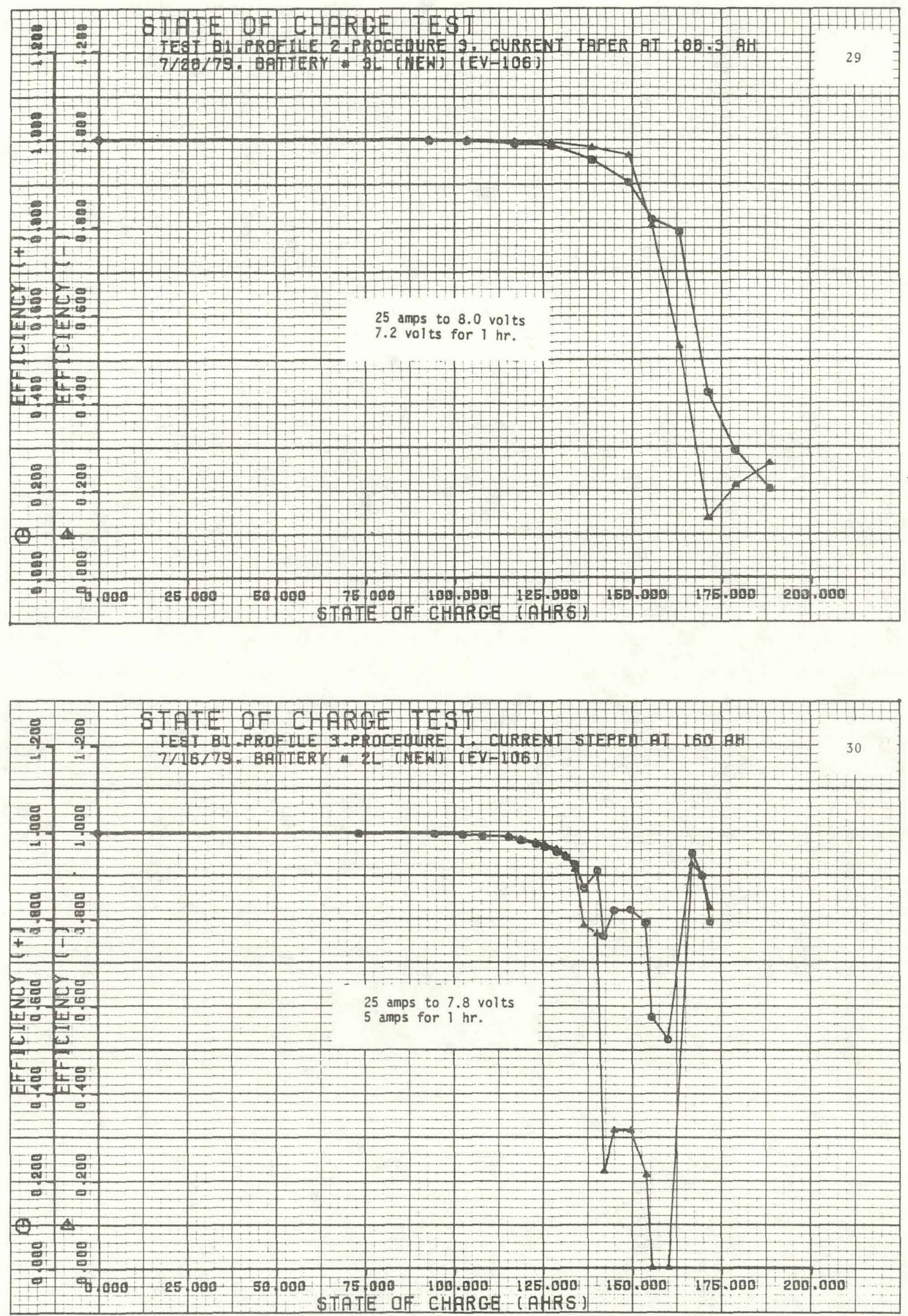

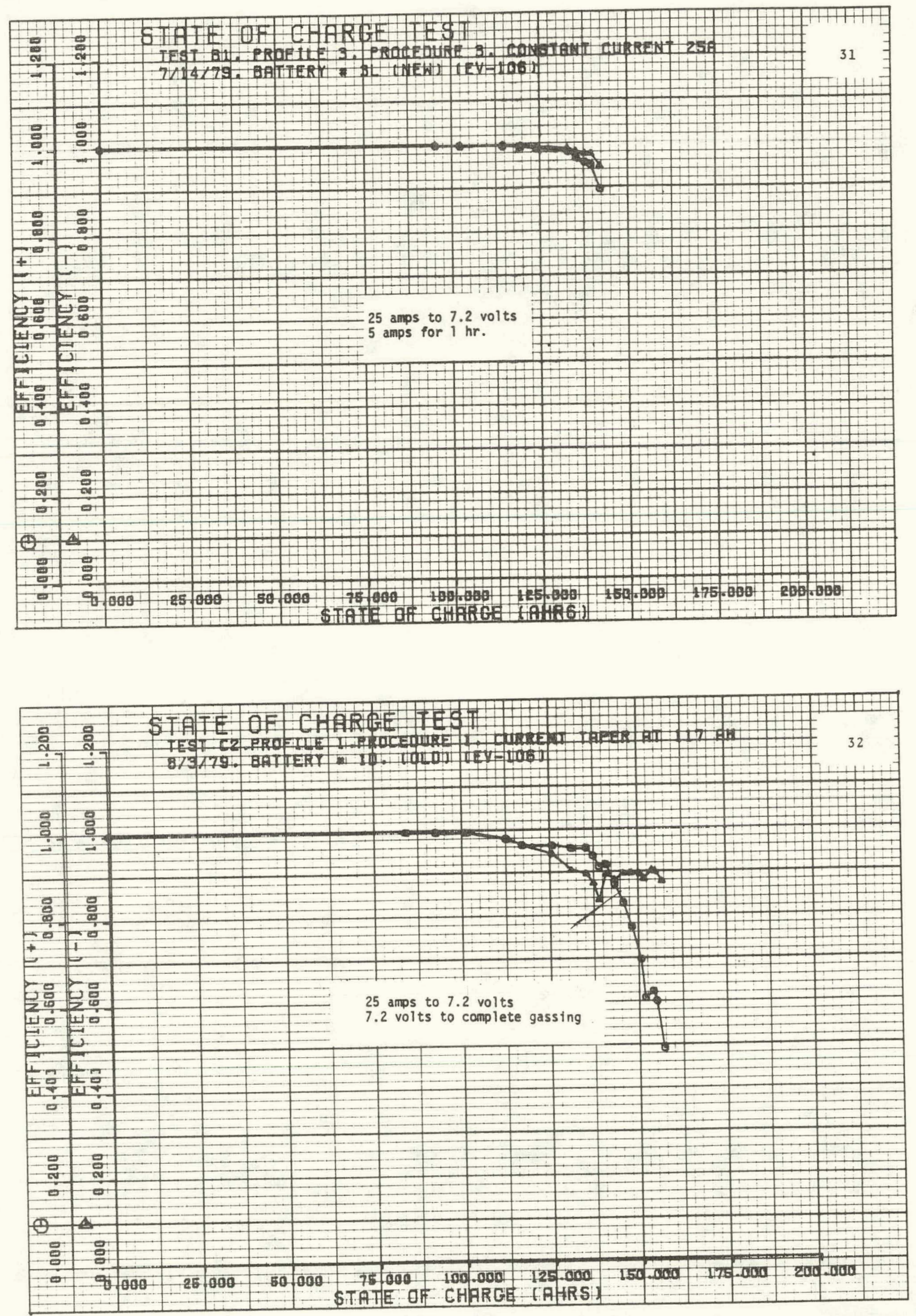

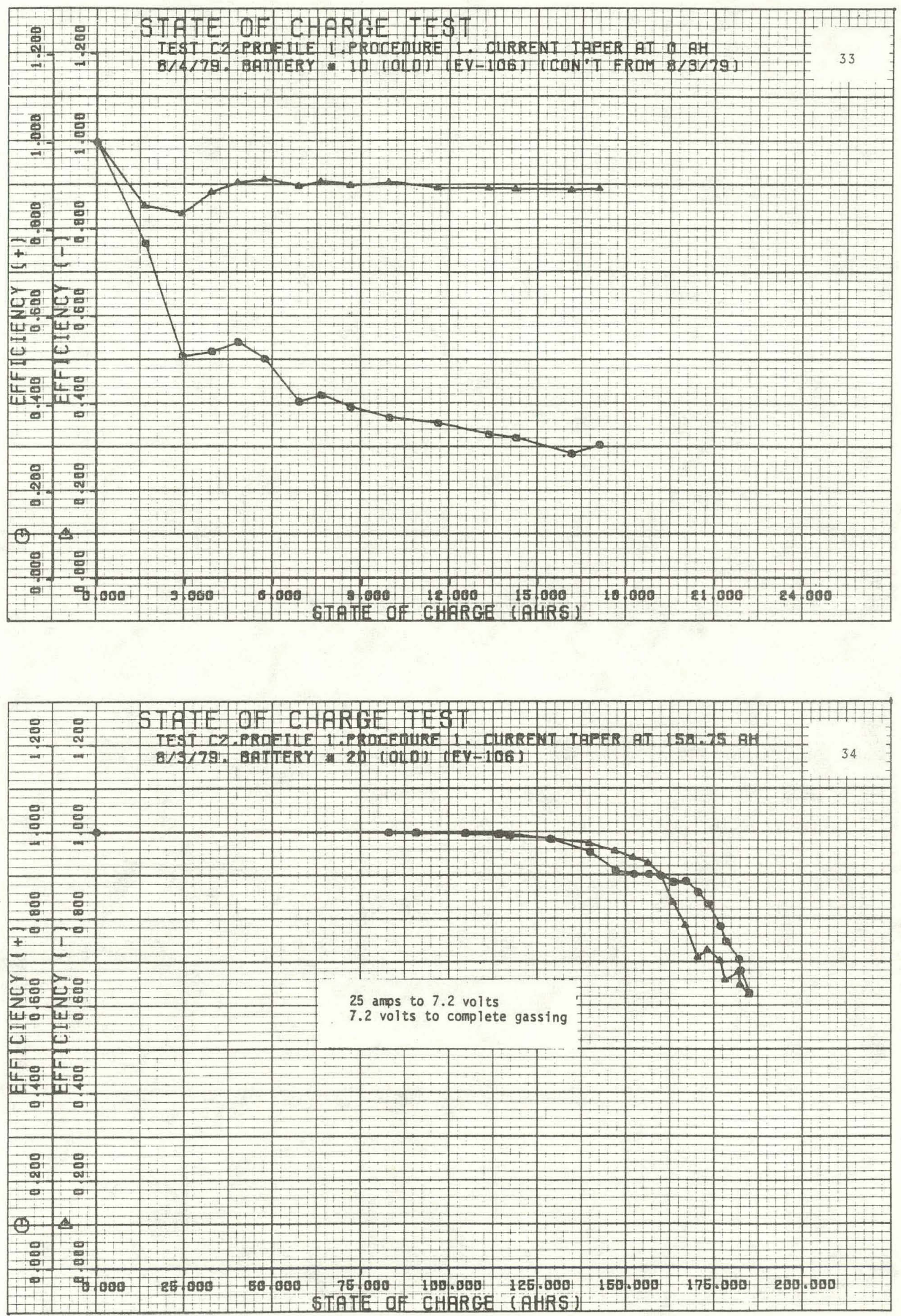

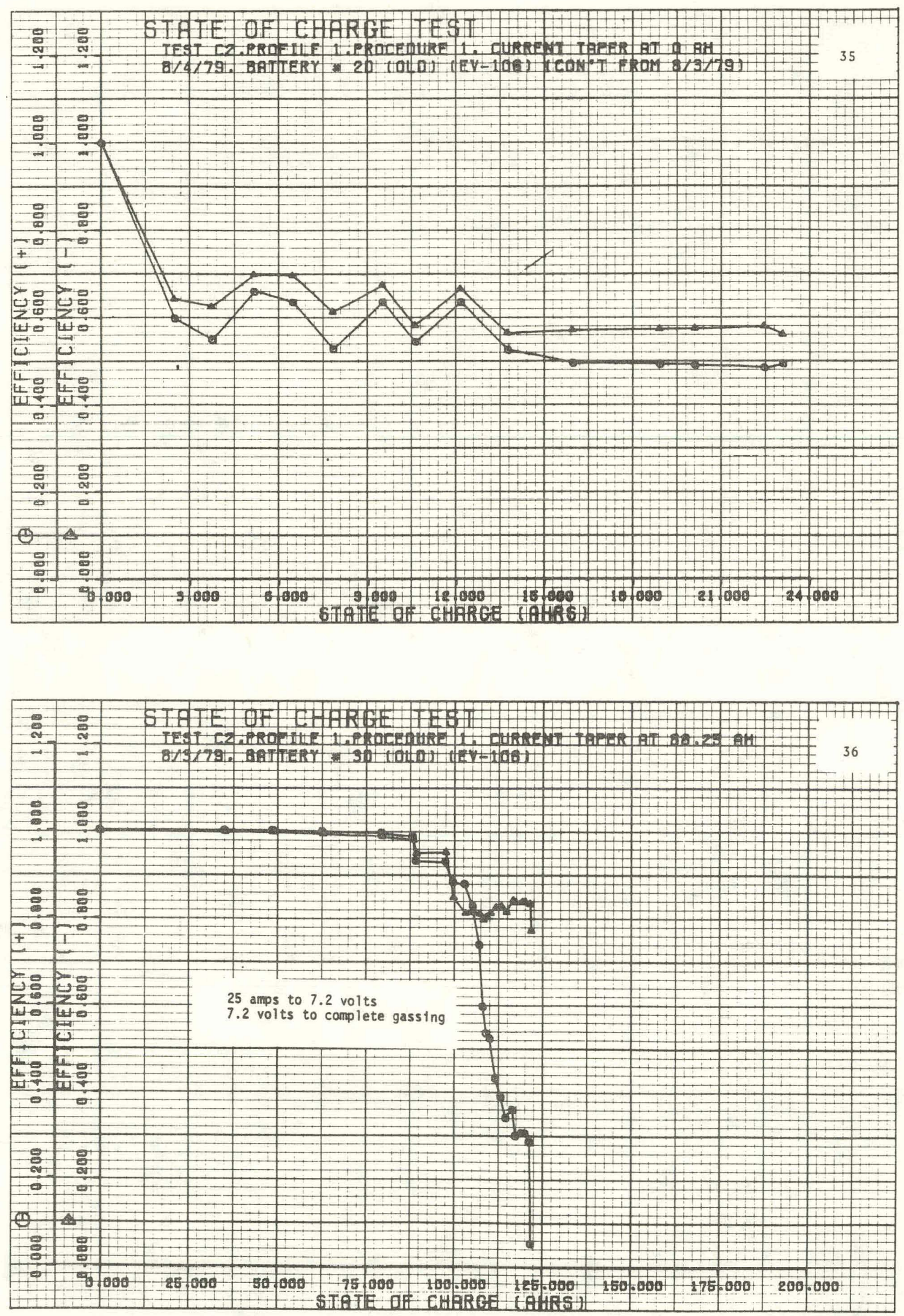

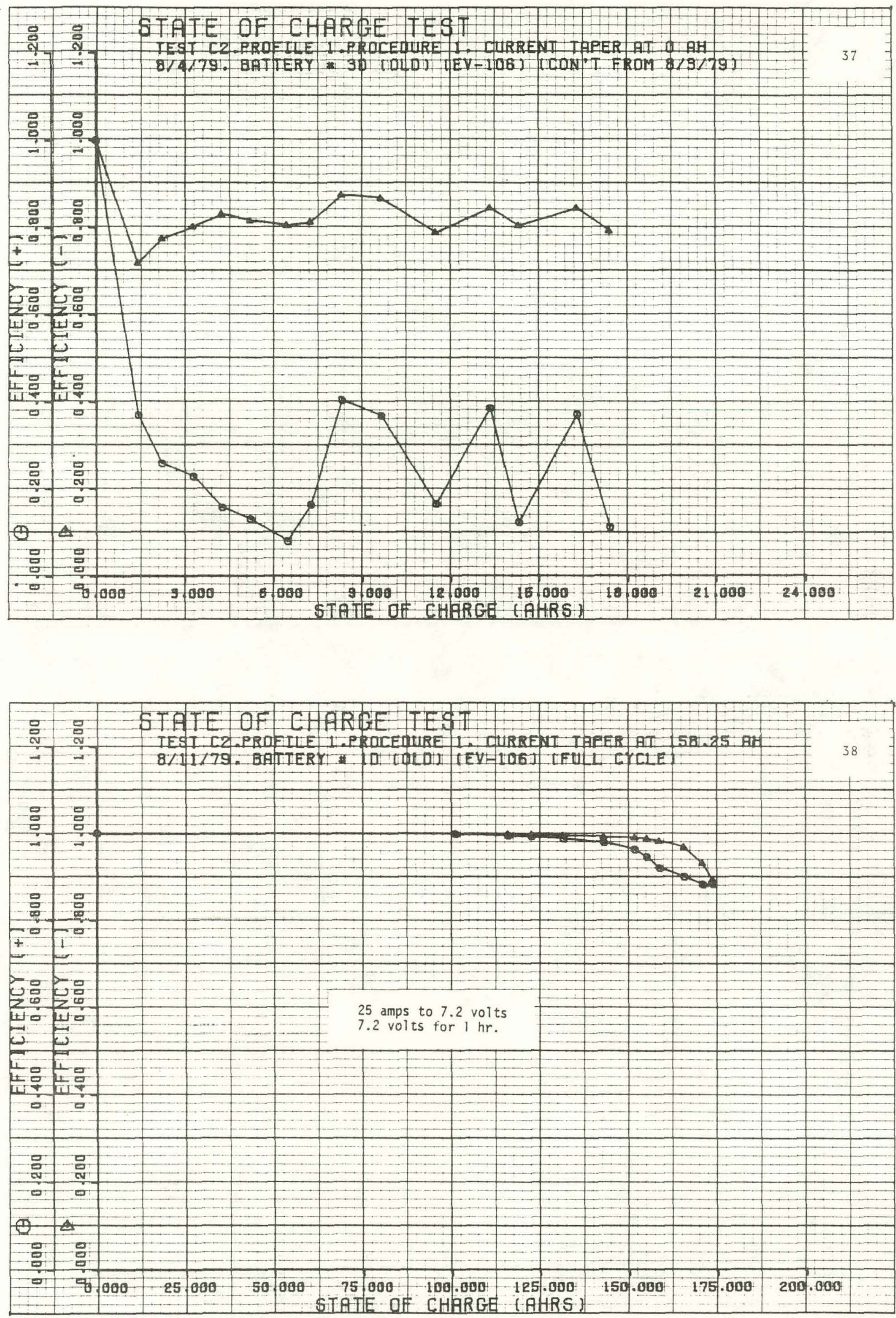

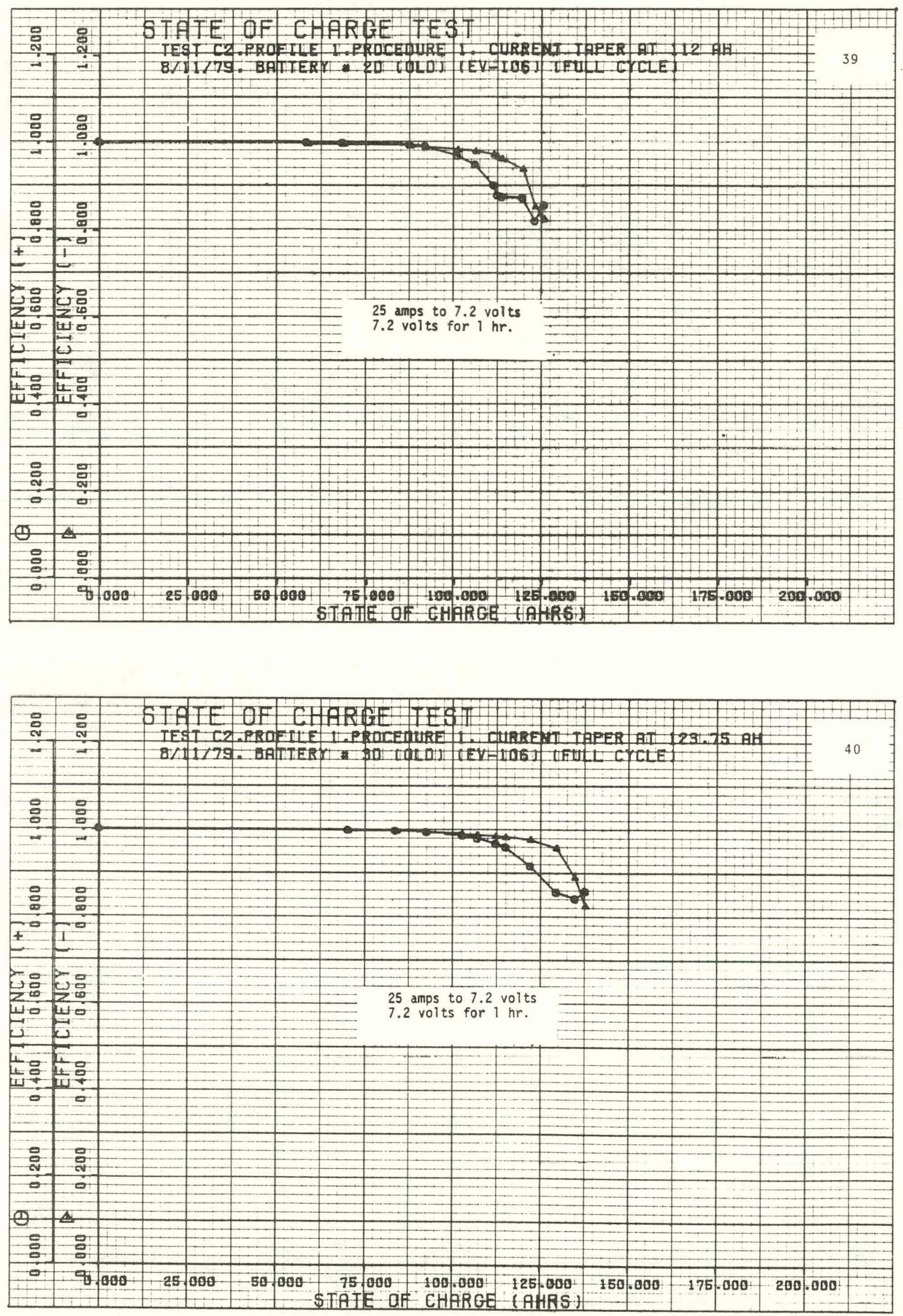

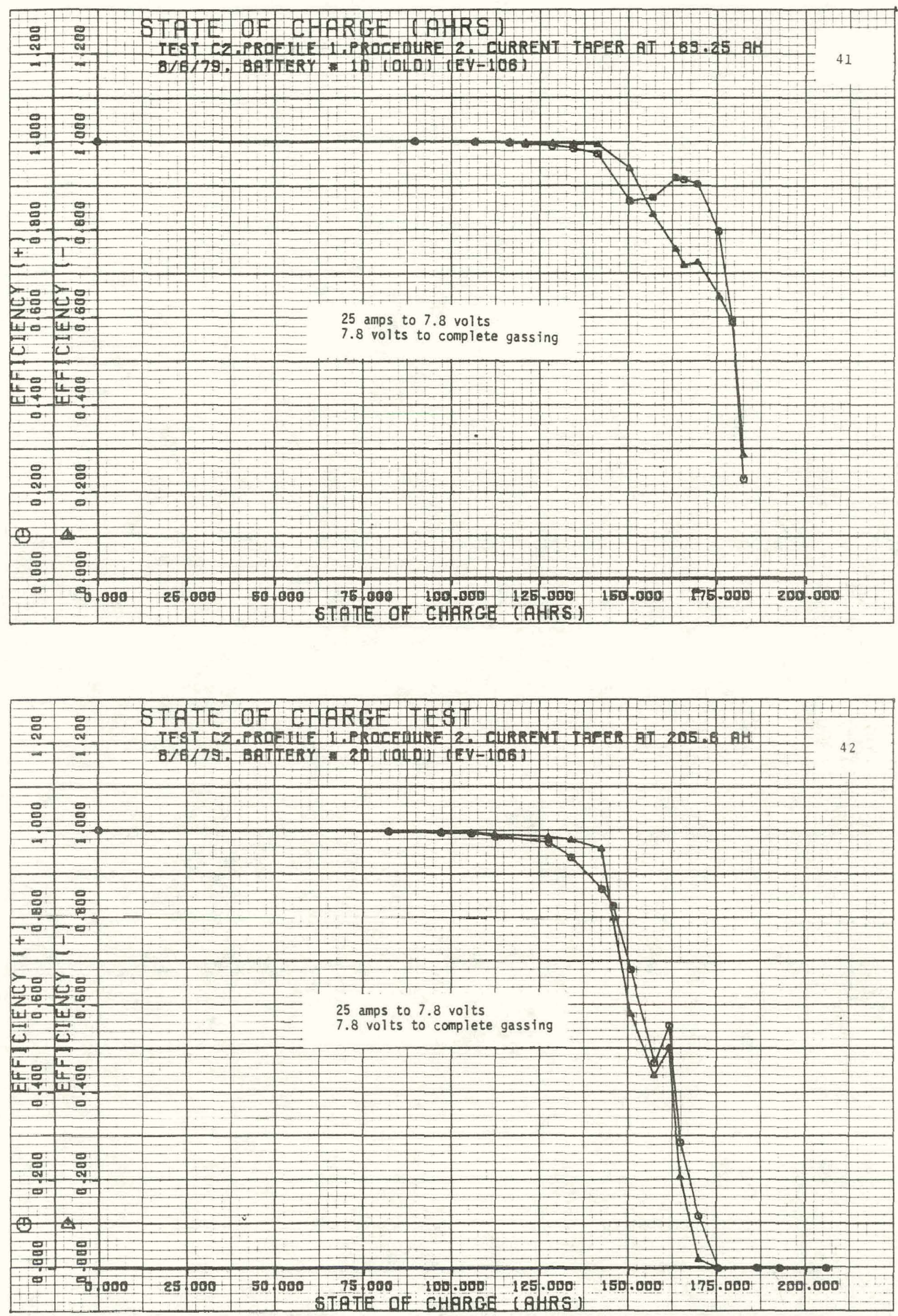

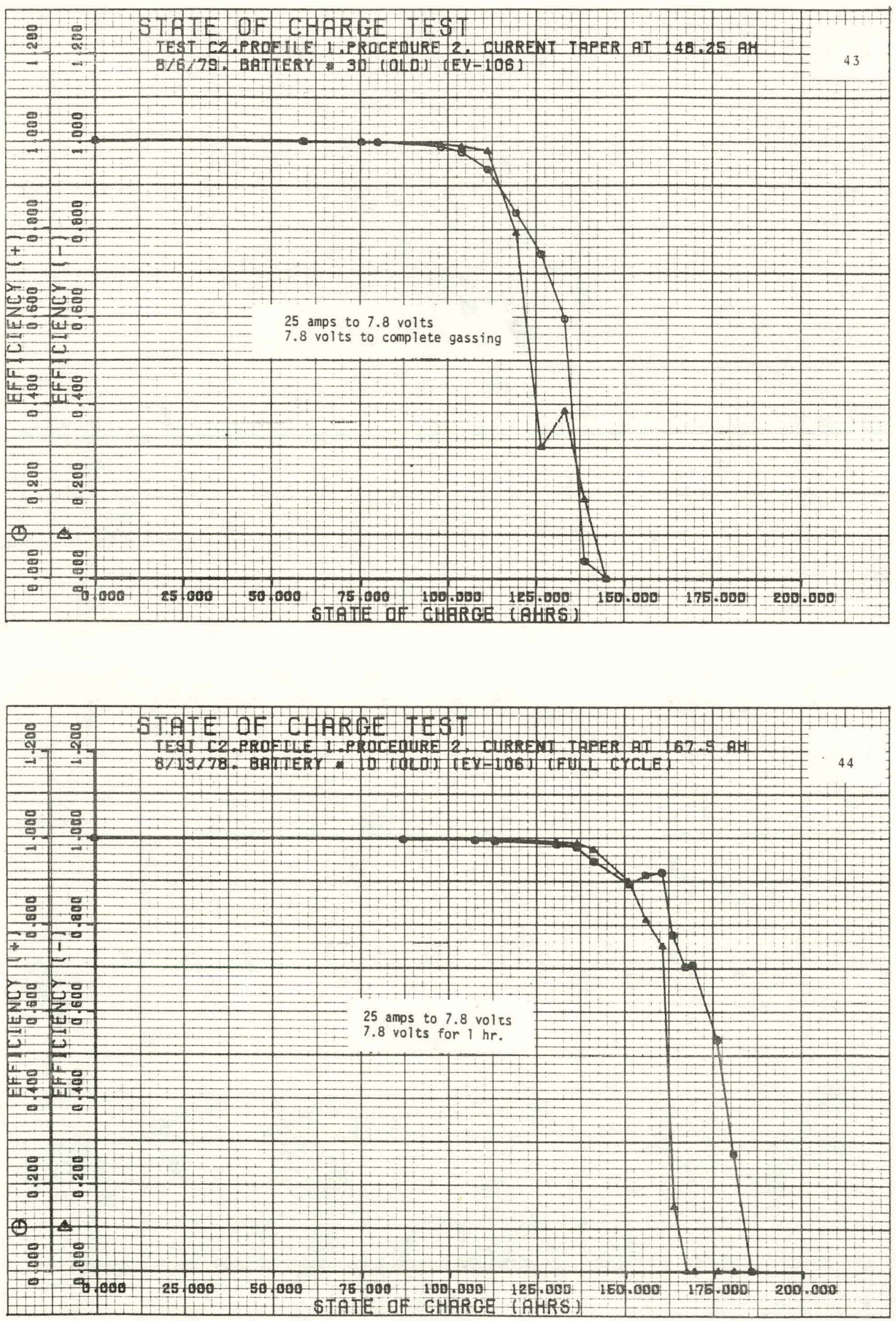

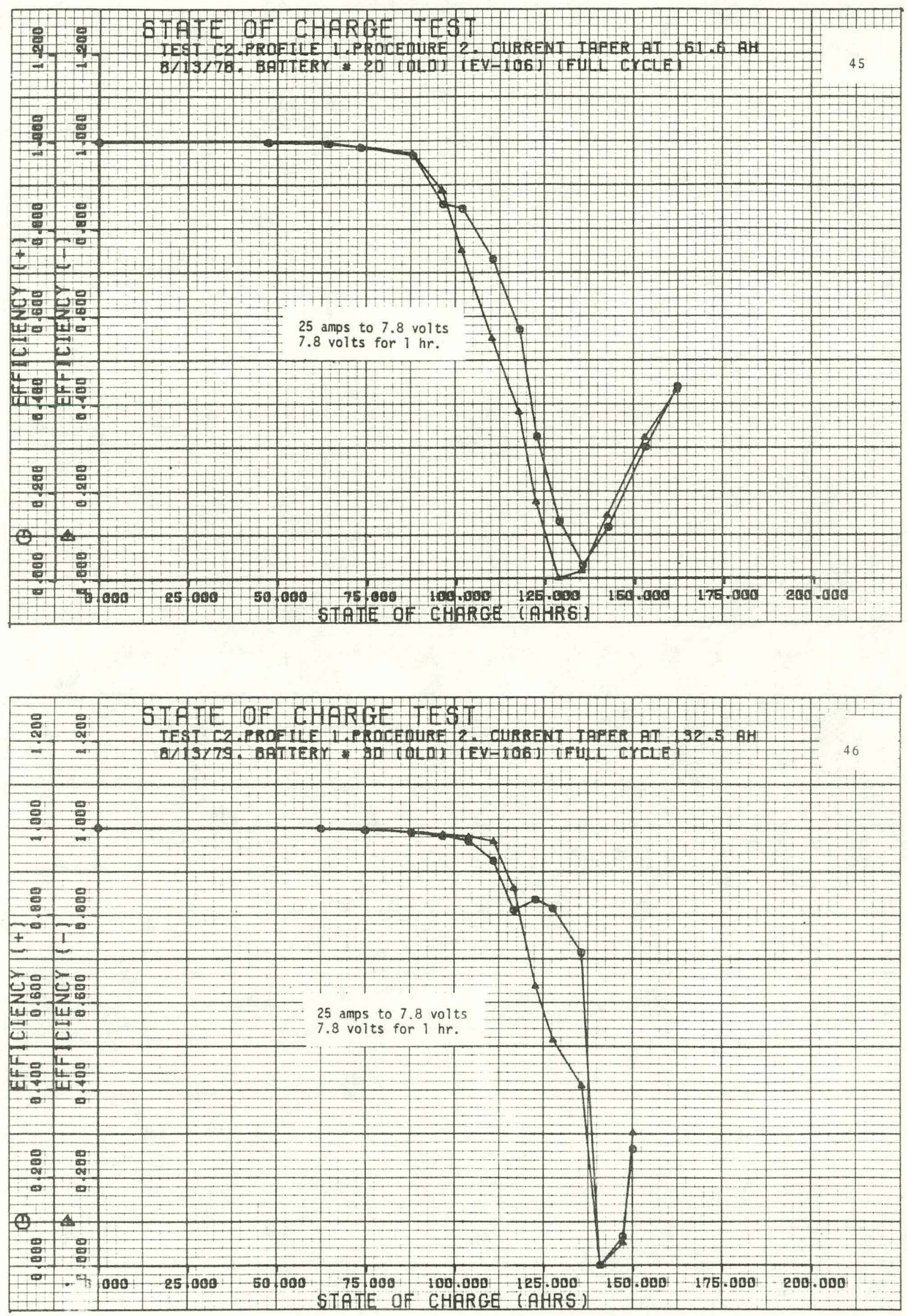

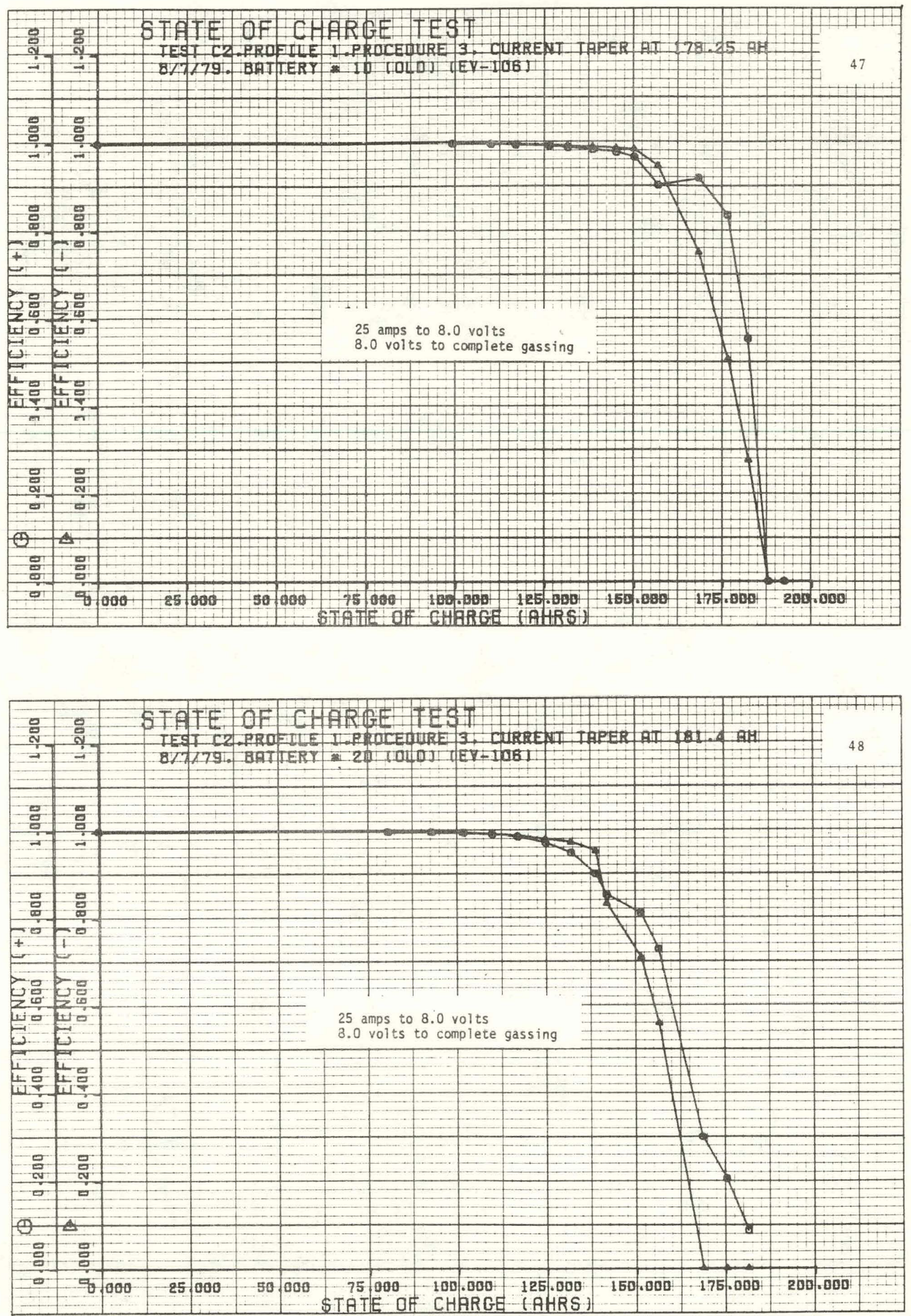

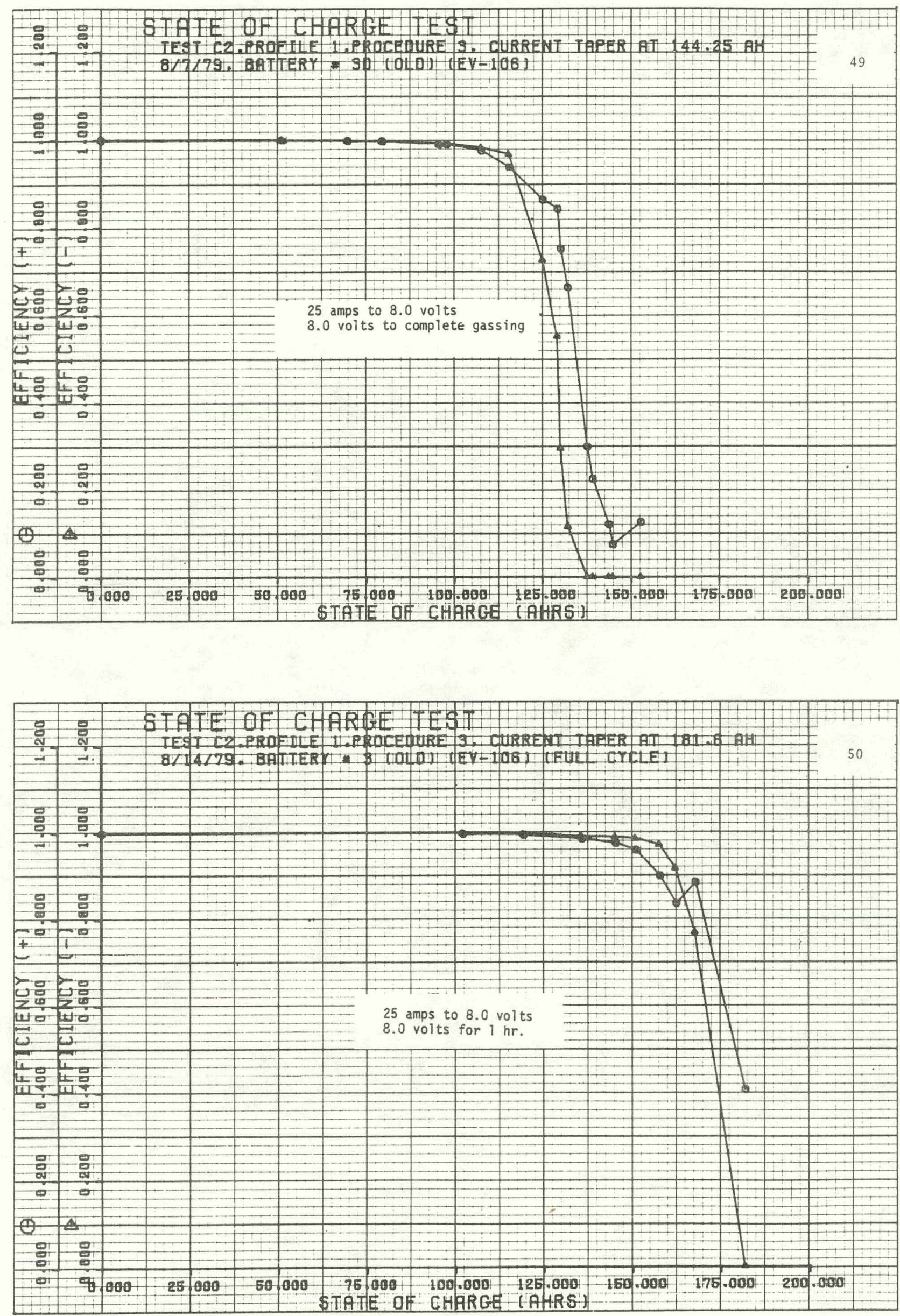

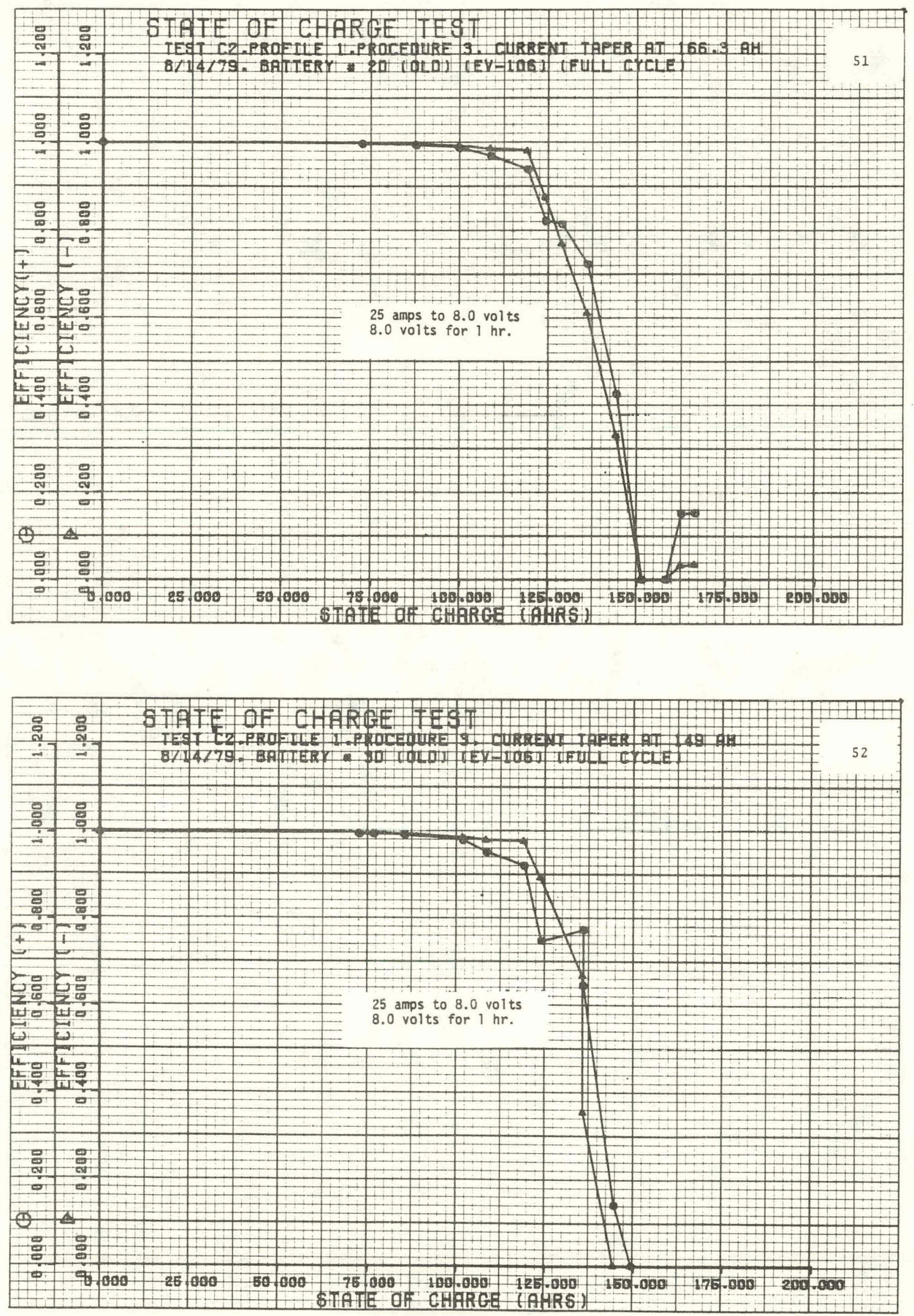

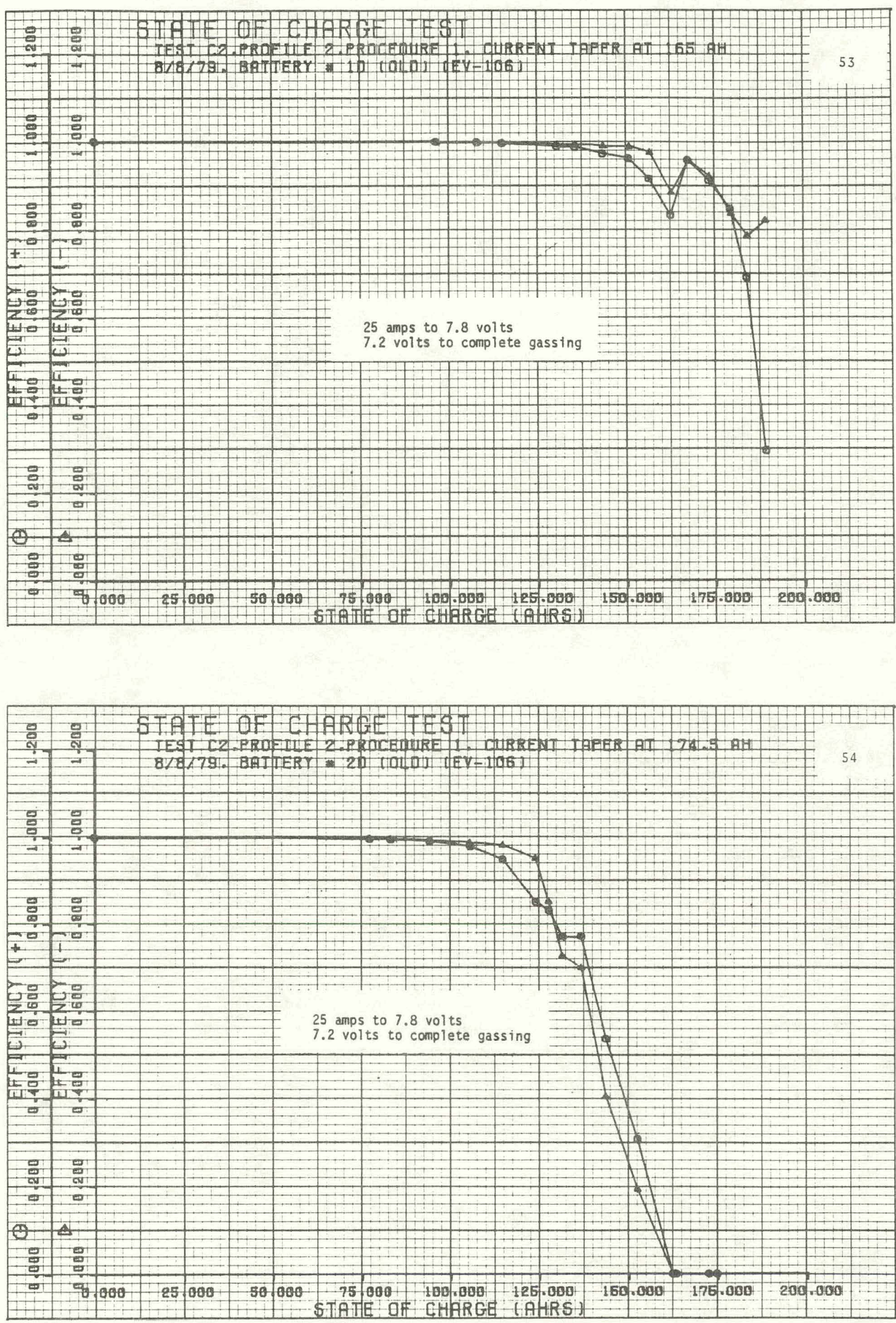

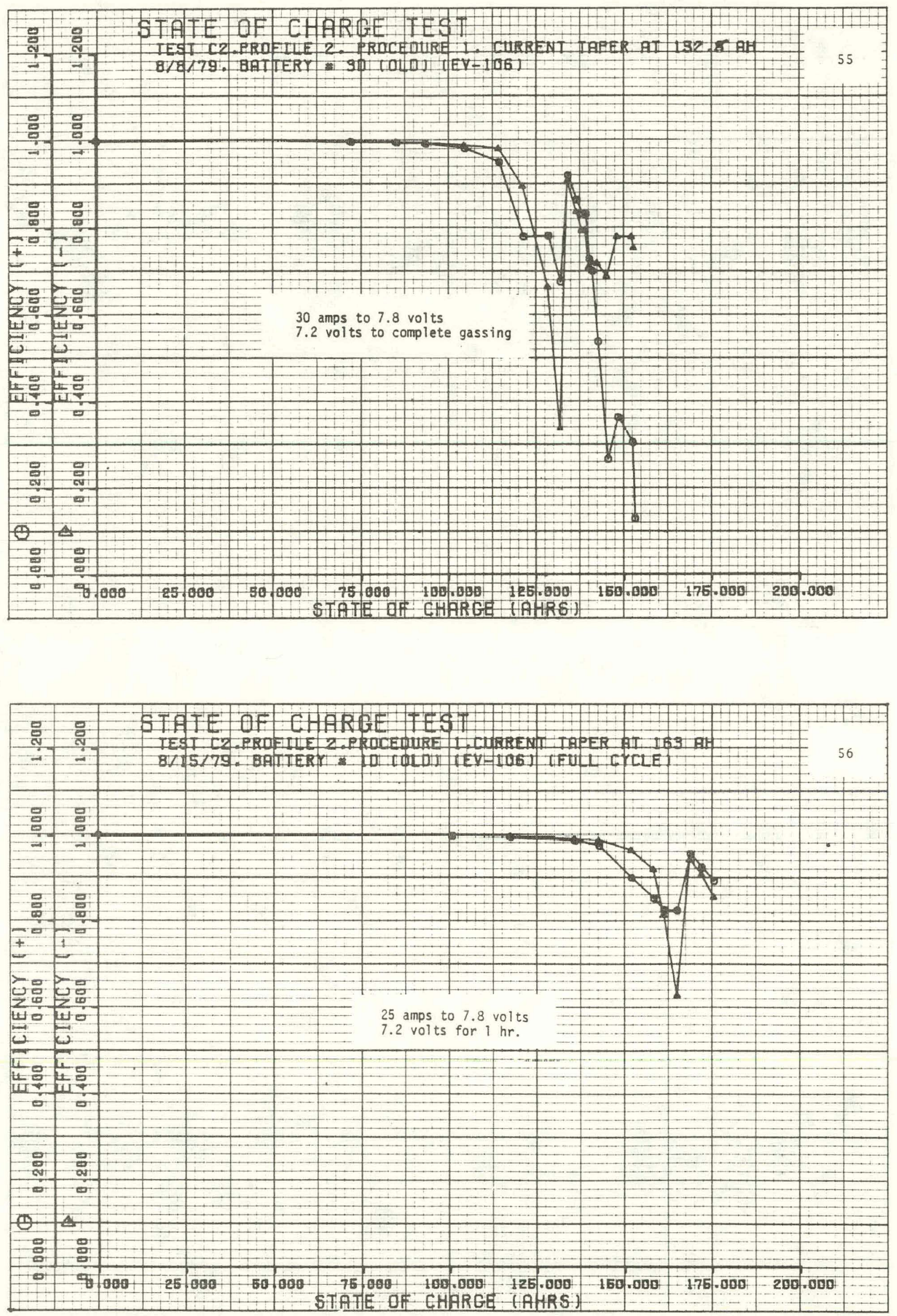

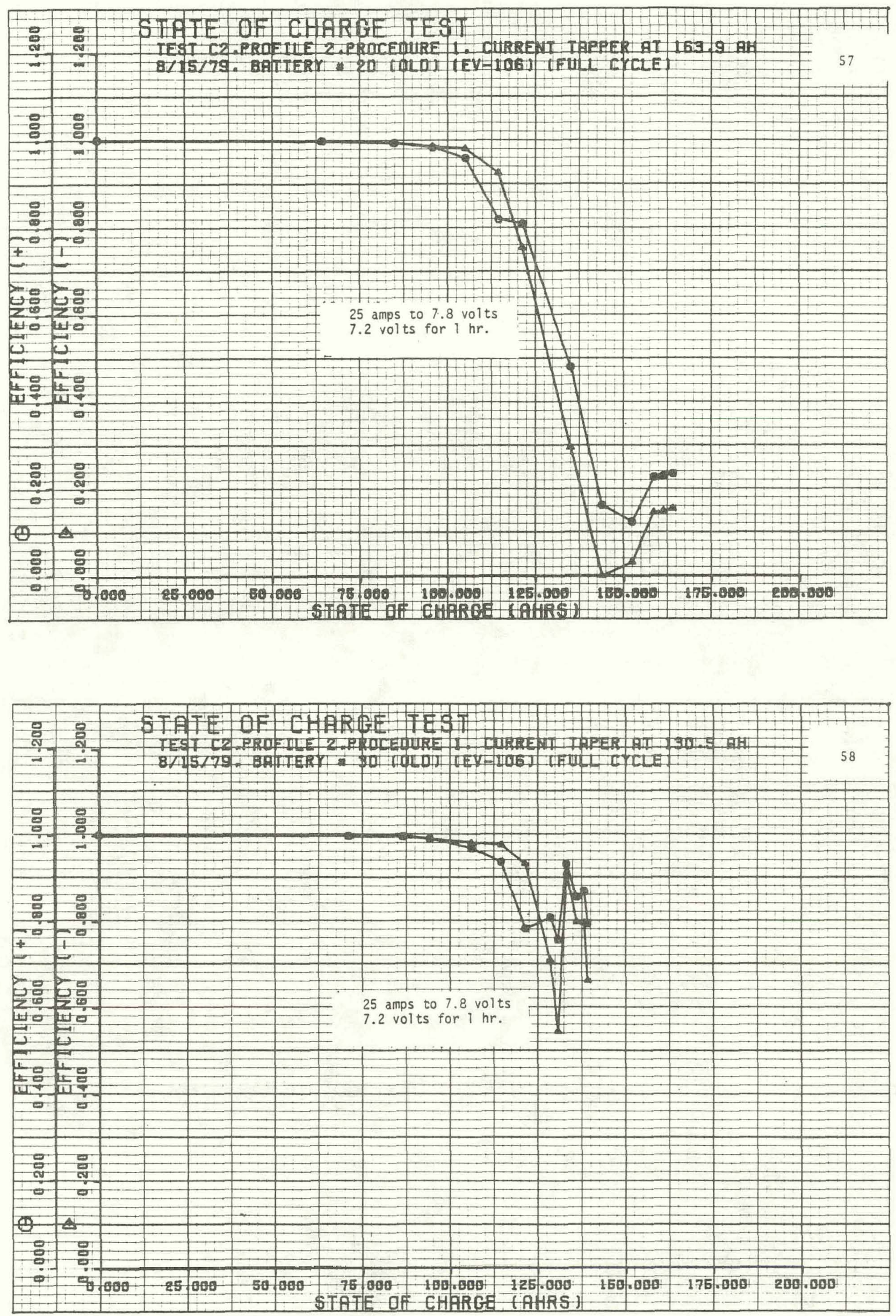

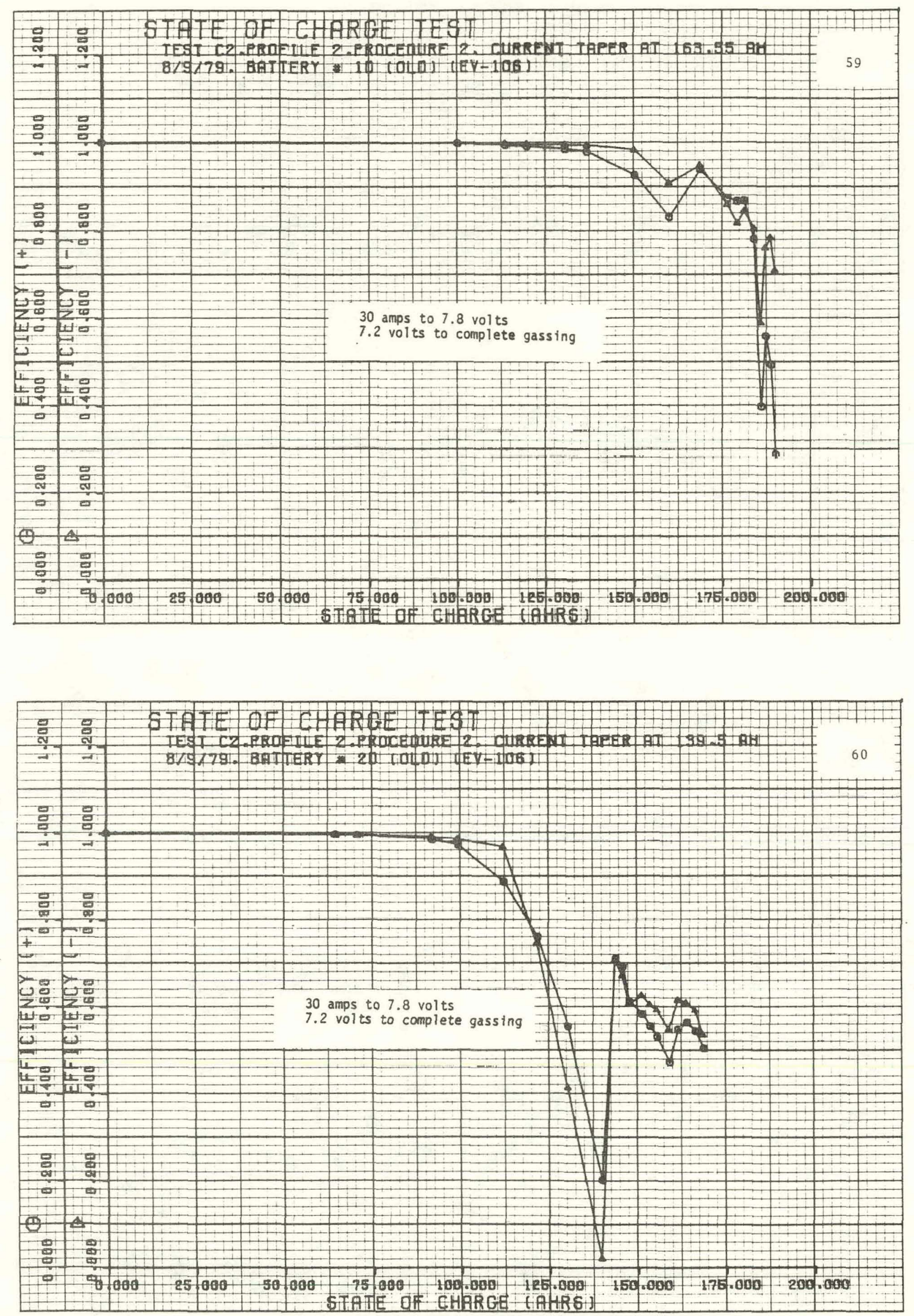

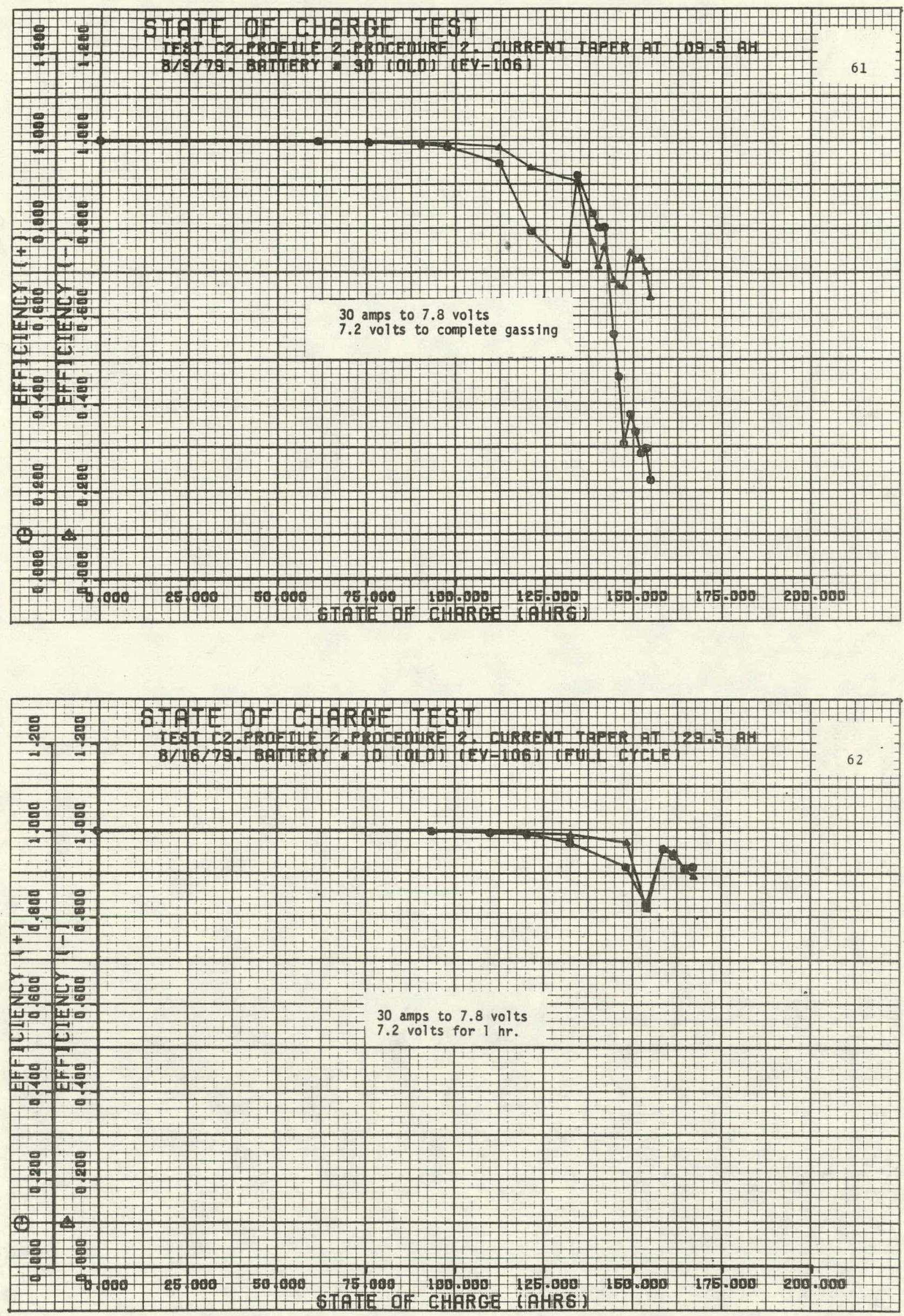

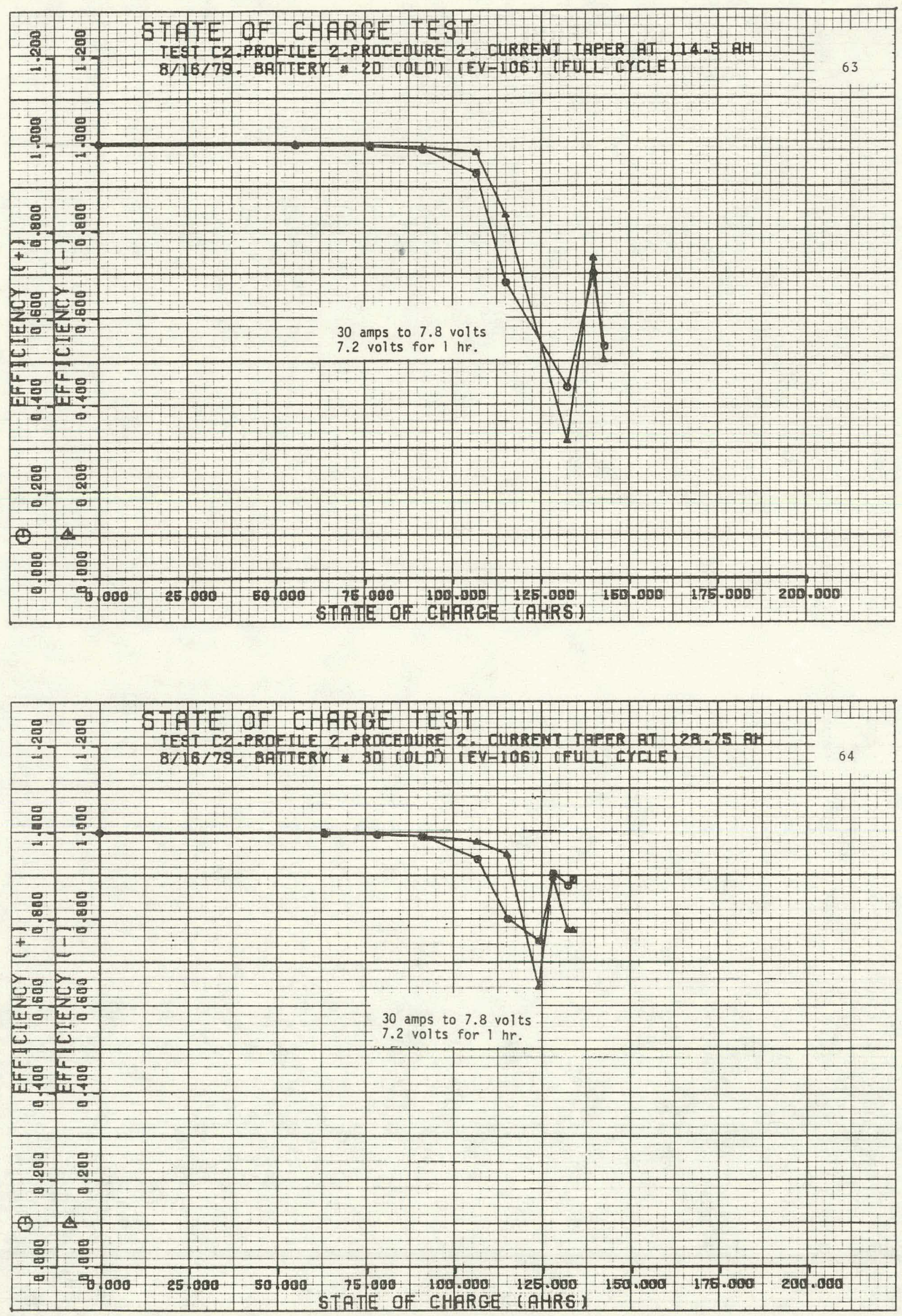

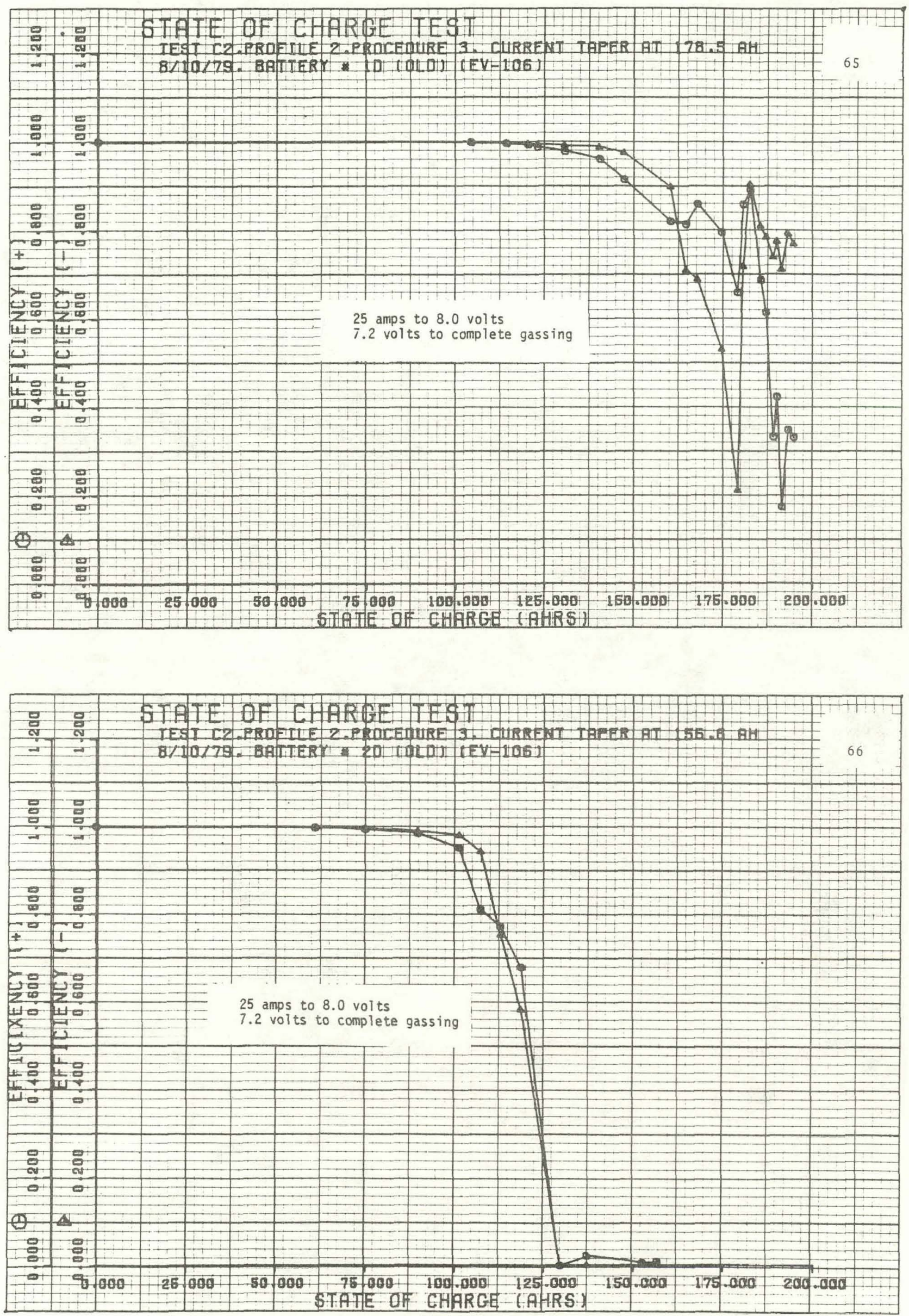

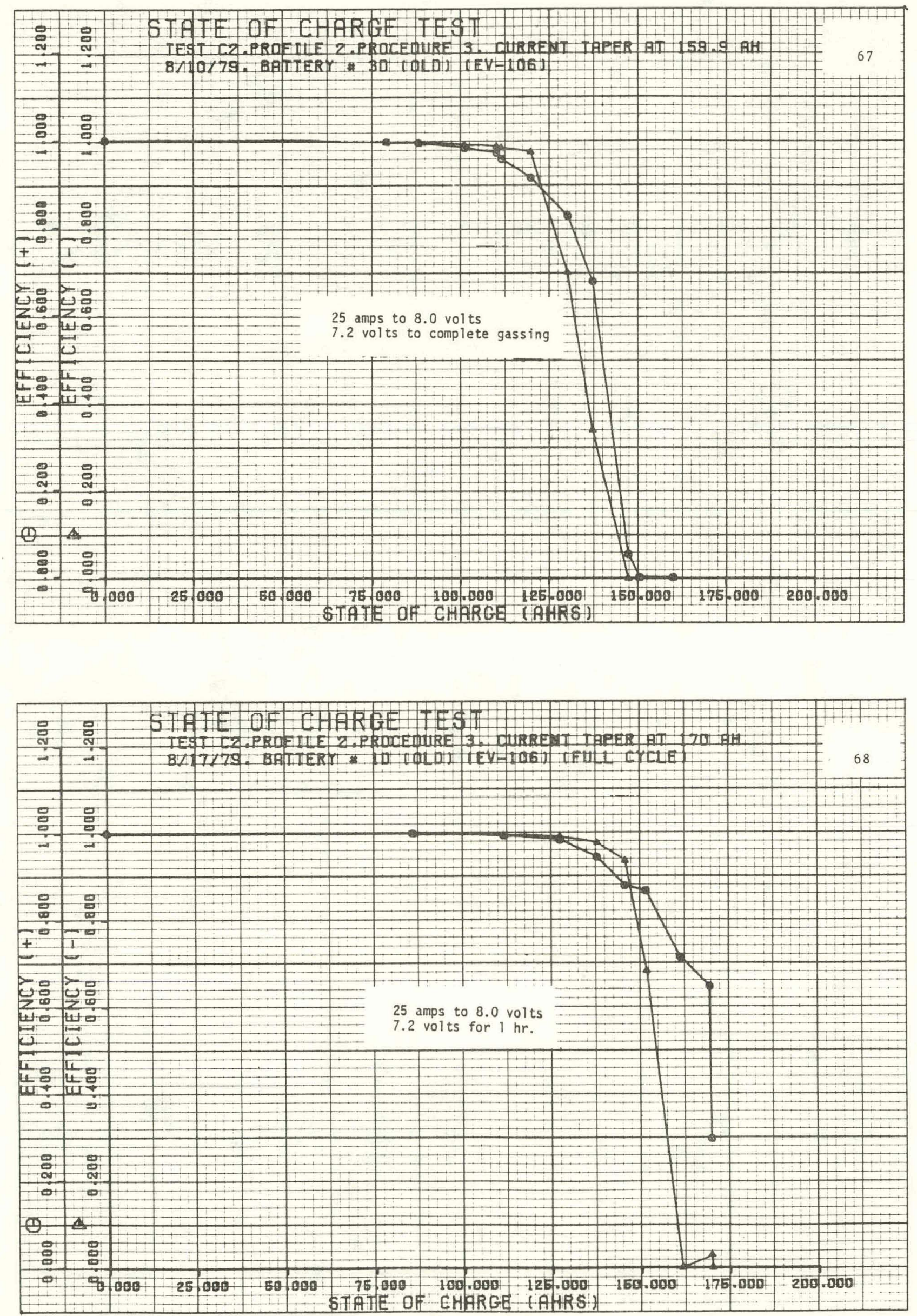

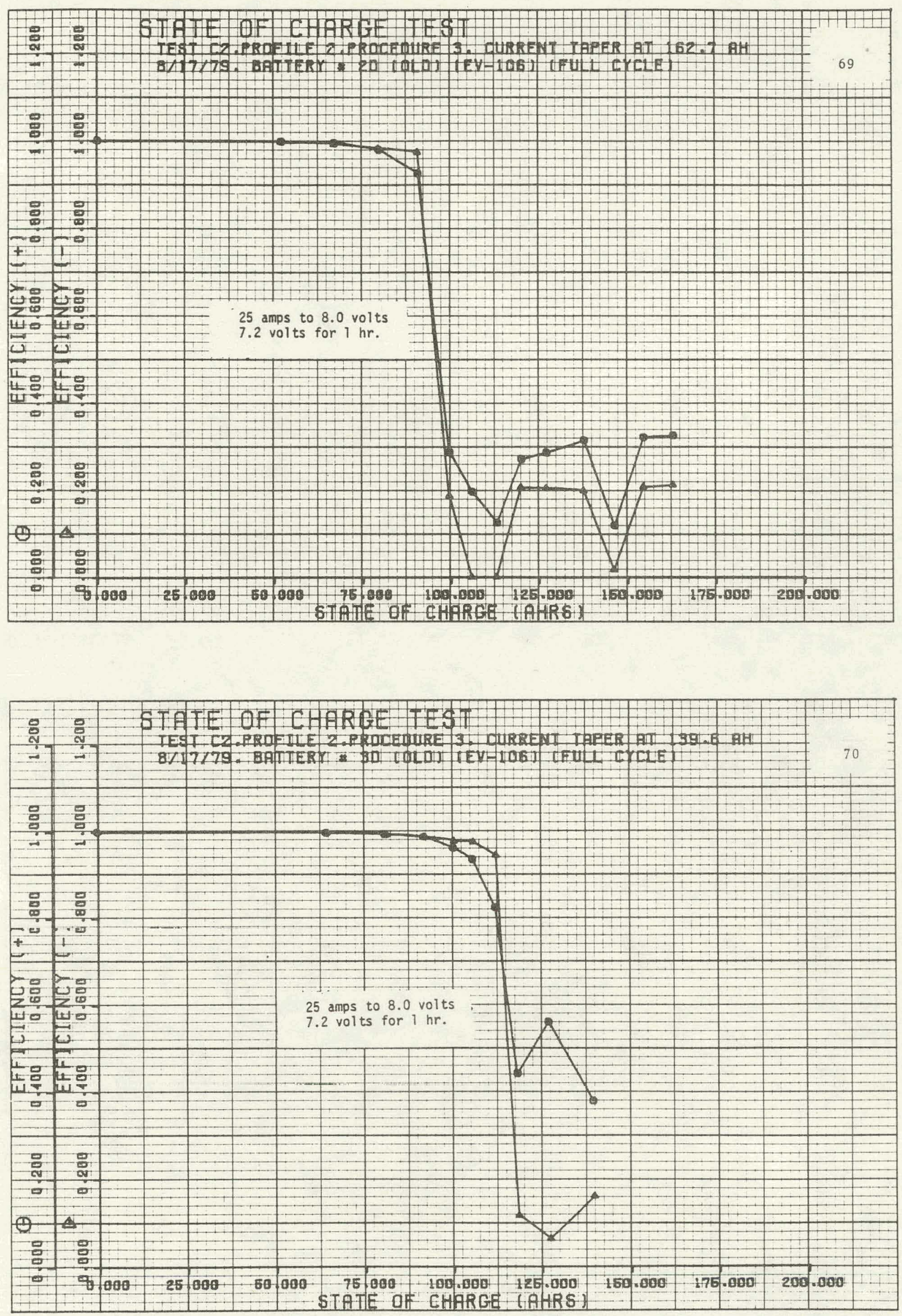

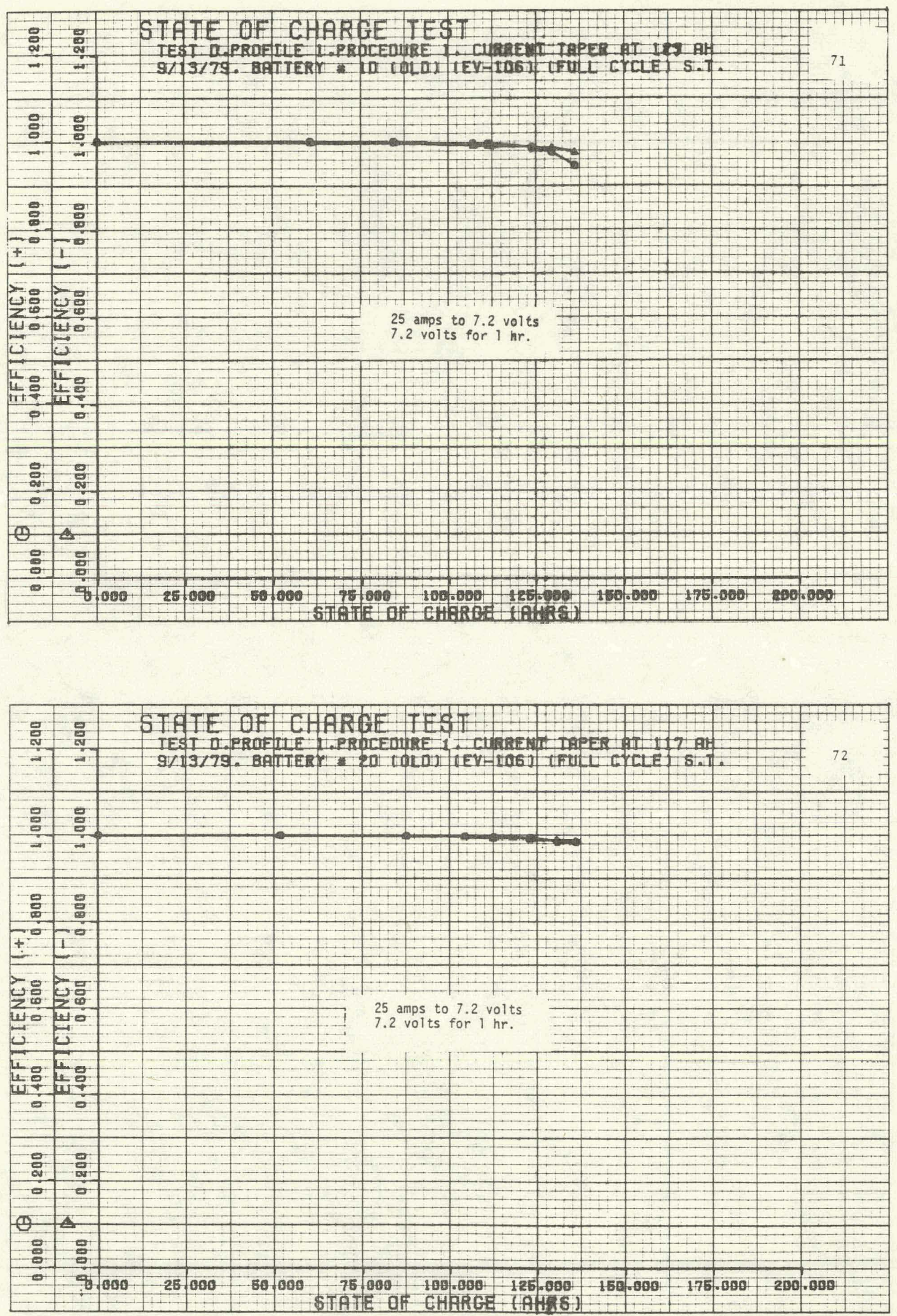

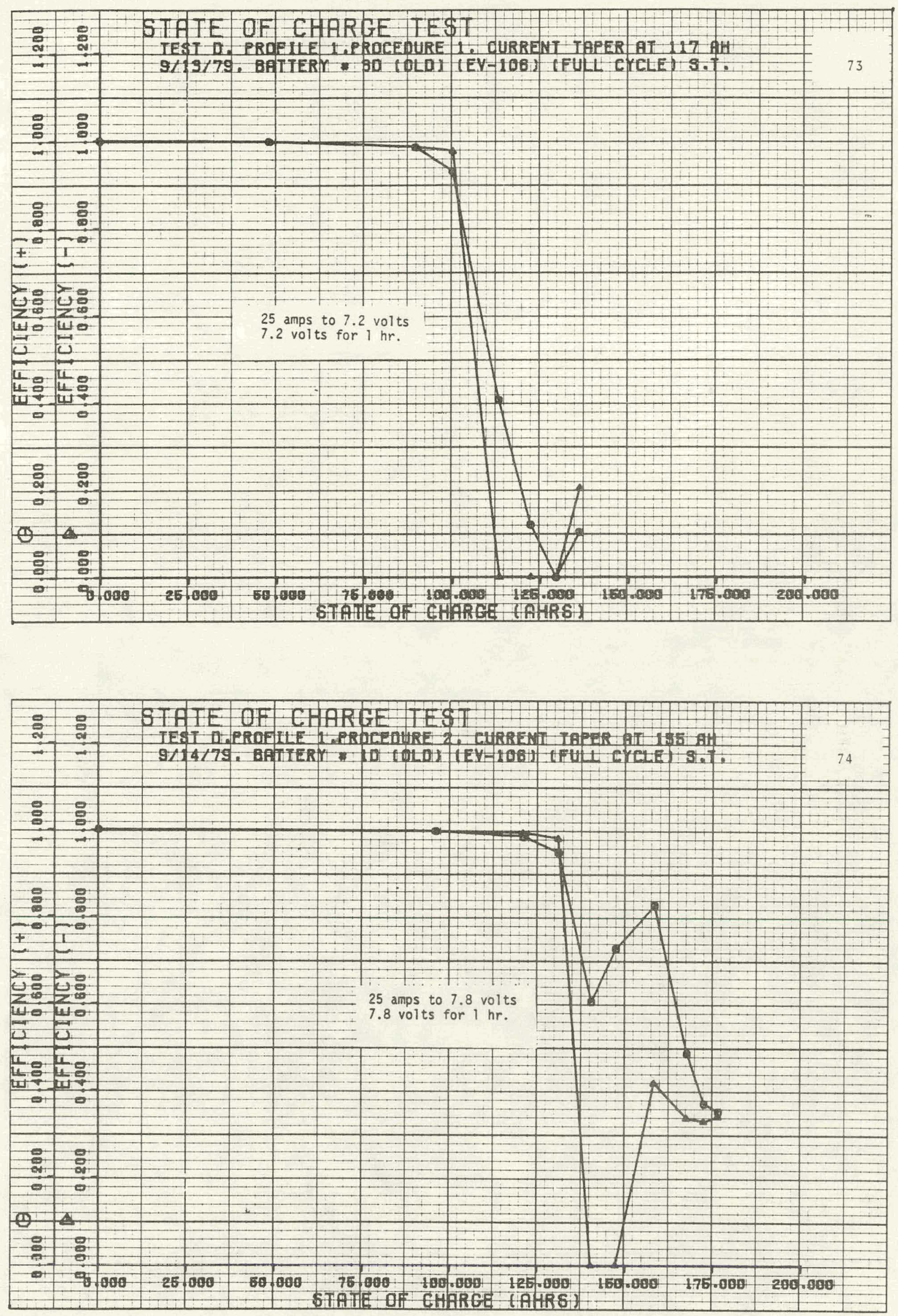

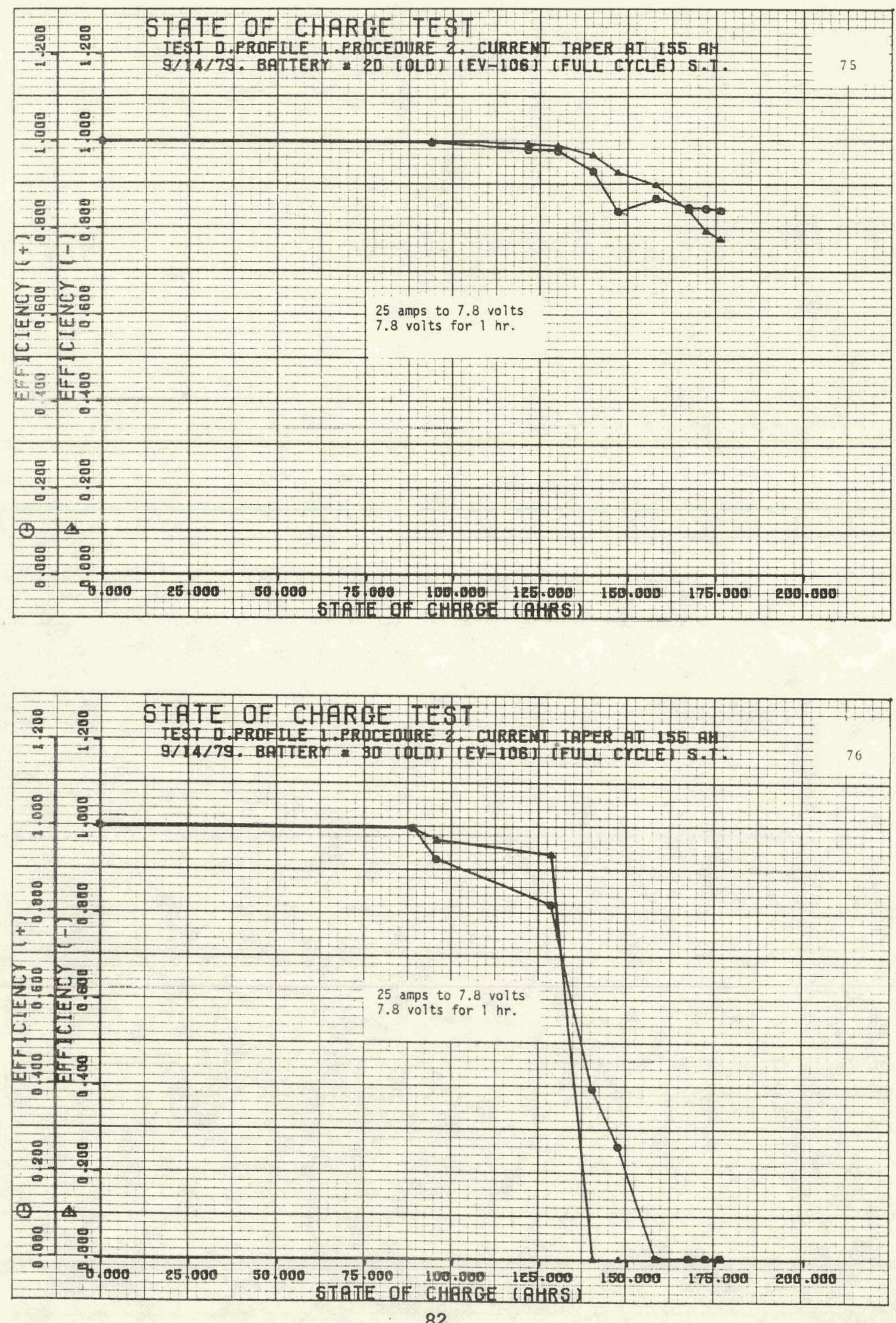

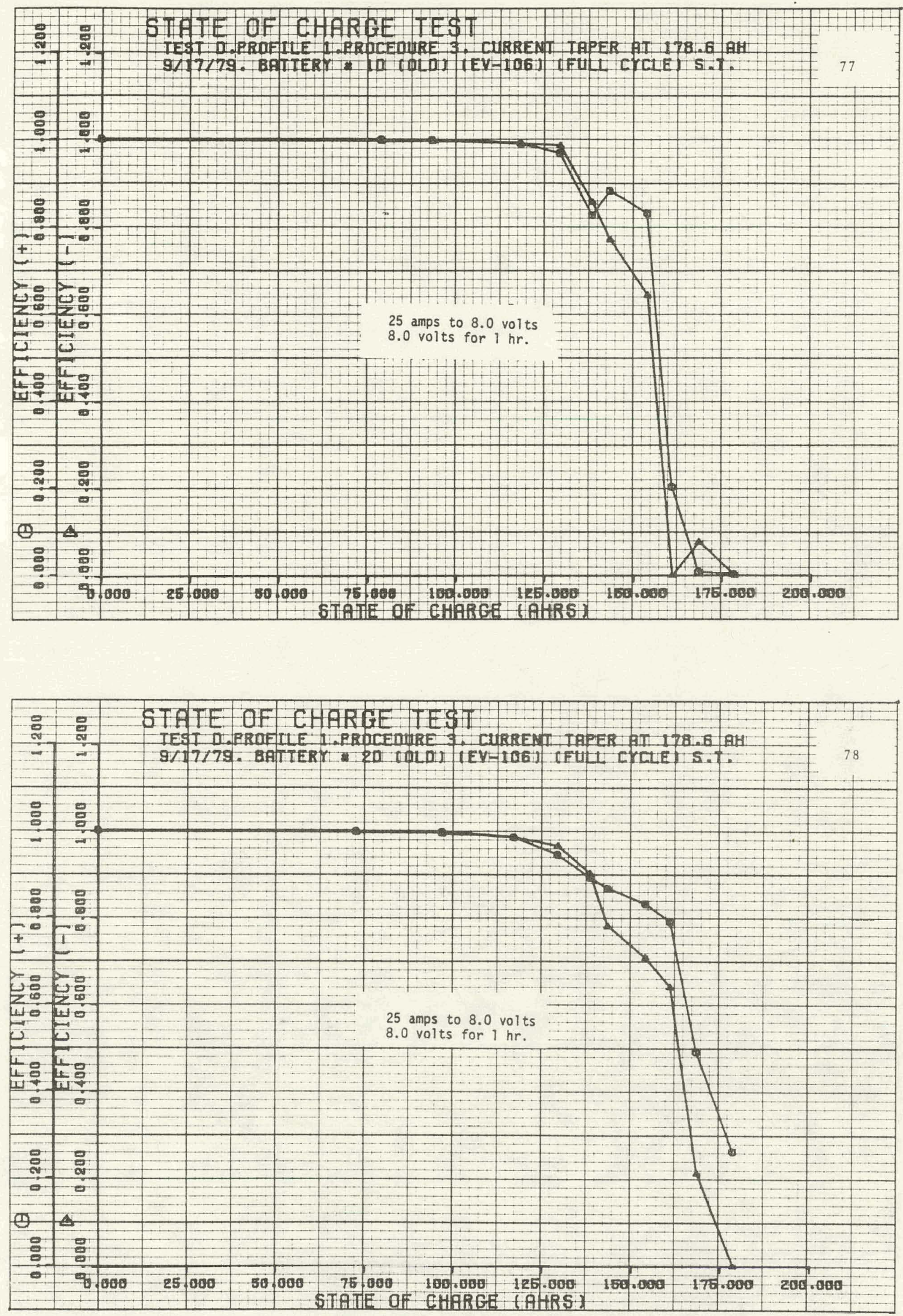

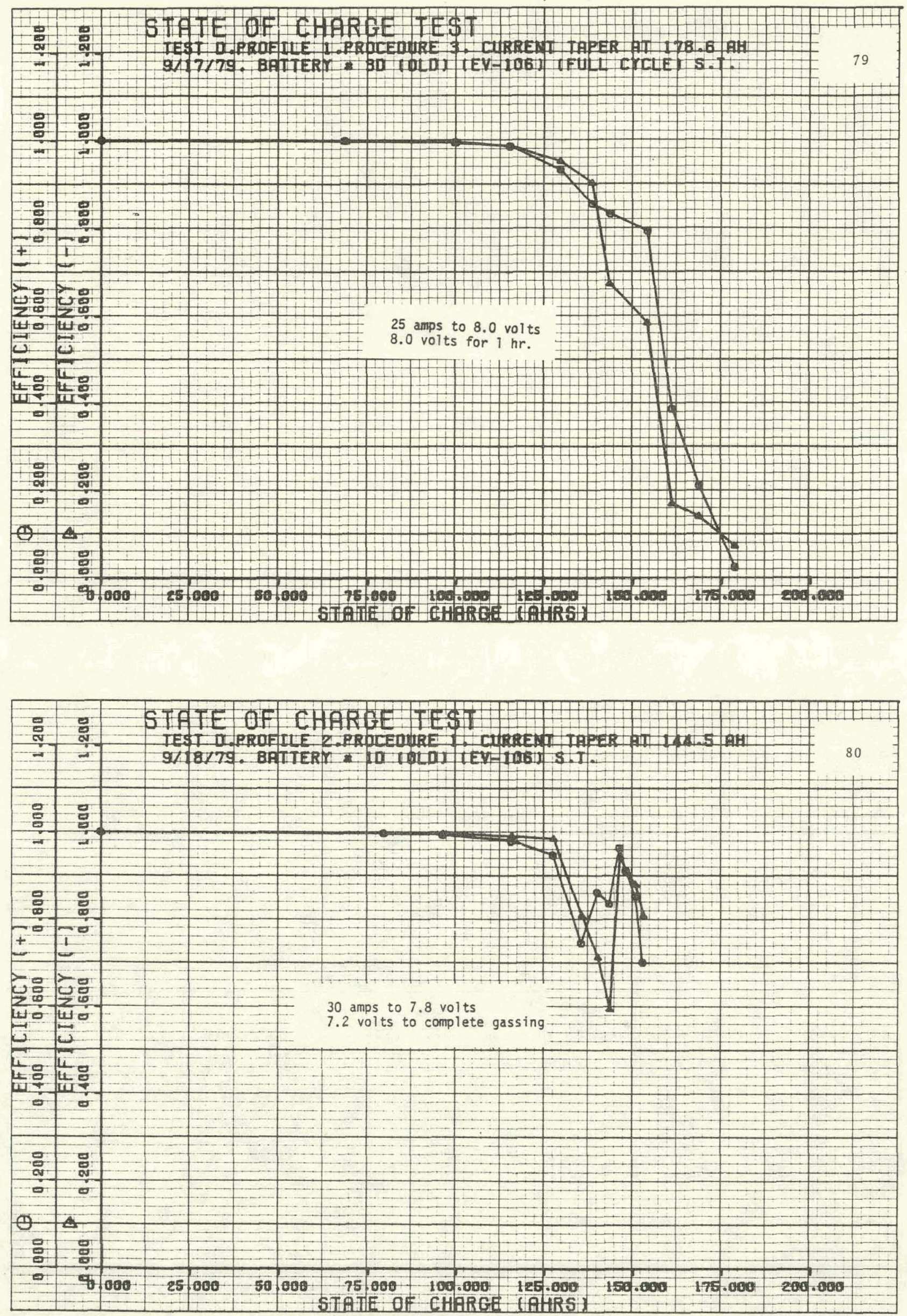

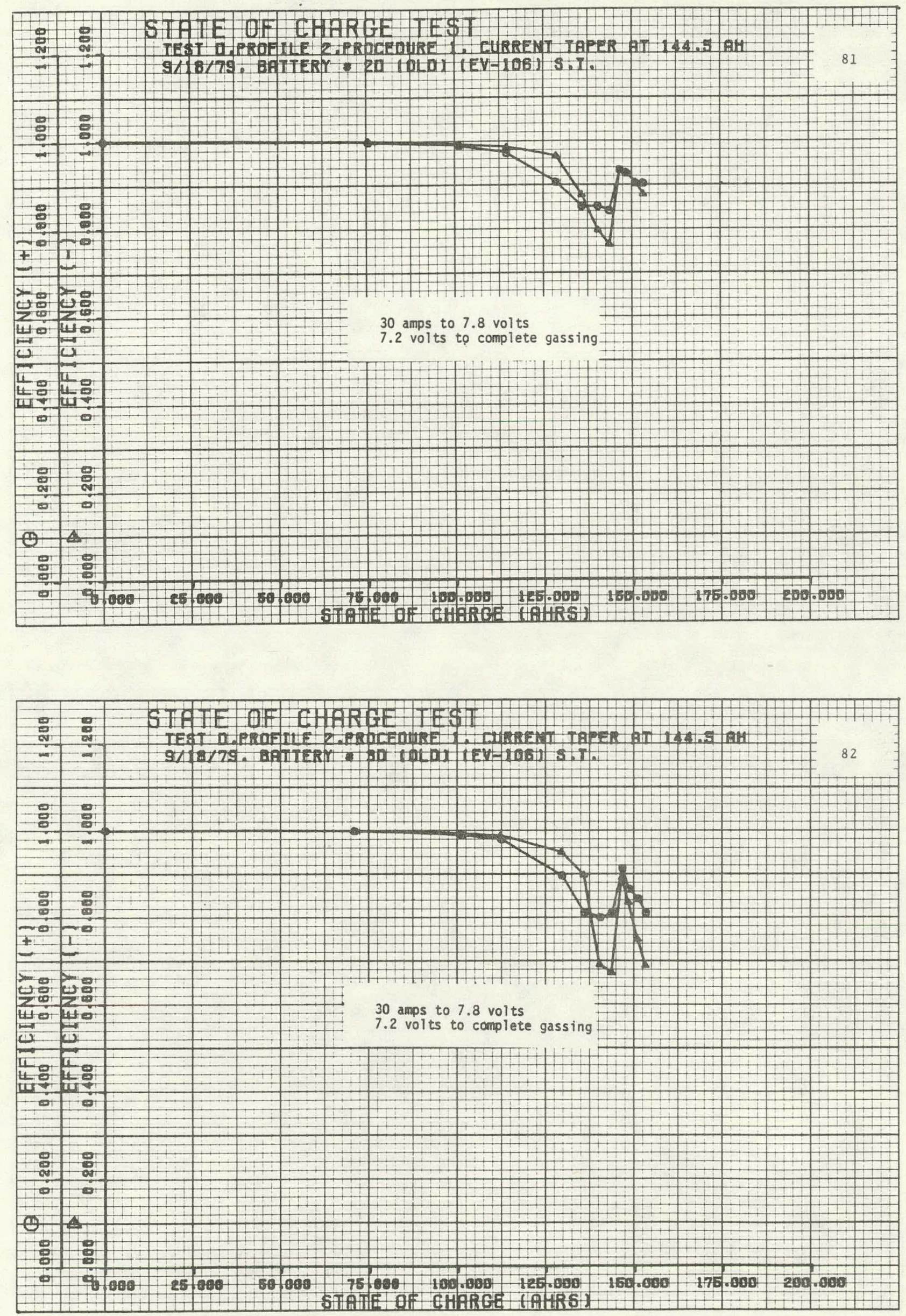

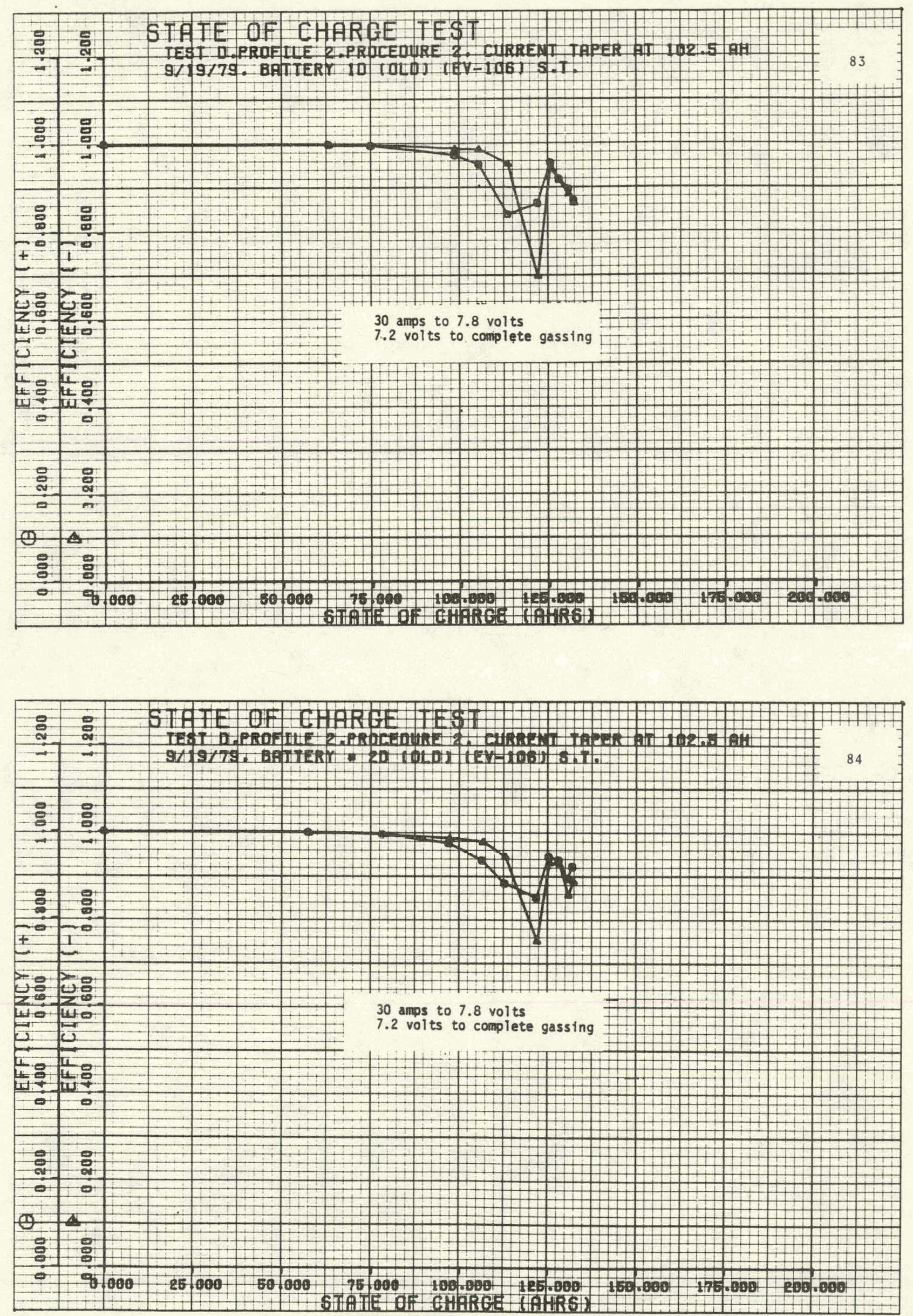

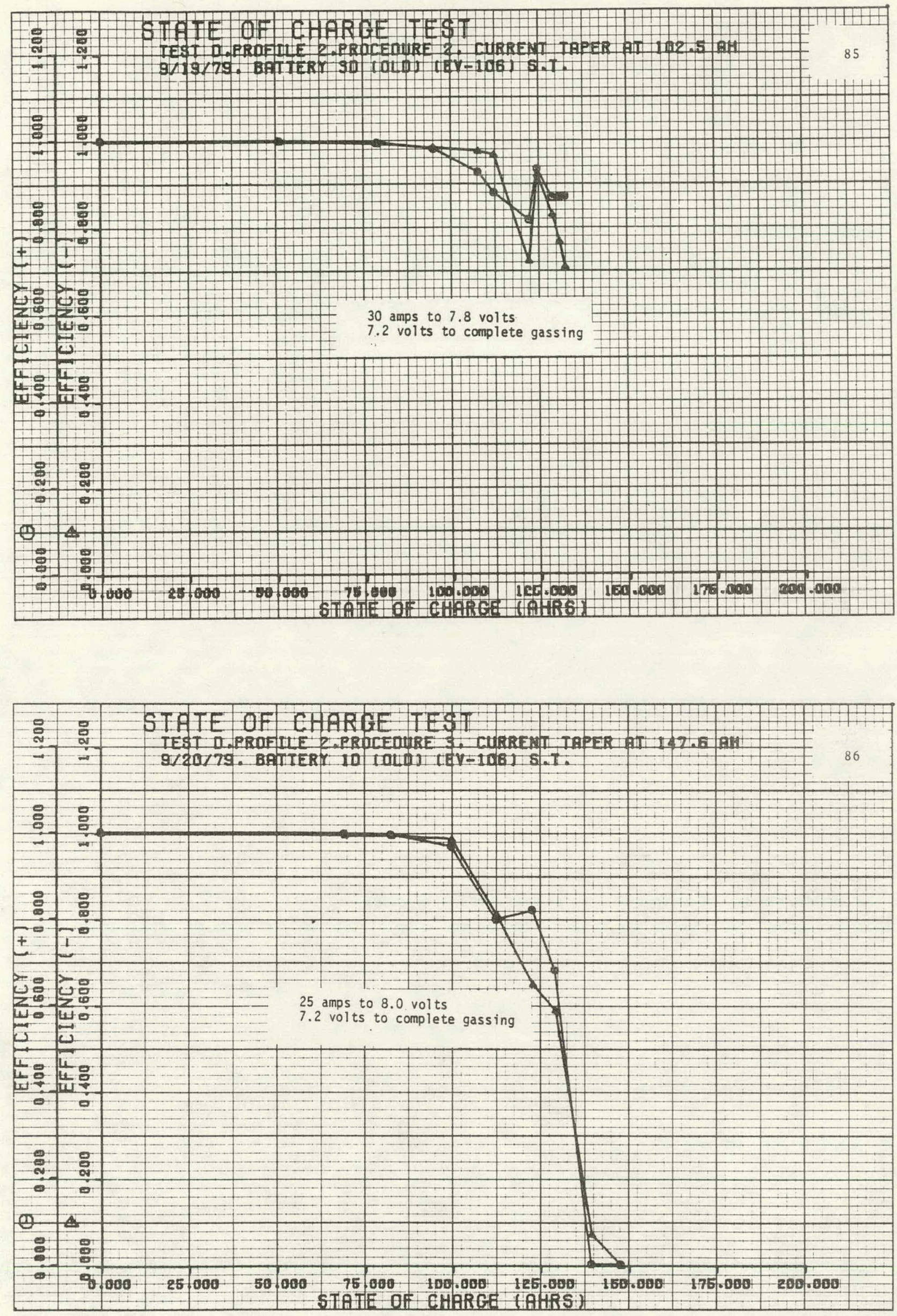

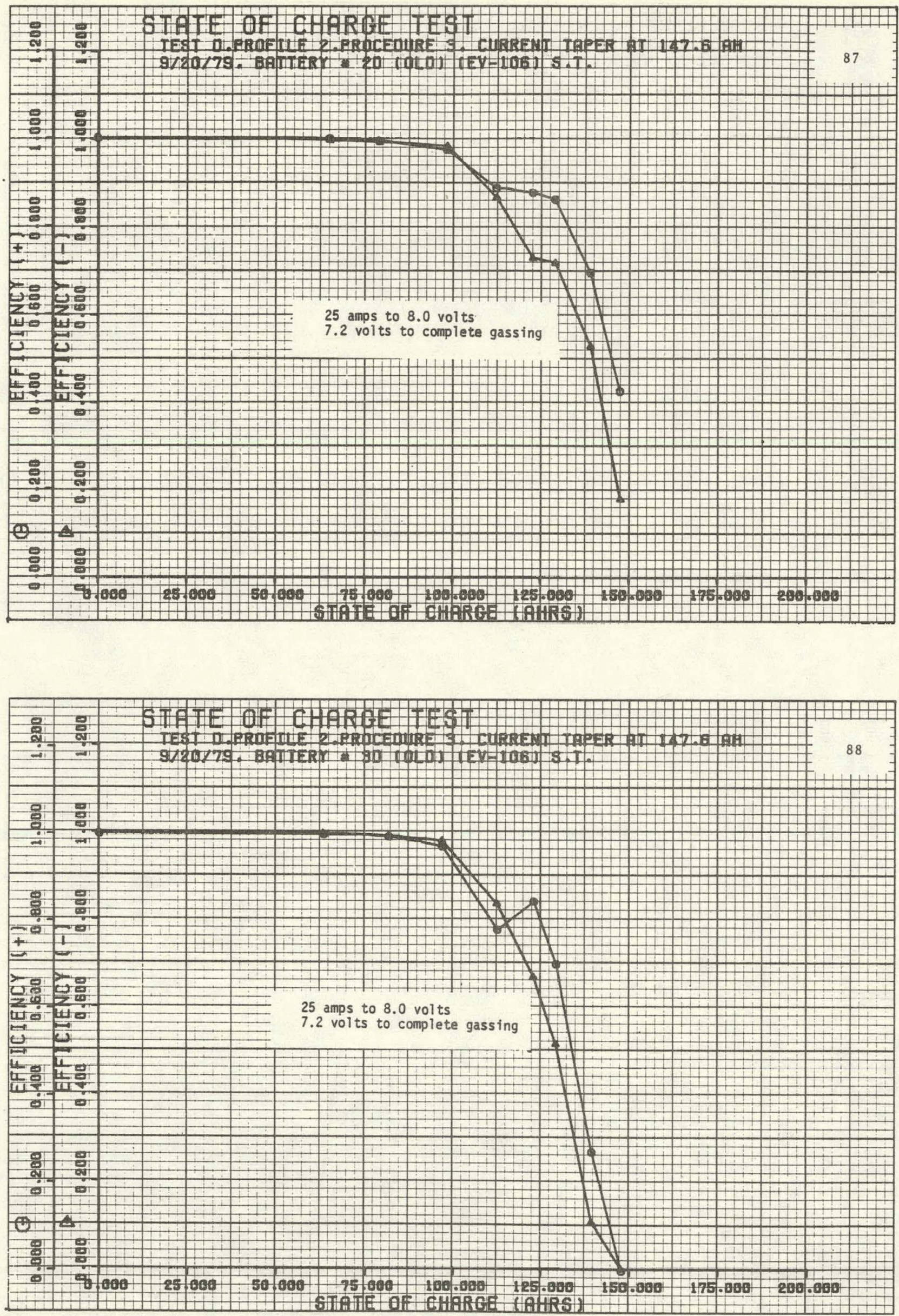

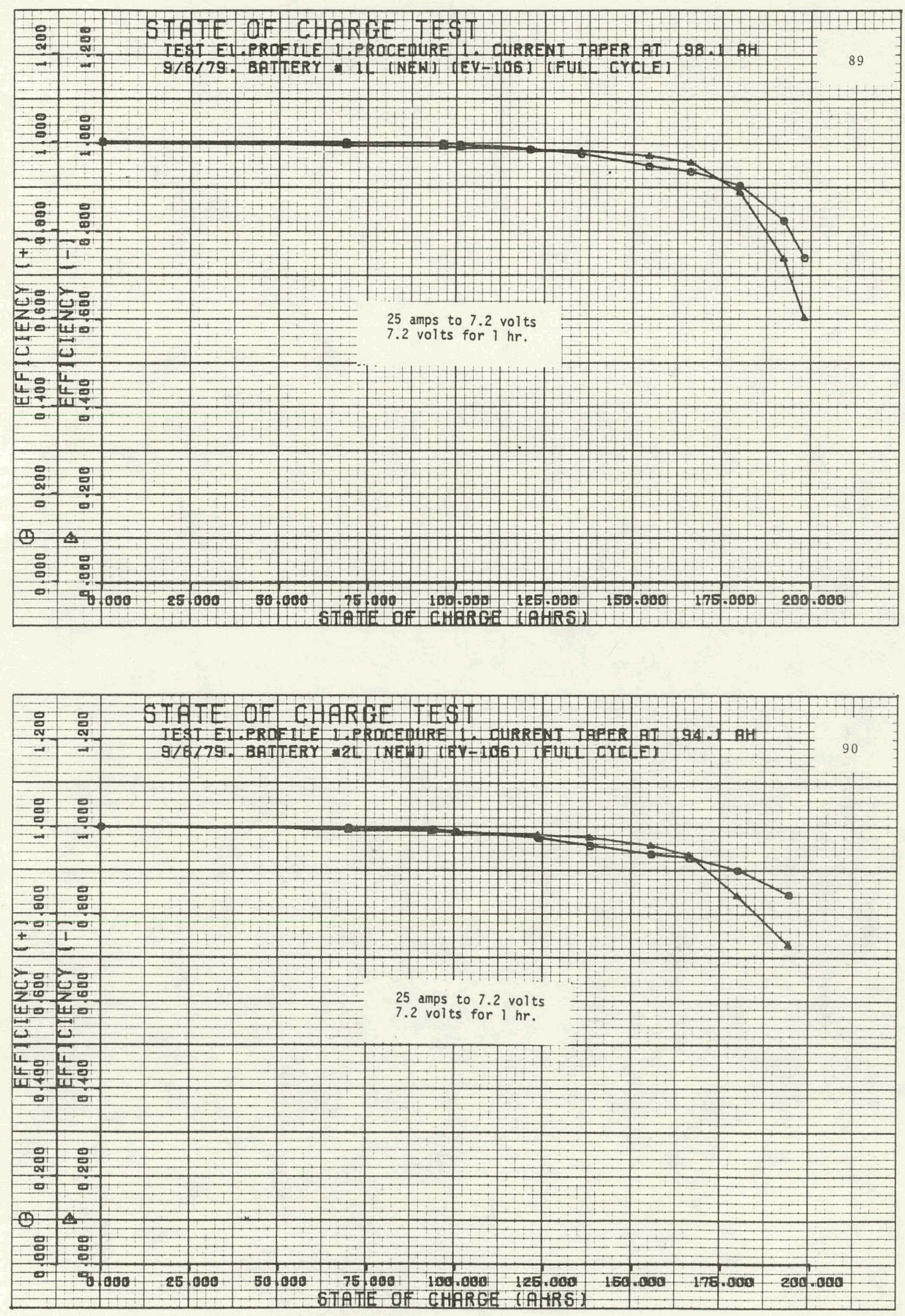

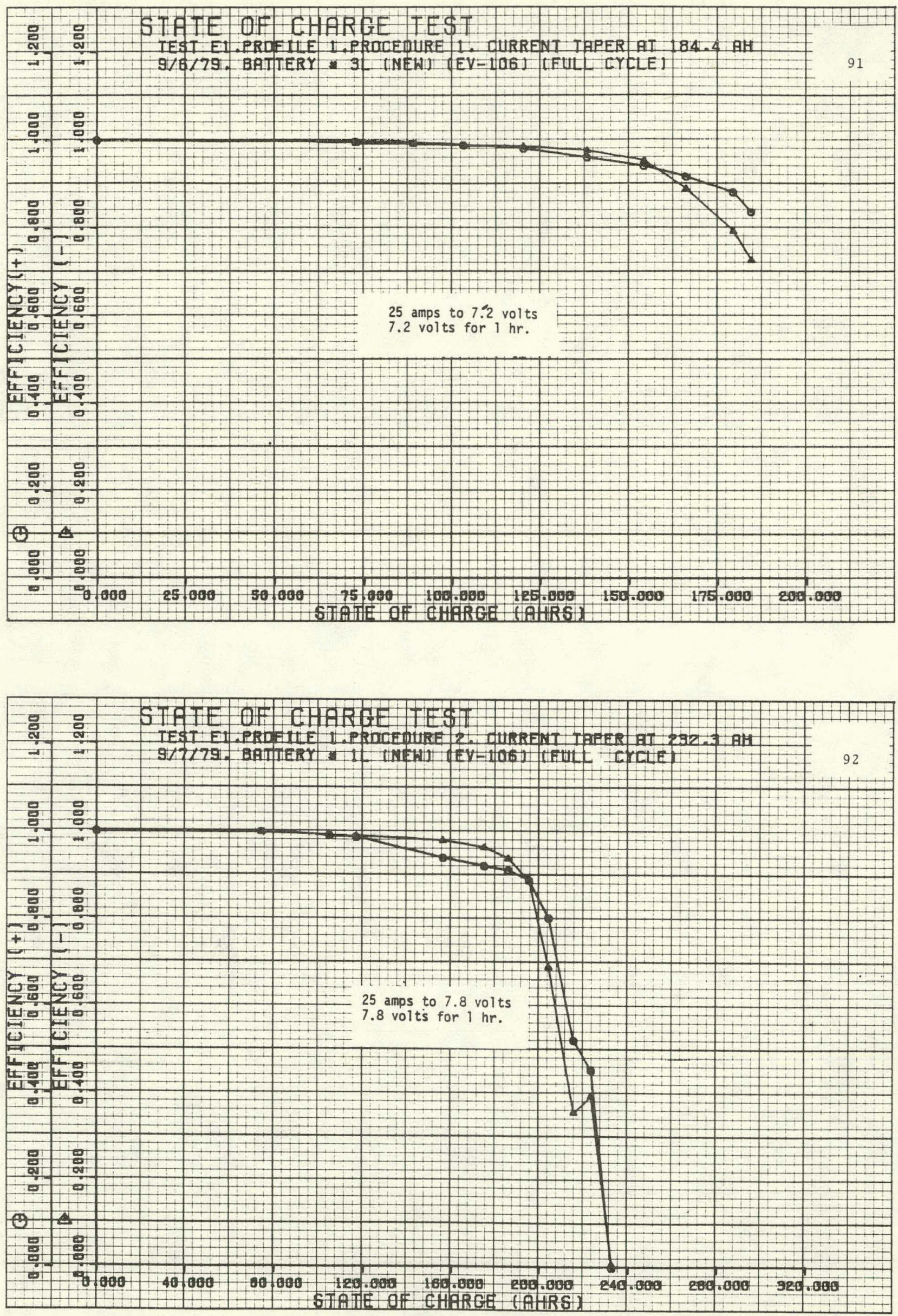

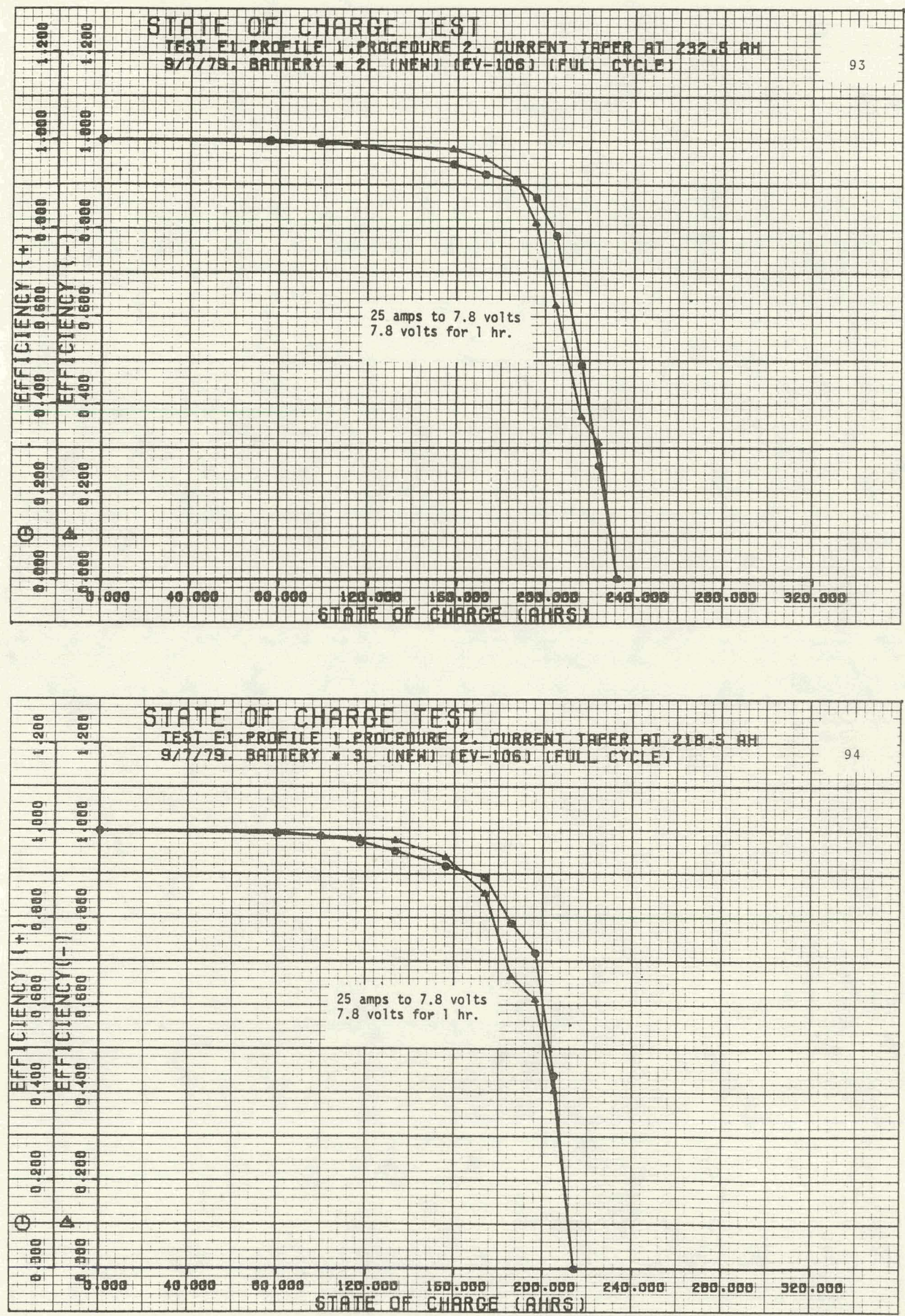

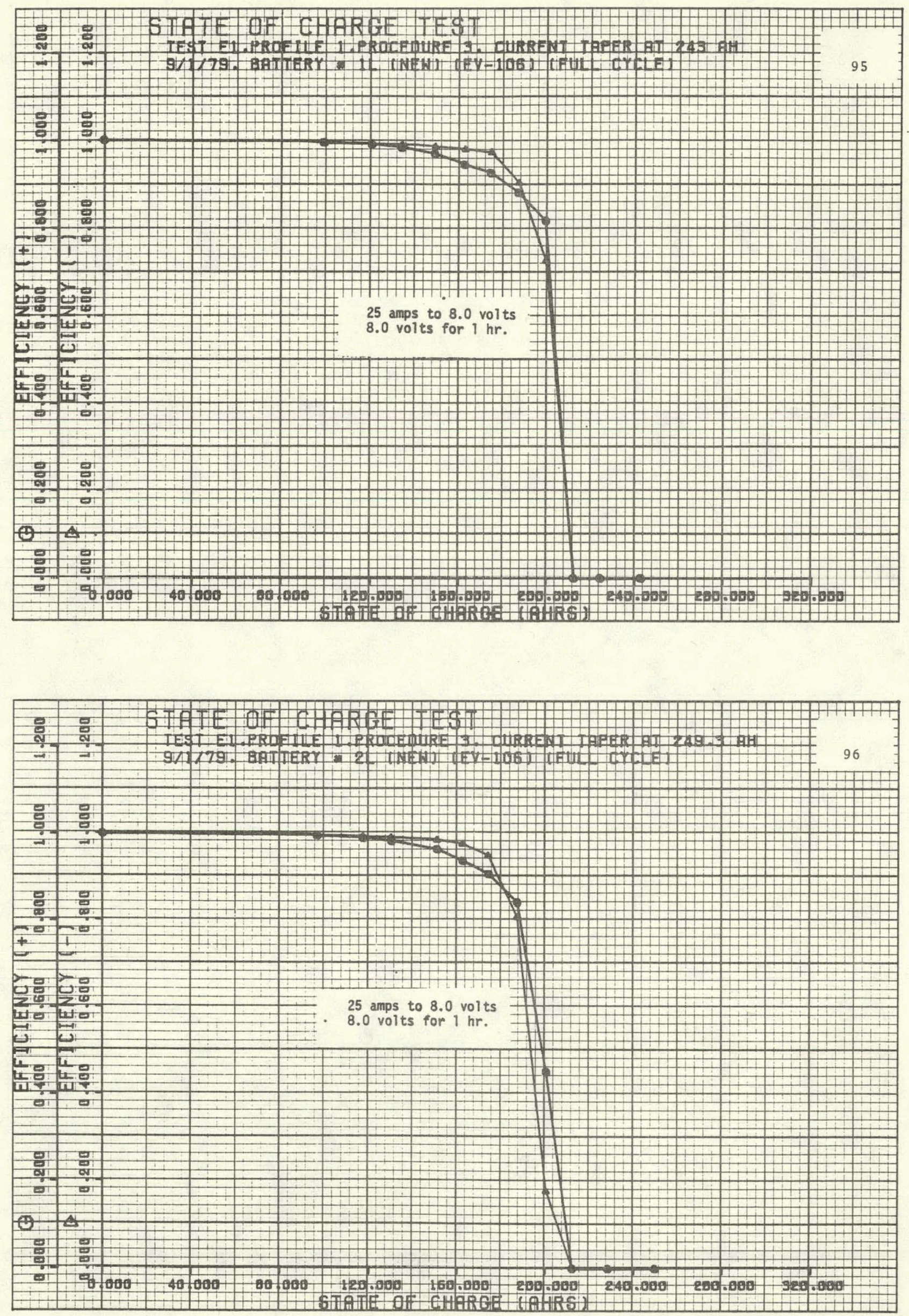

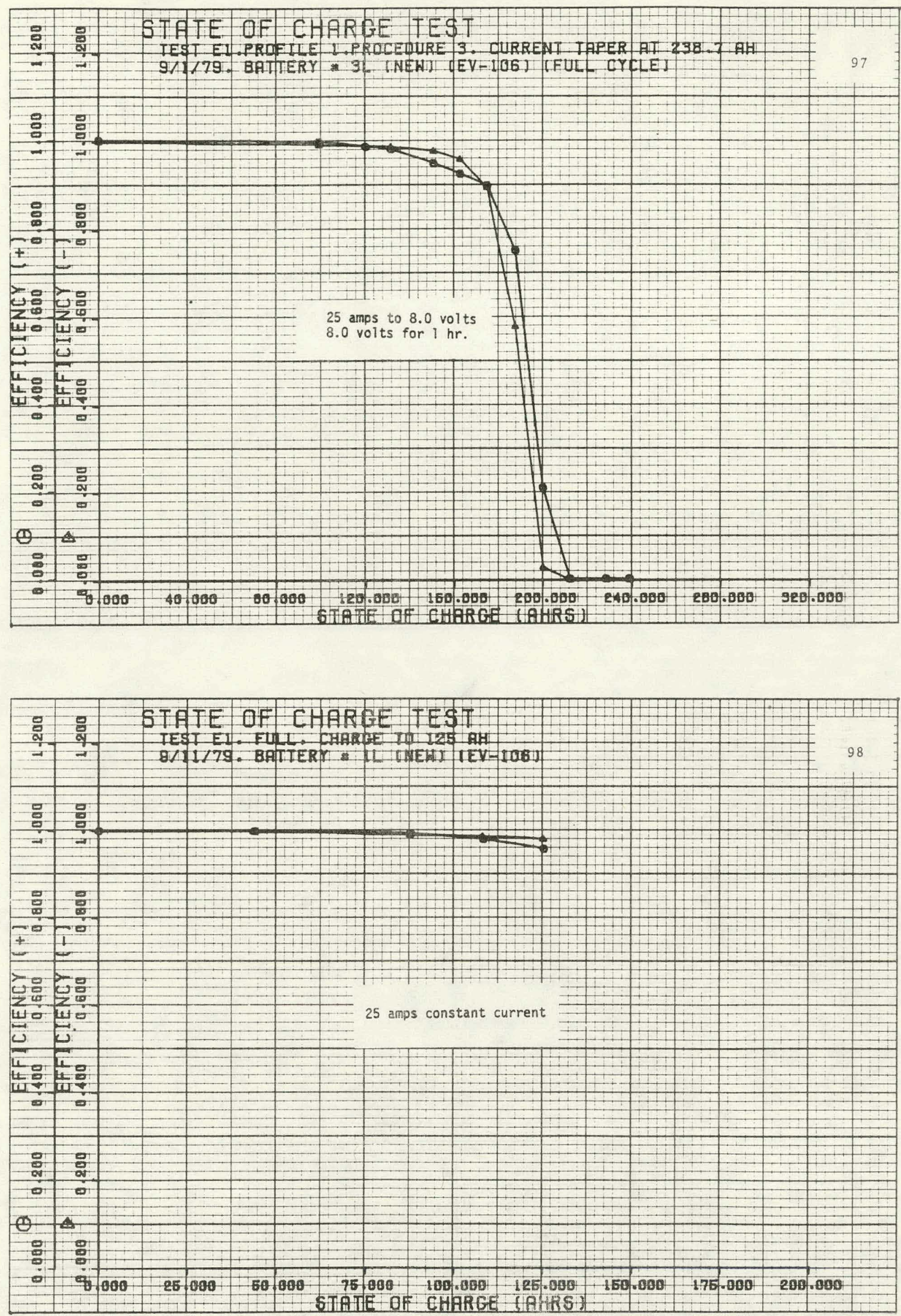

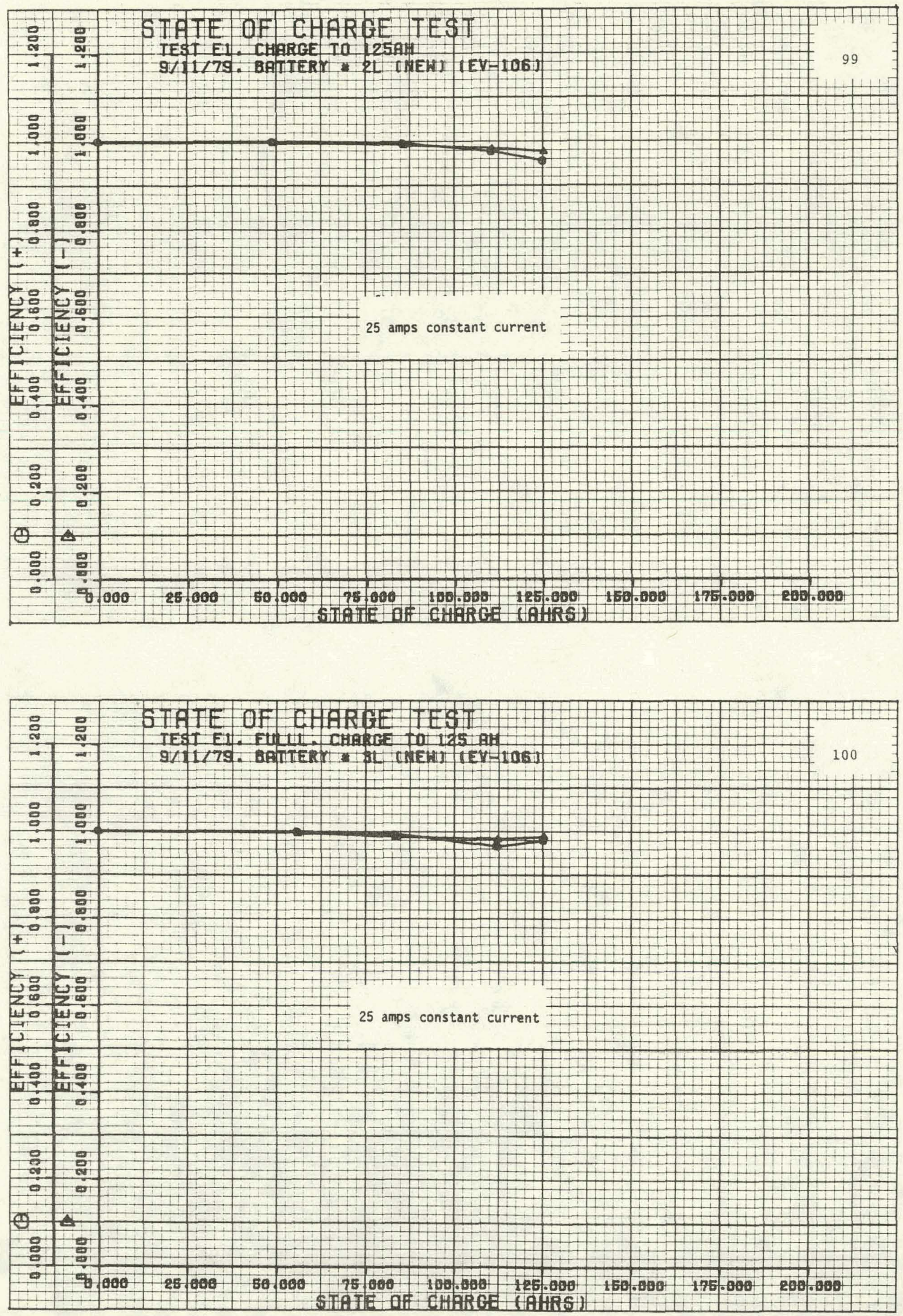

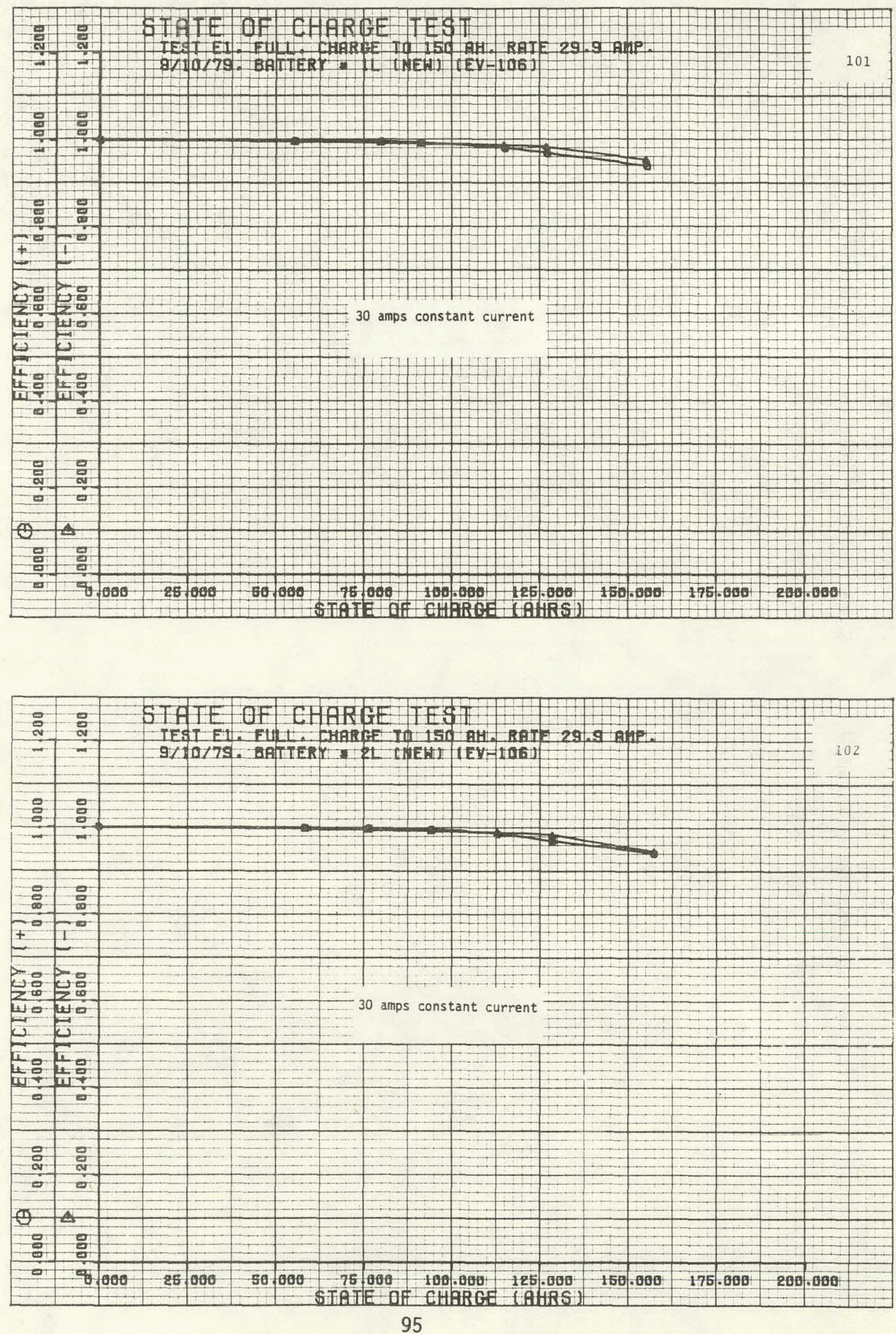

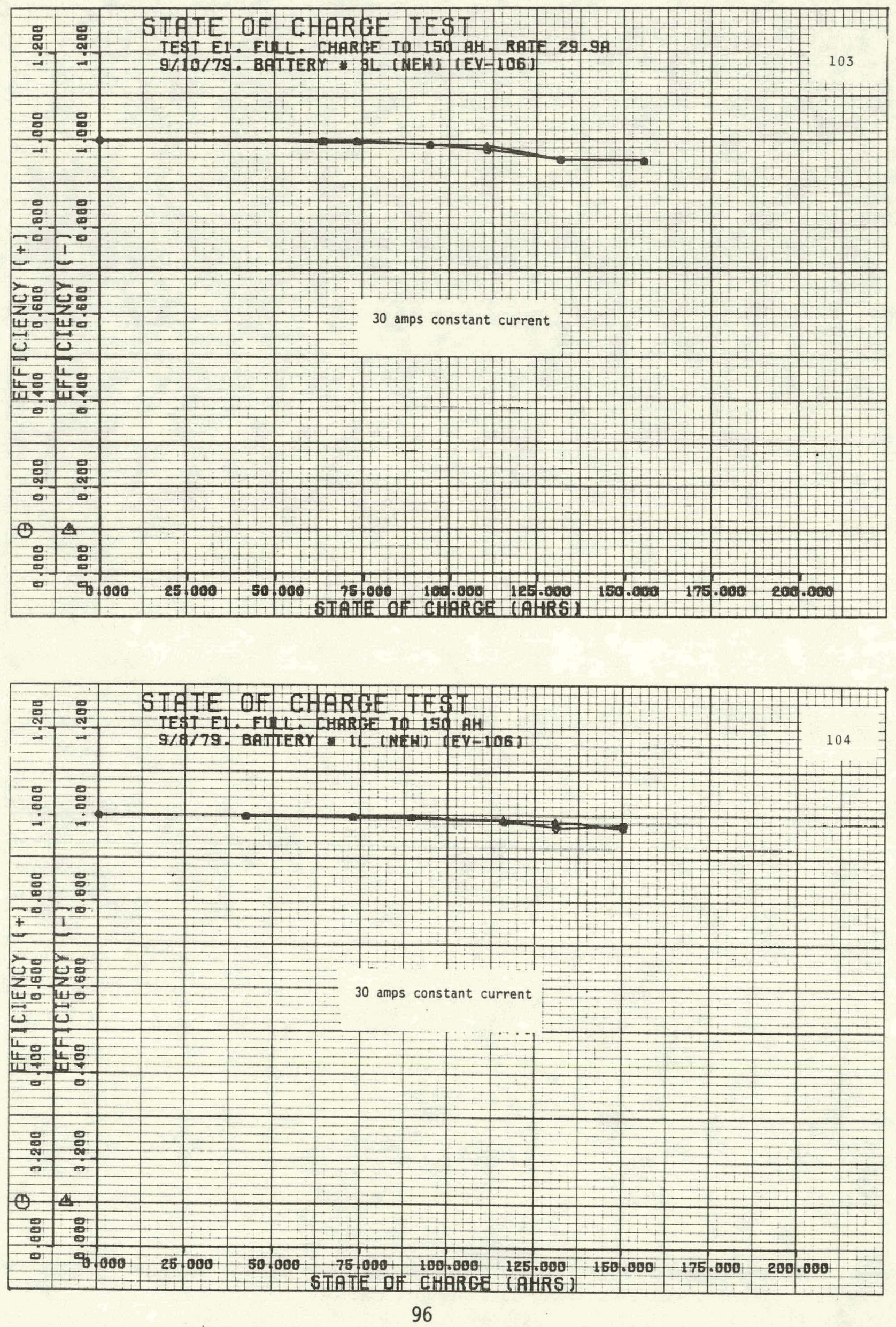

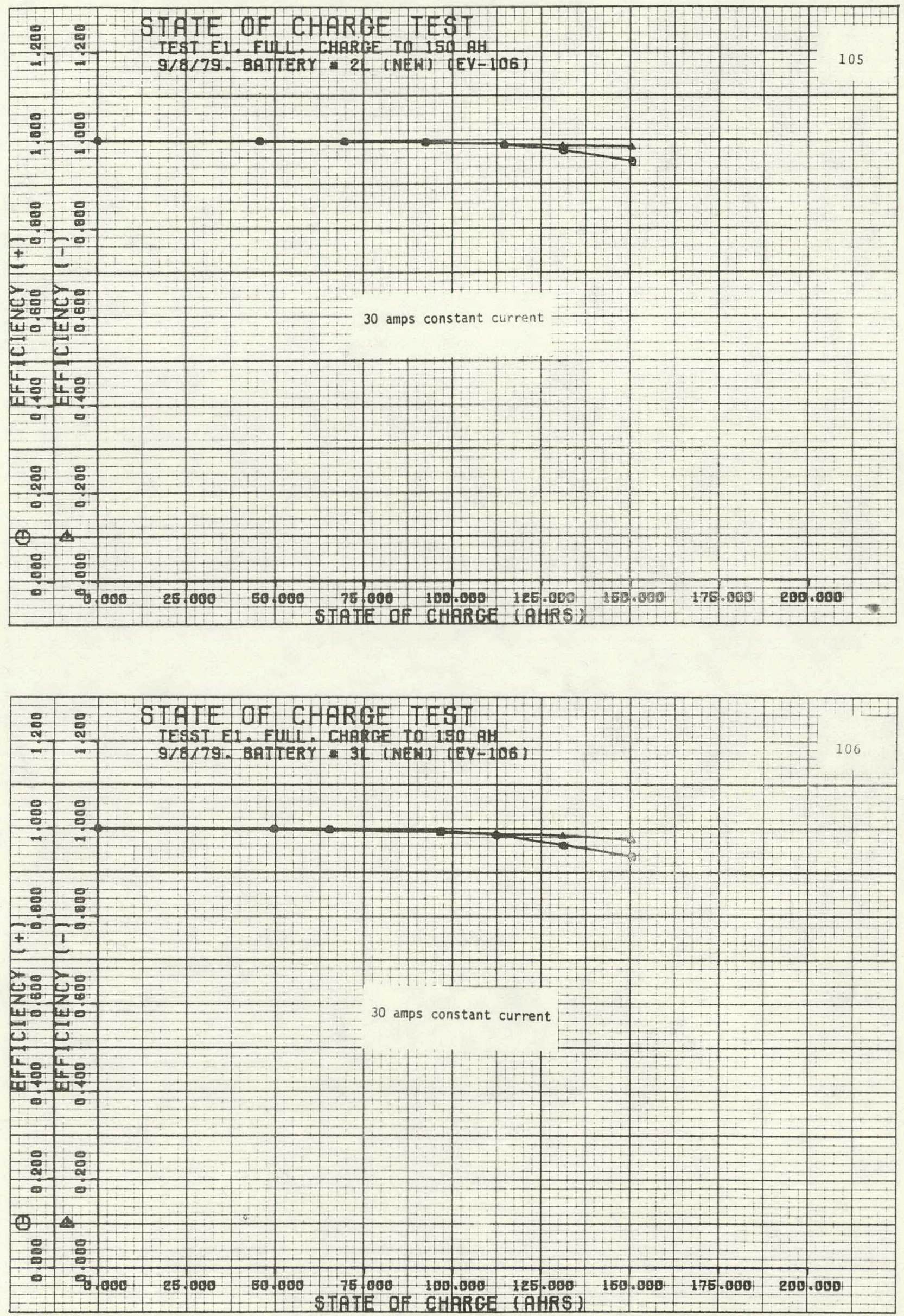

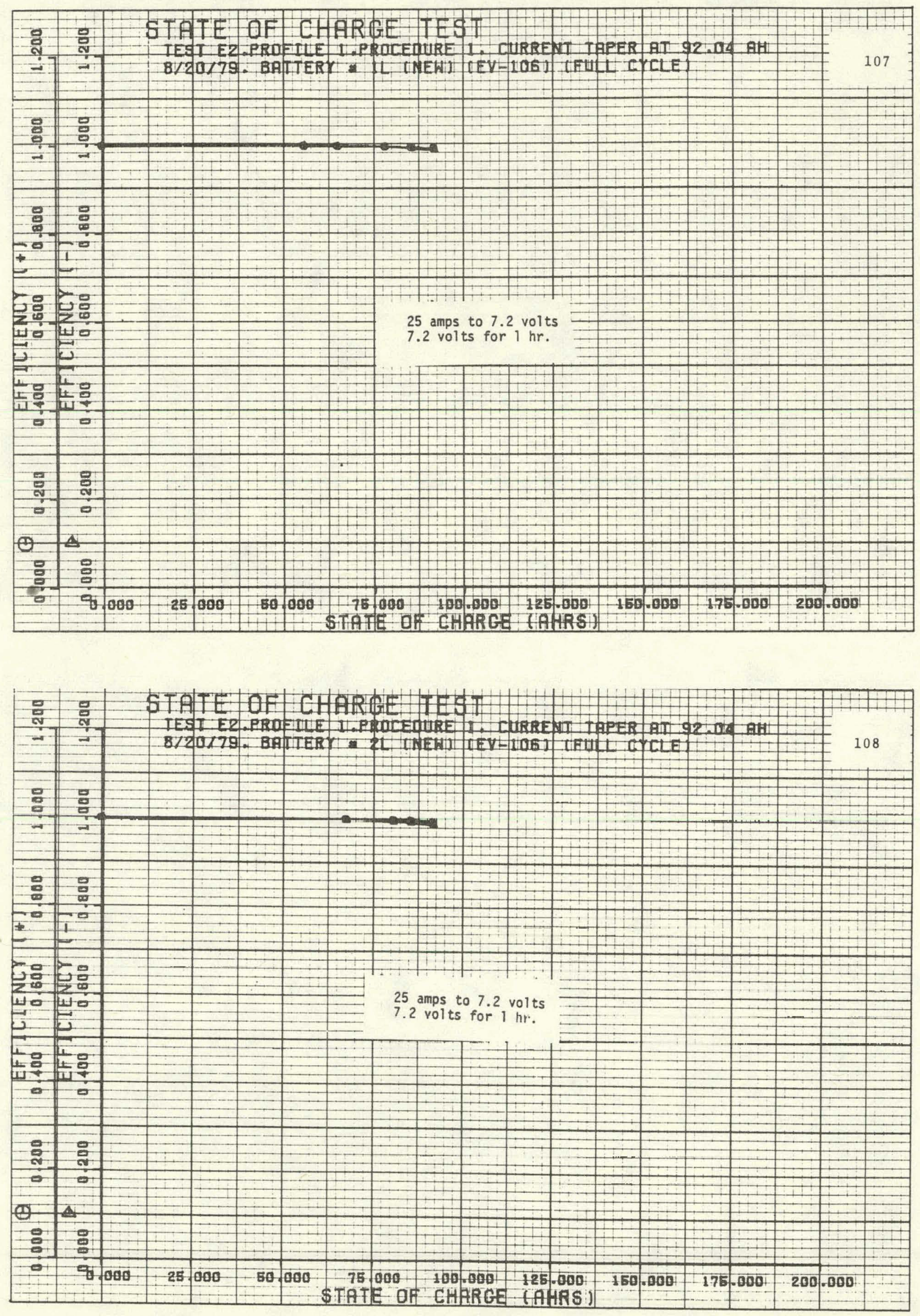

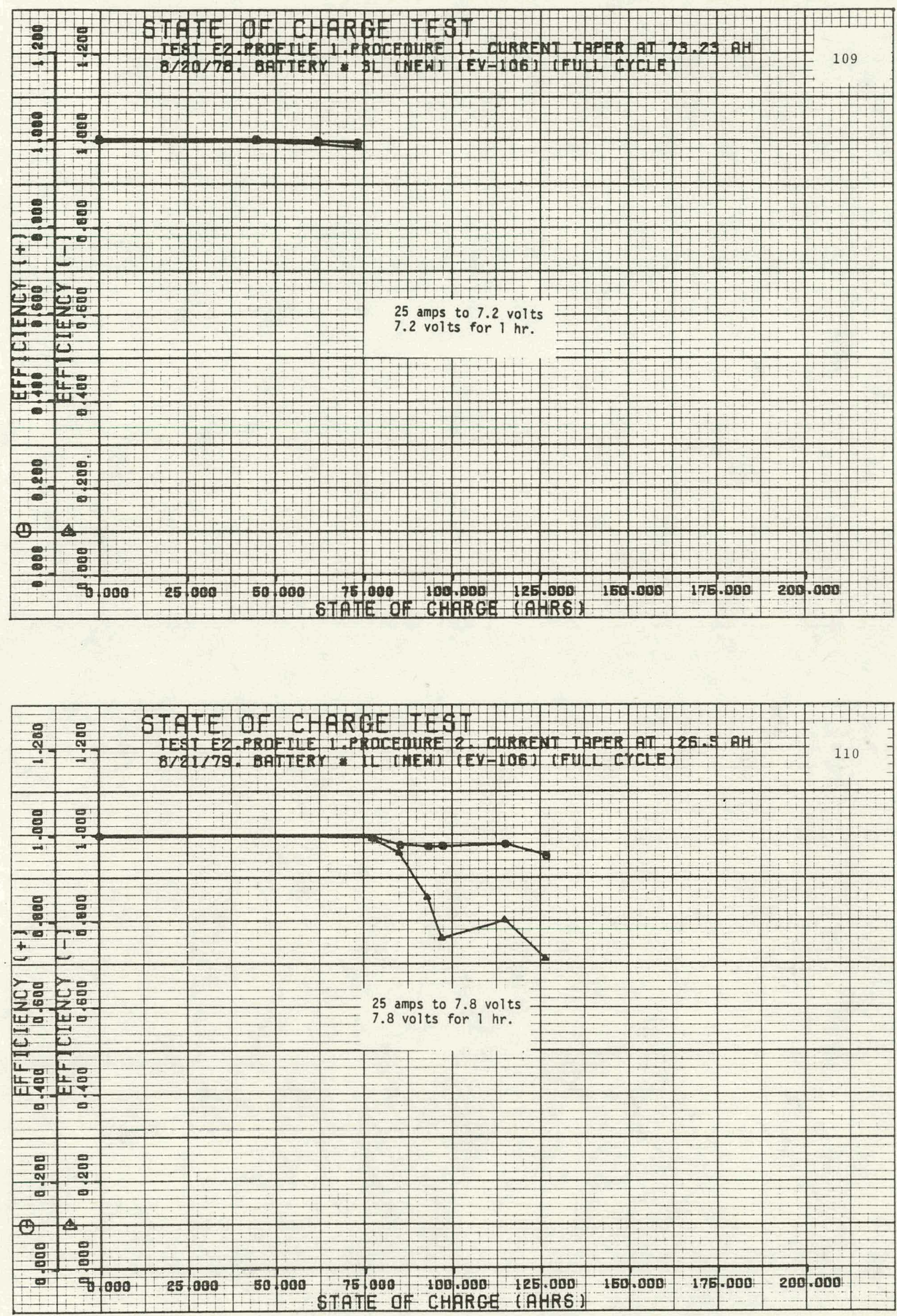

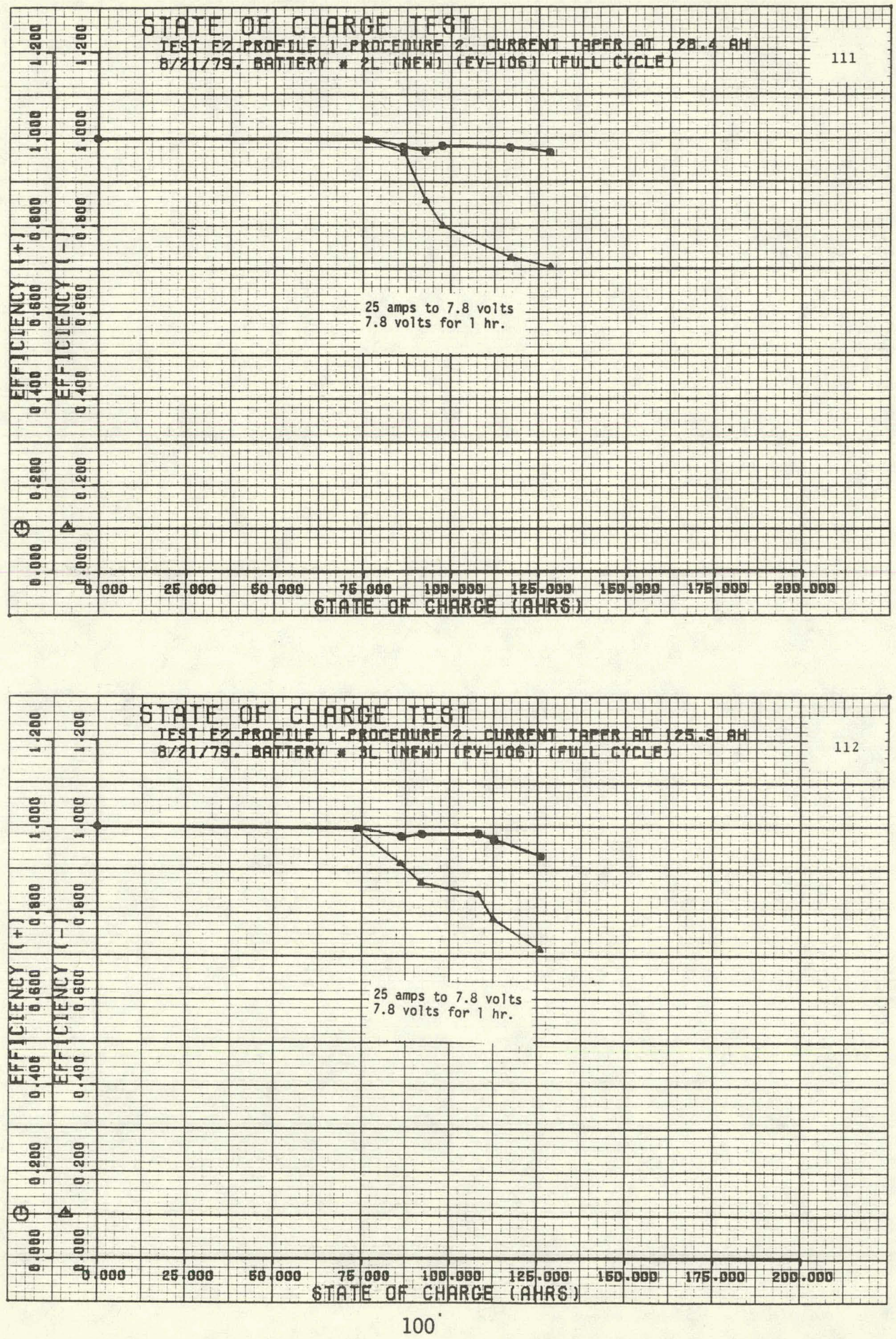

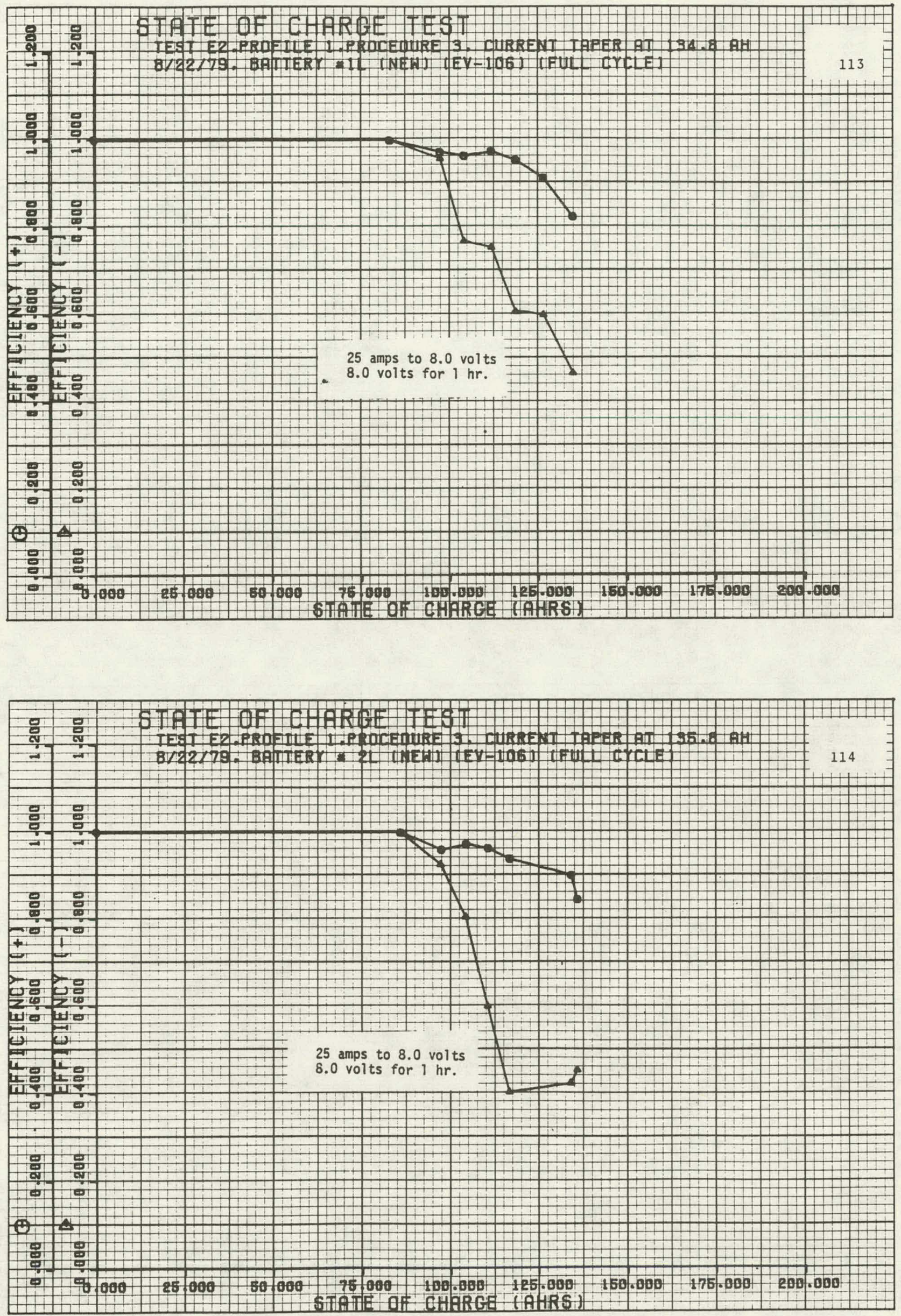

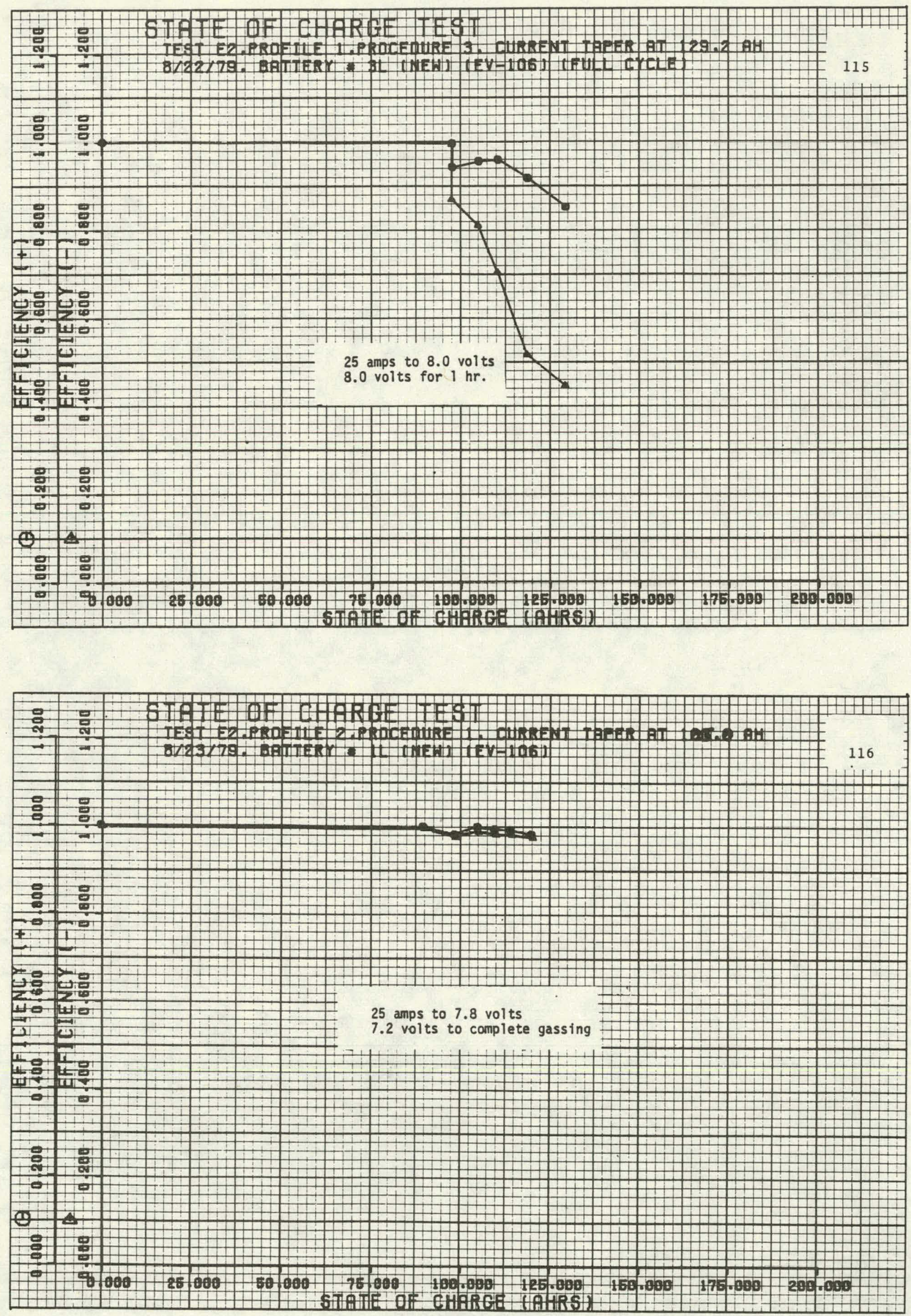

$10 ?$ 

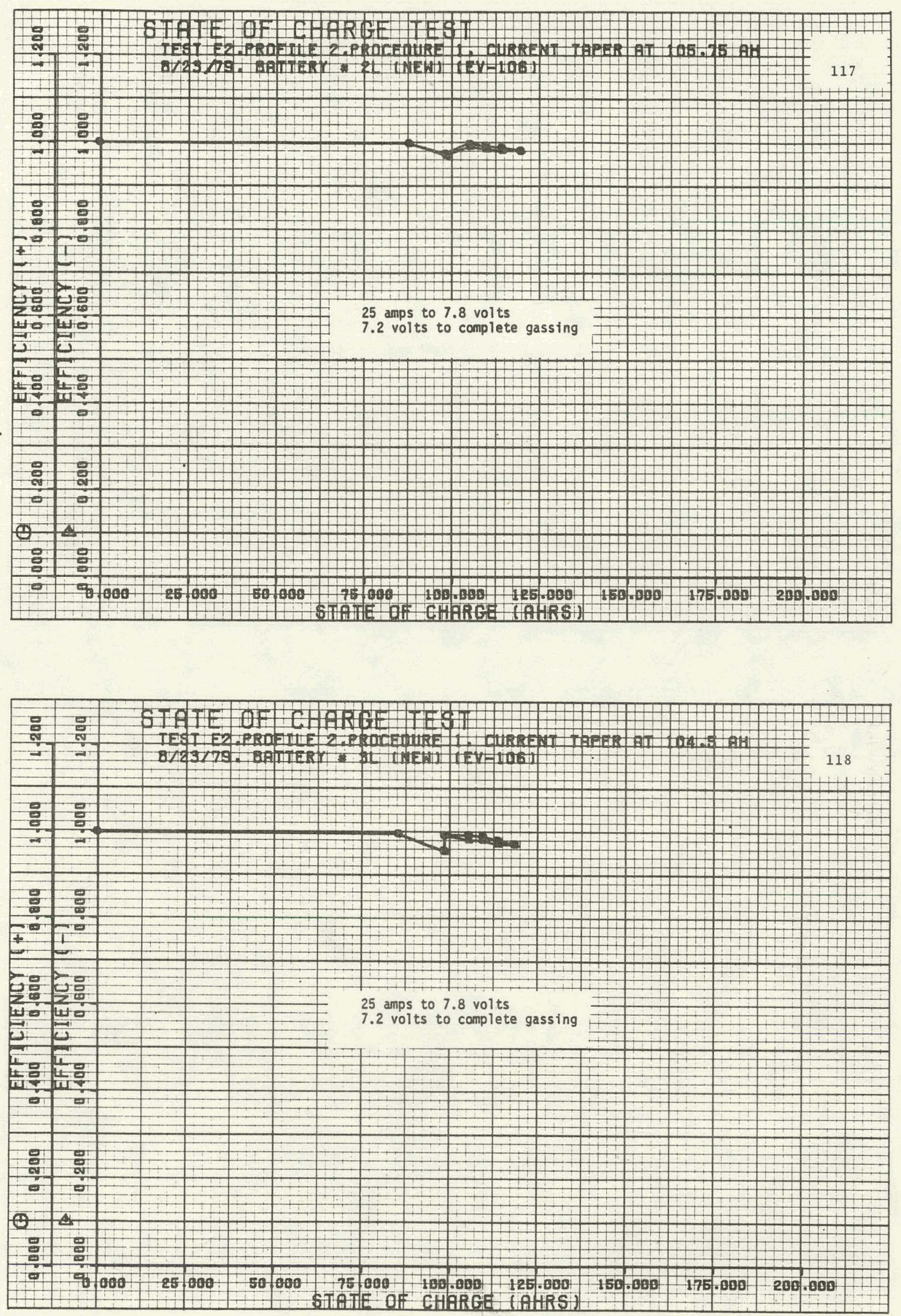

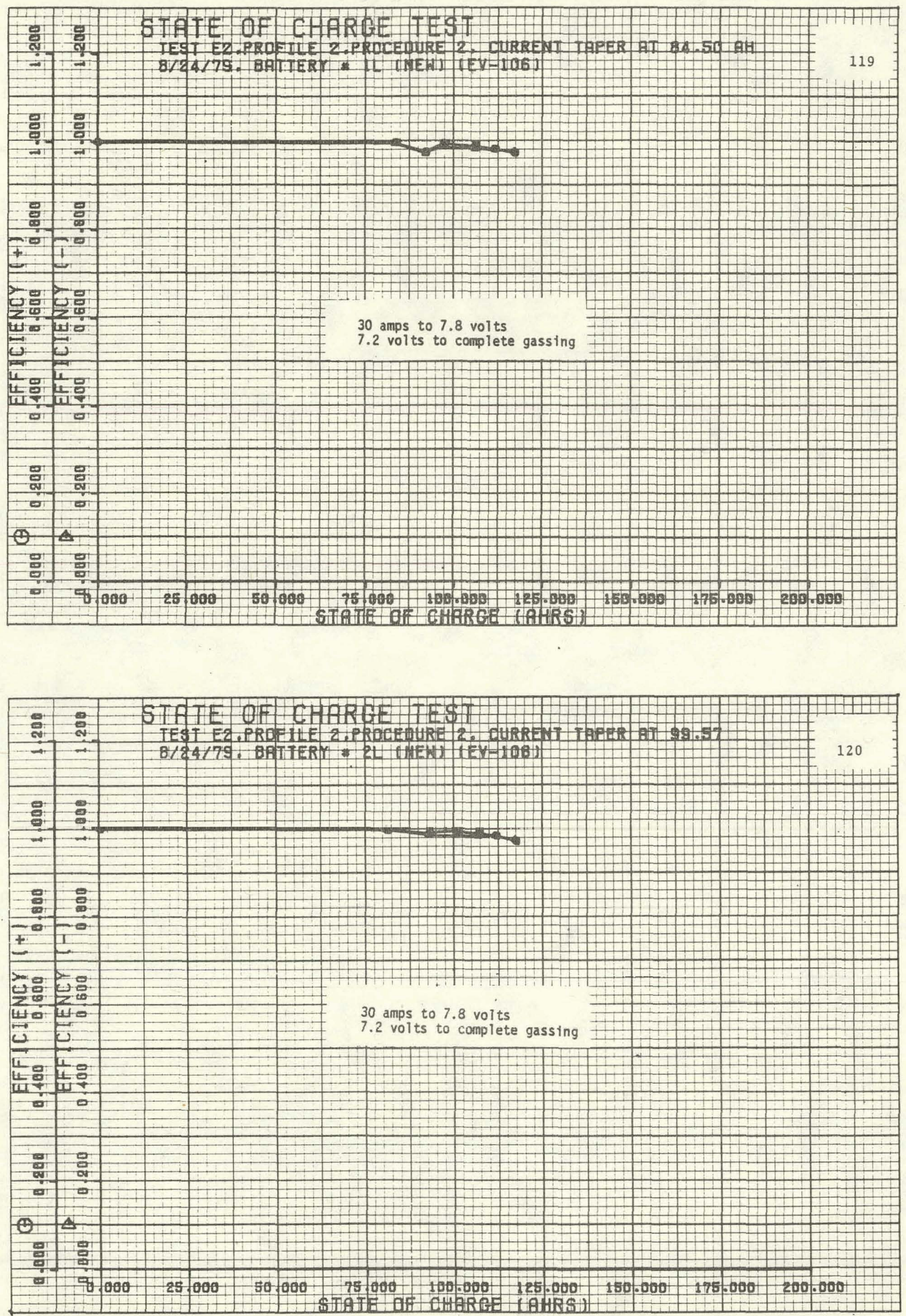

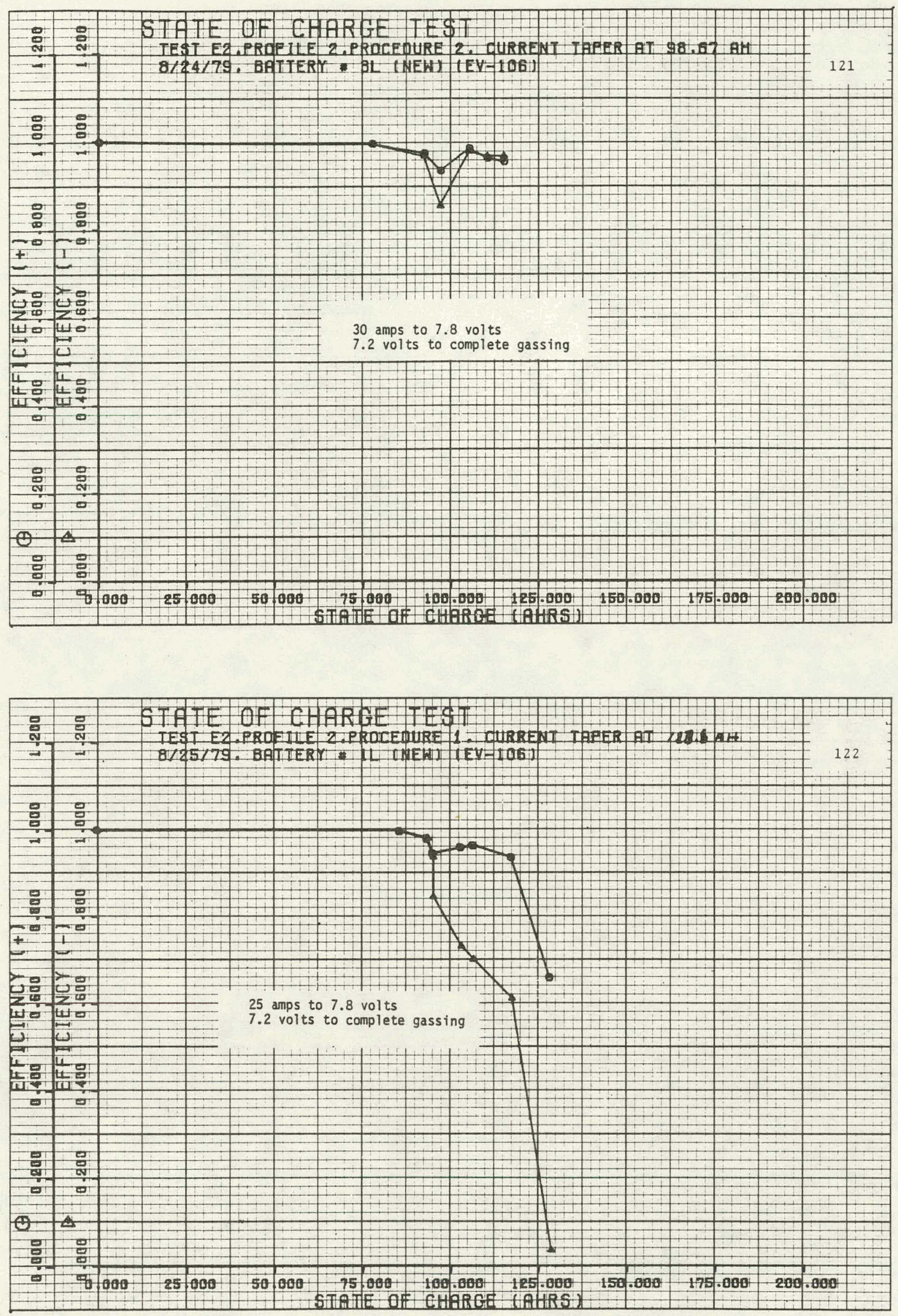

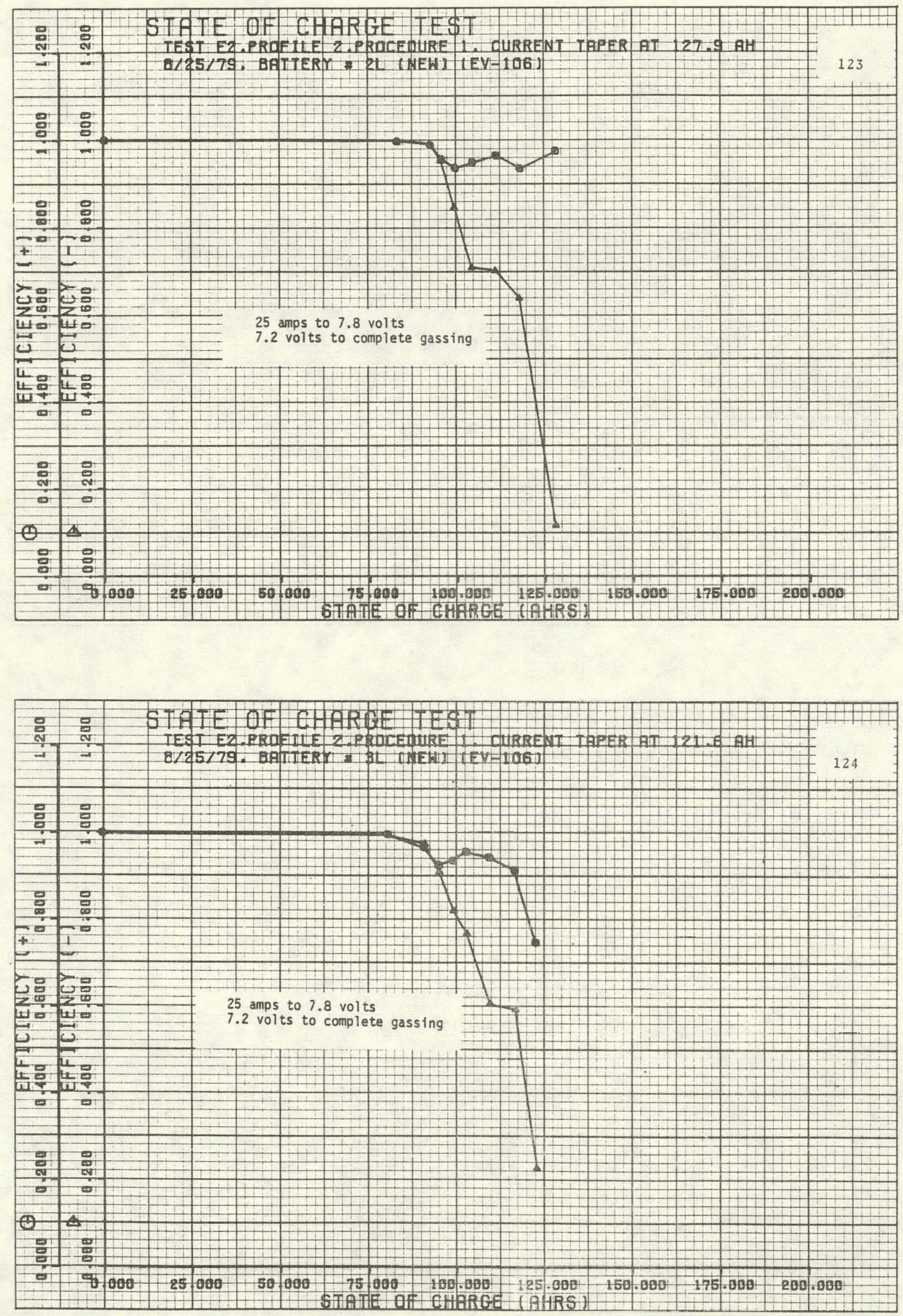
APPENDIX B

AGE CYCLING OF ESB EV-106 LEAD-ACID BATTERIES 


\section{THIS PAGE WAS INTENTIONALLY LEFT BLANK}



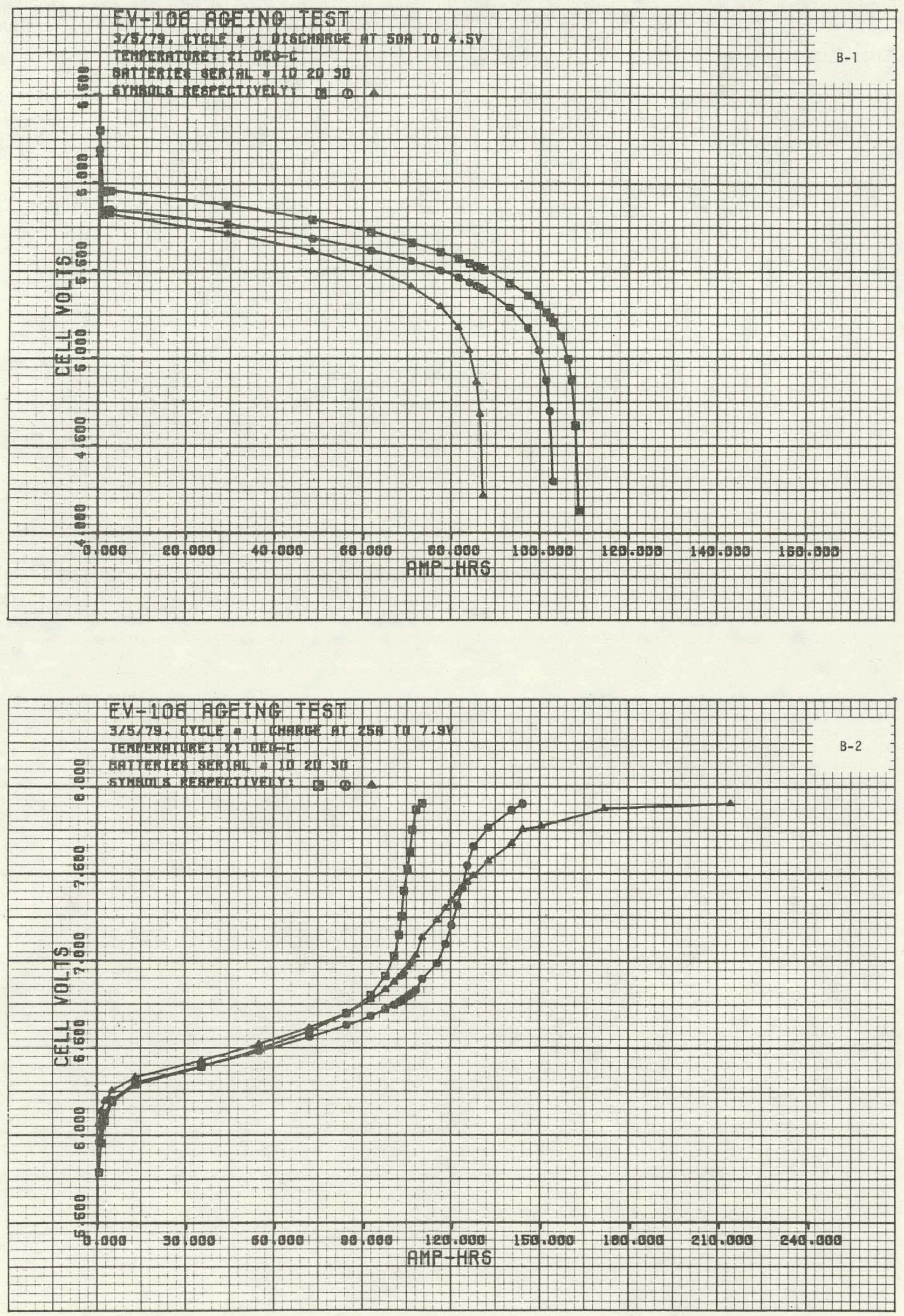

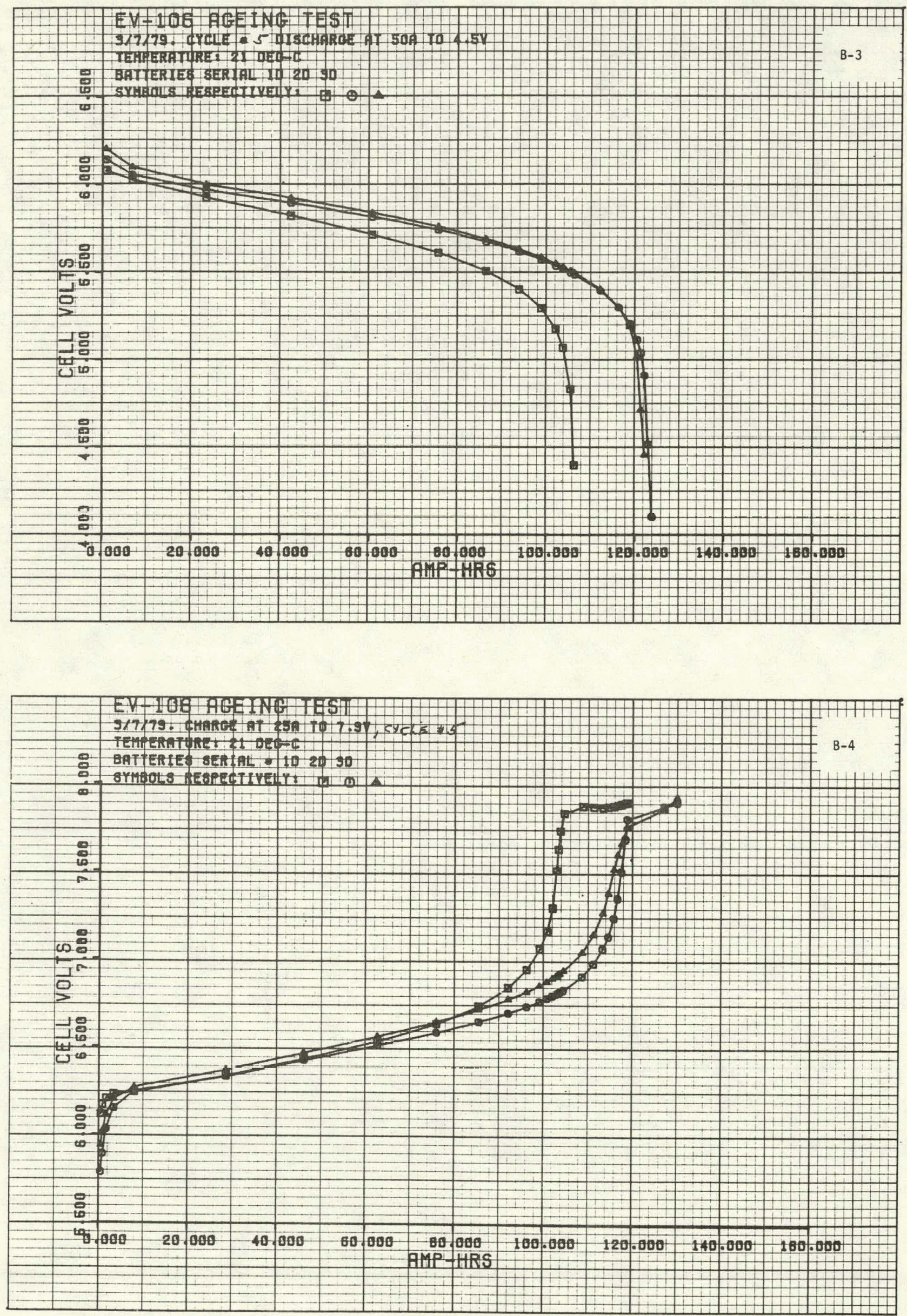

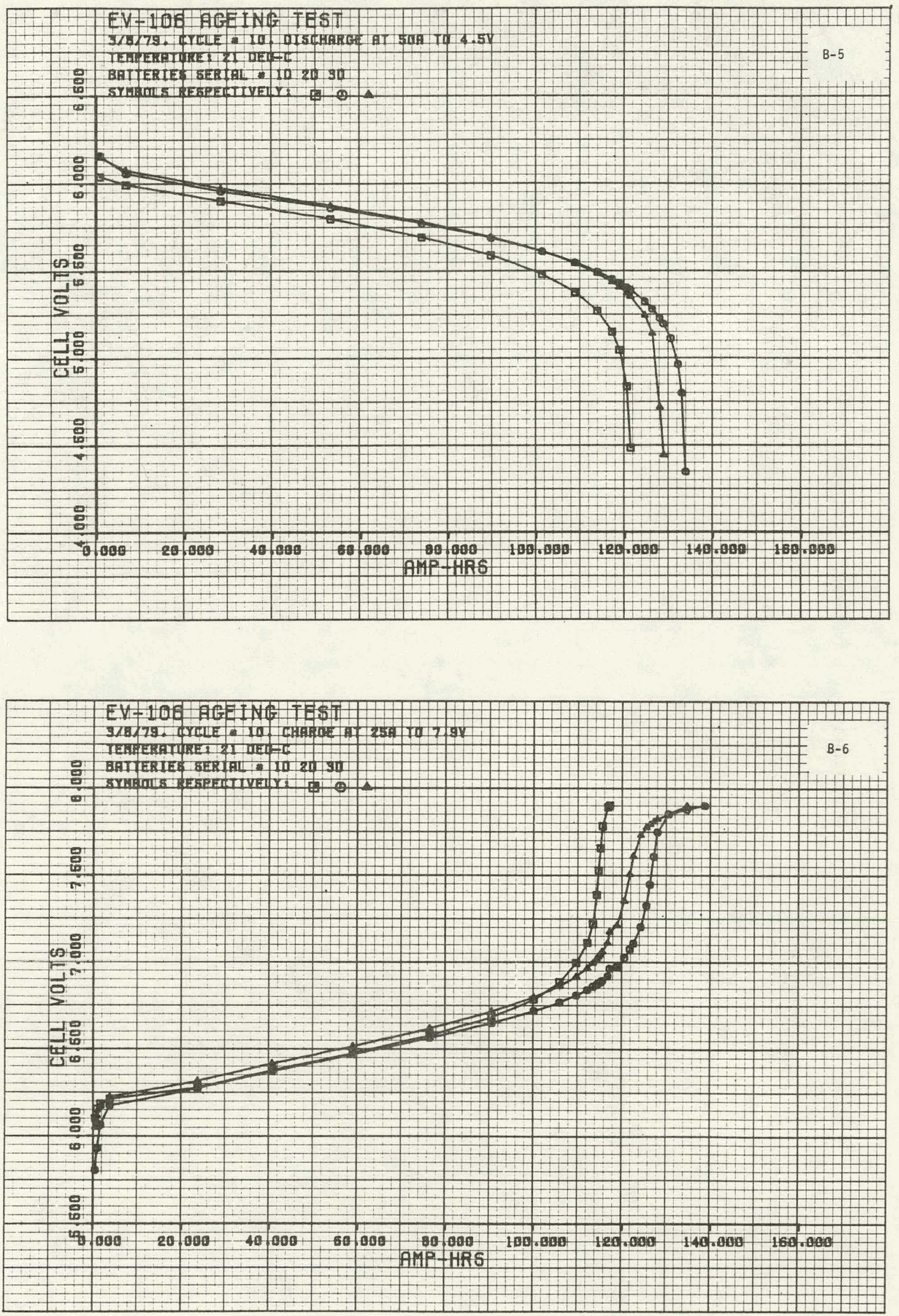

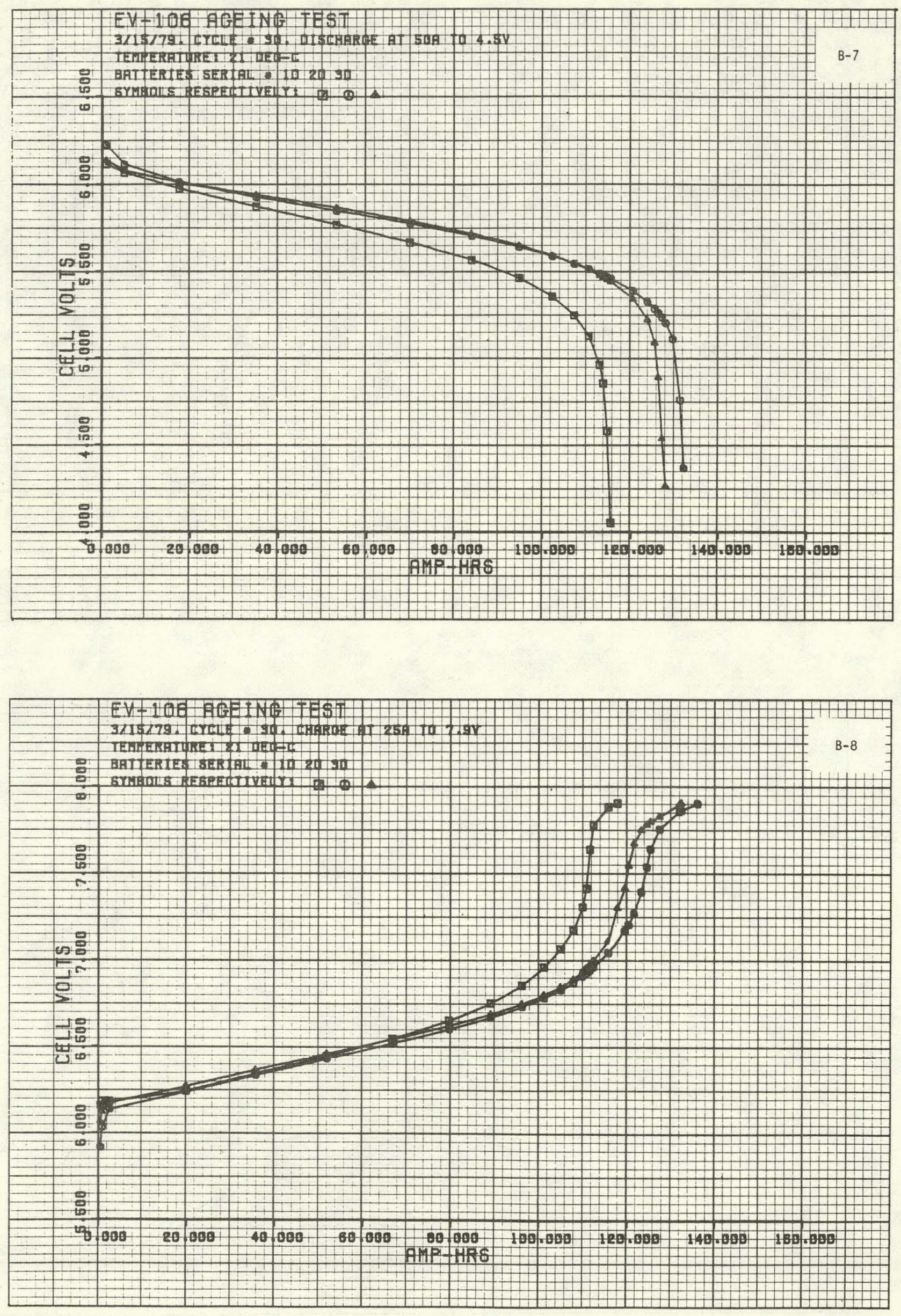

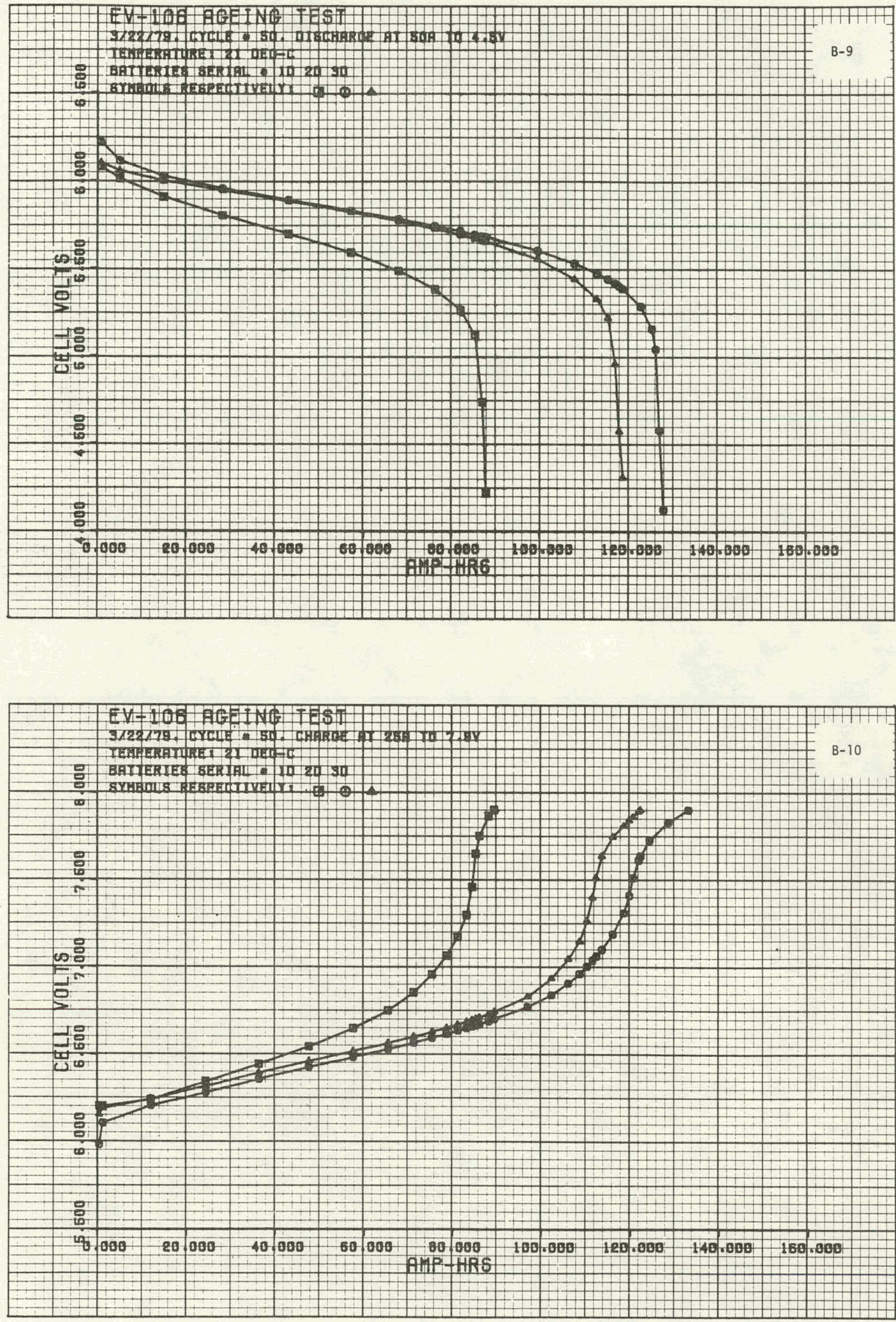

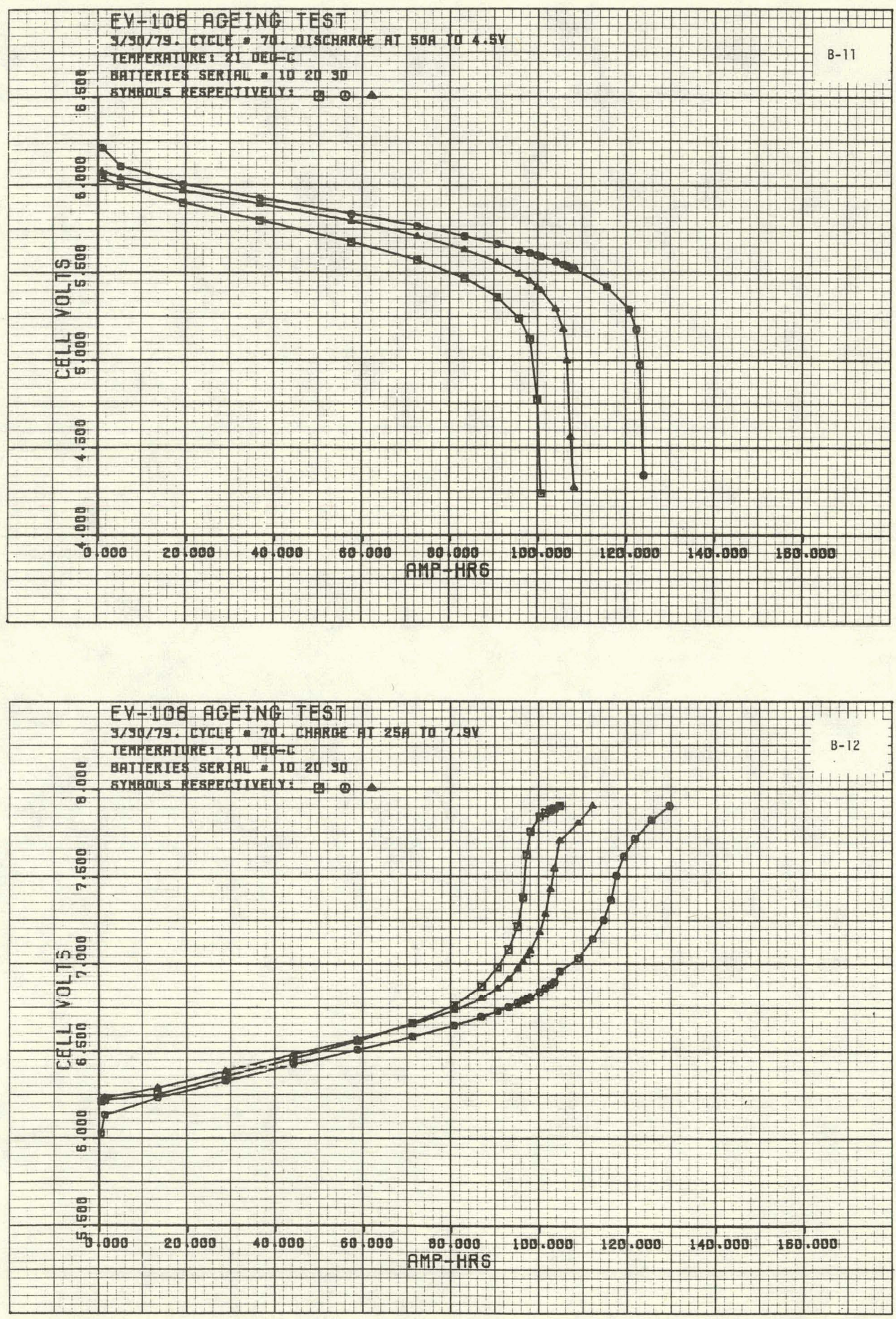

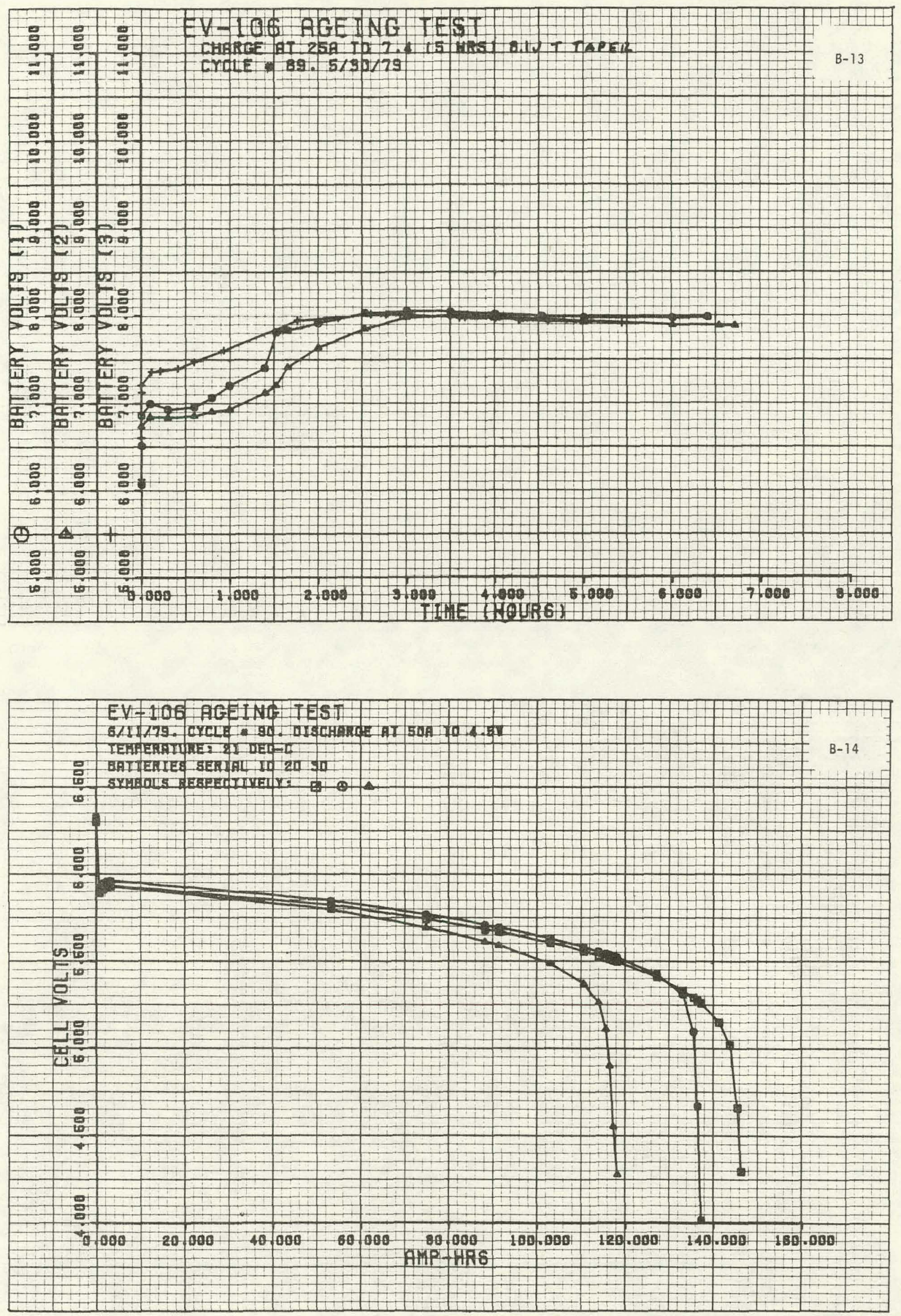

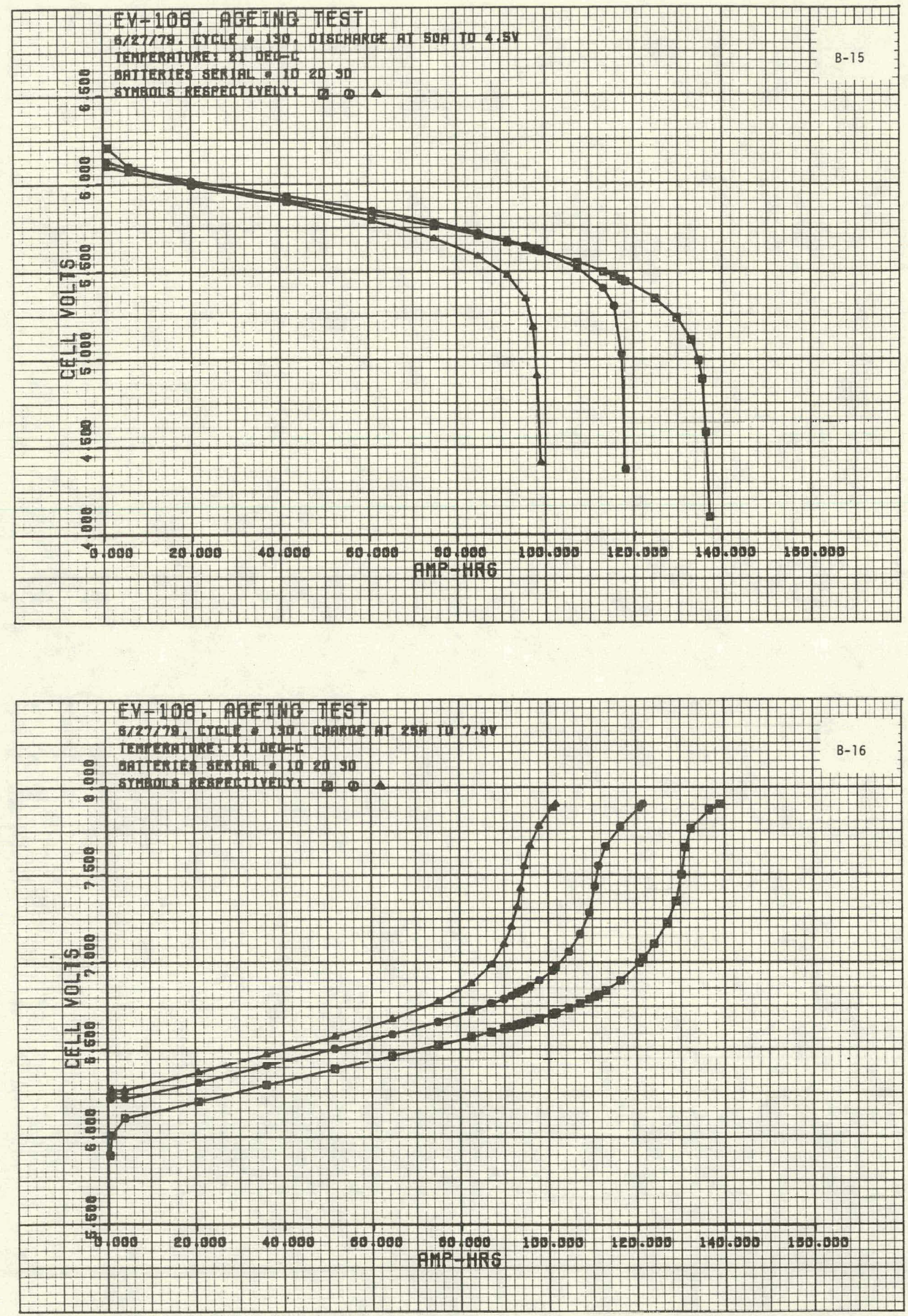

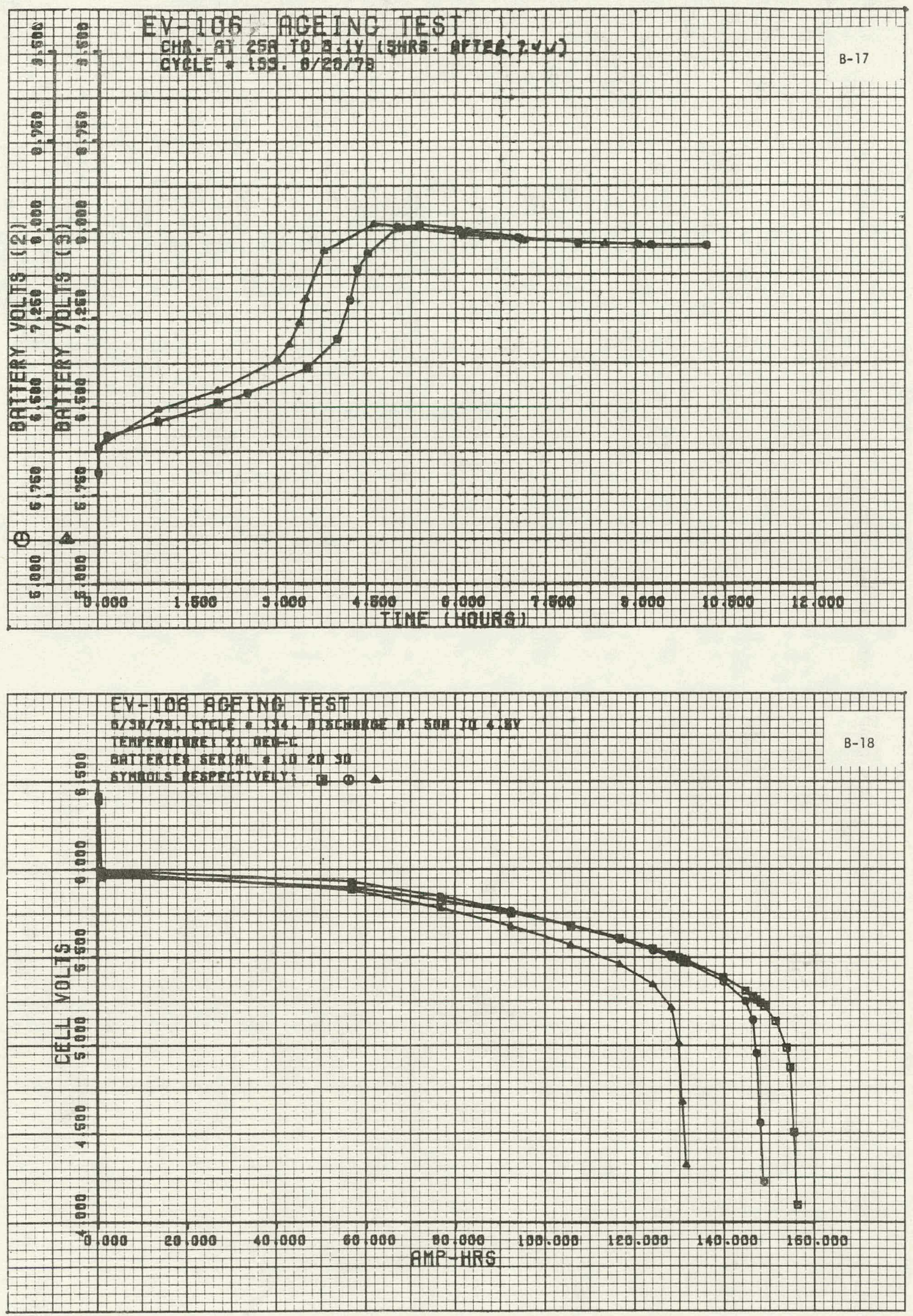

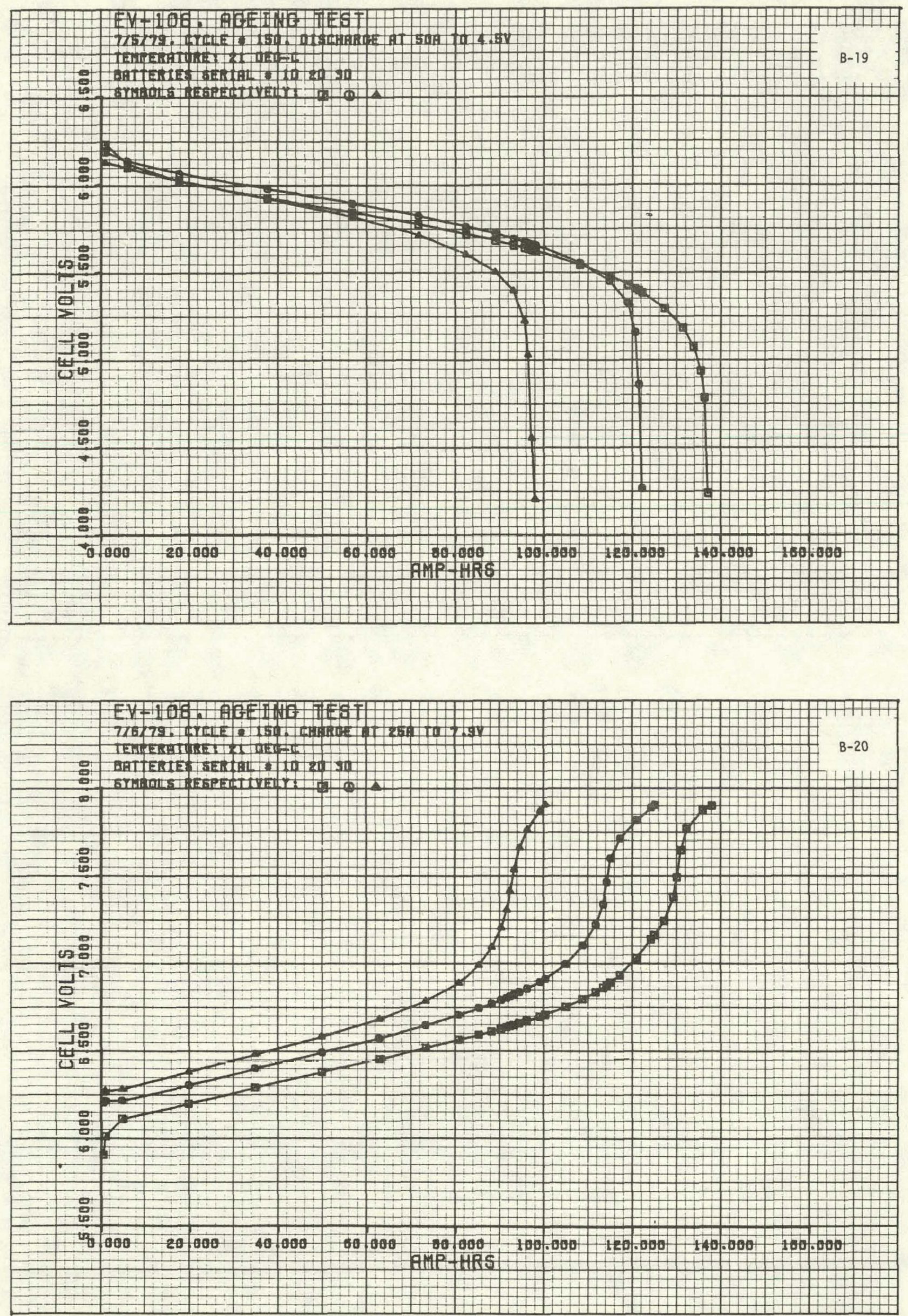

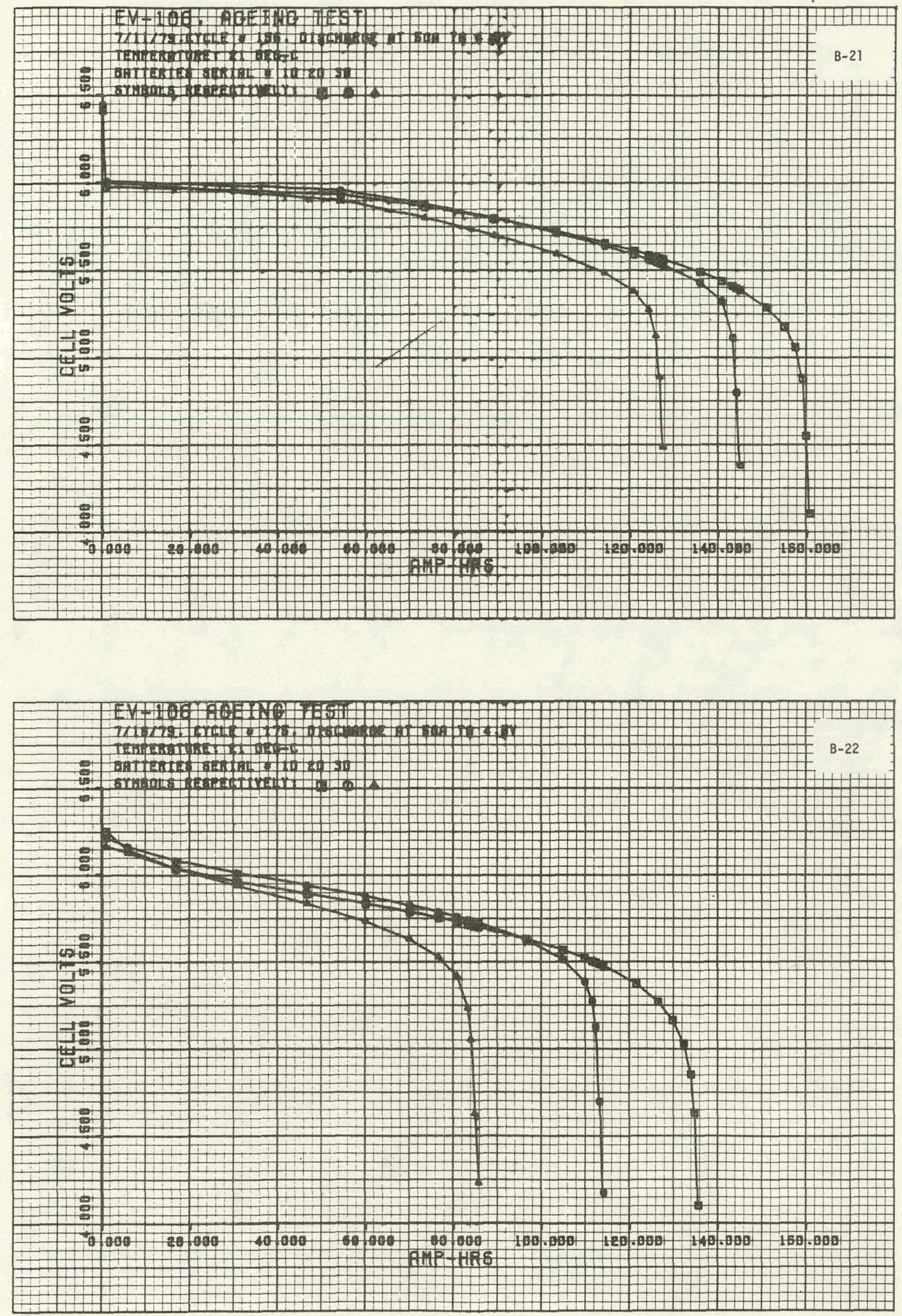

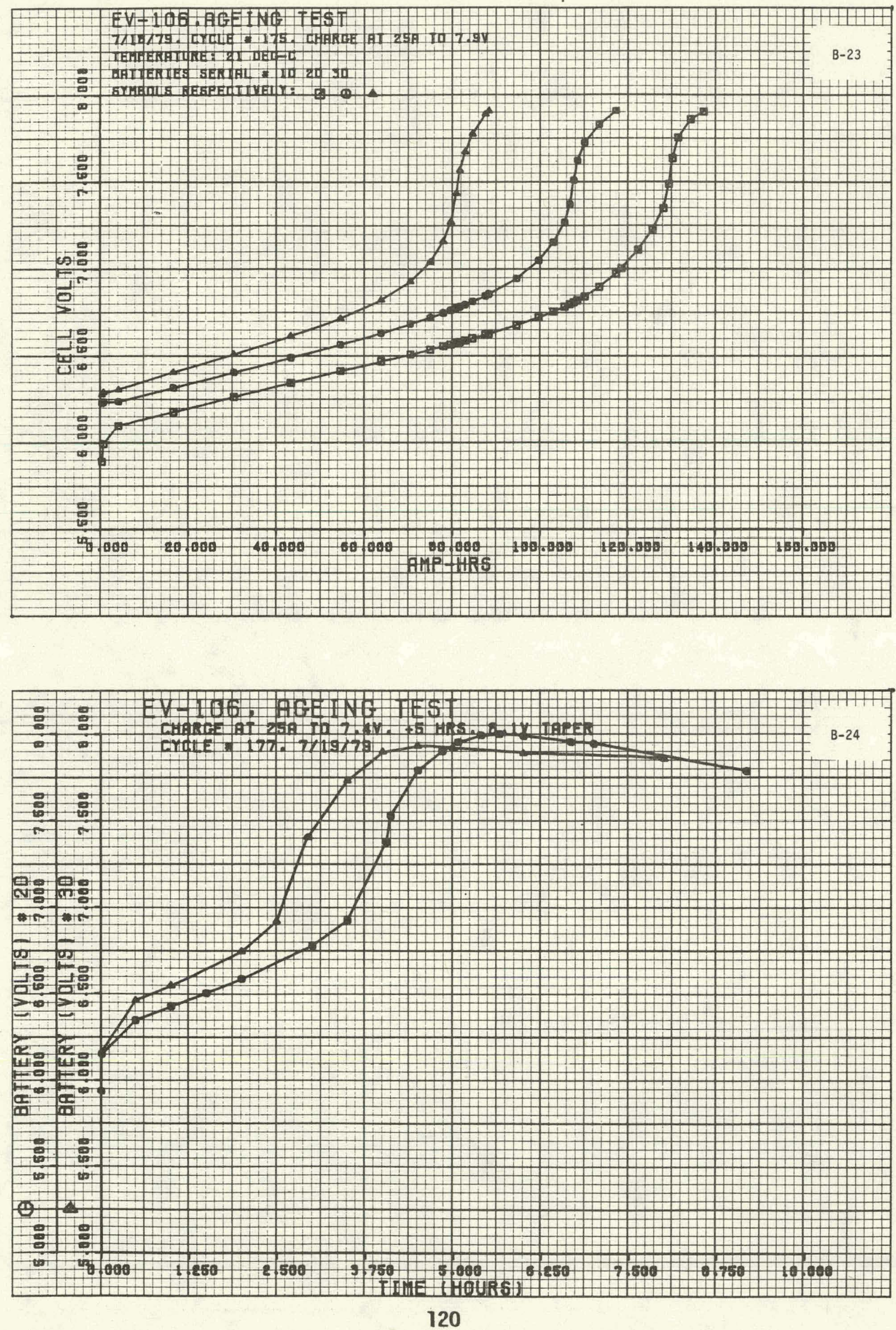

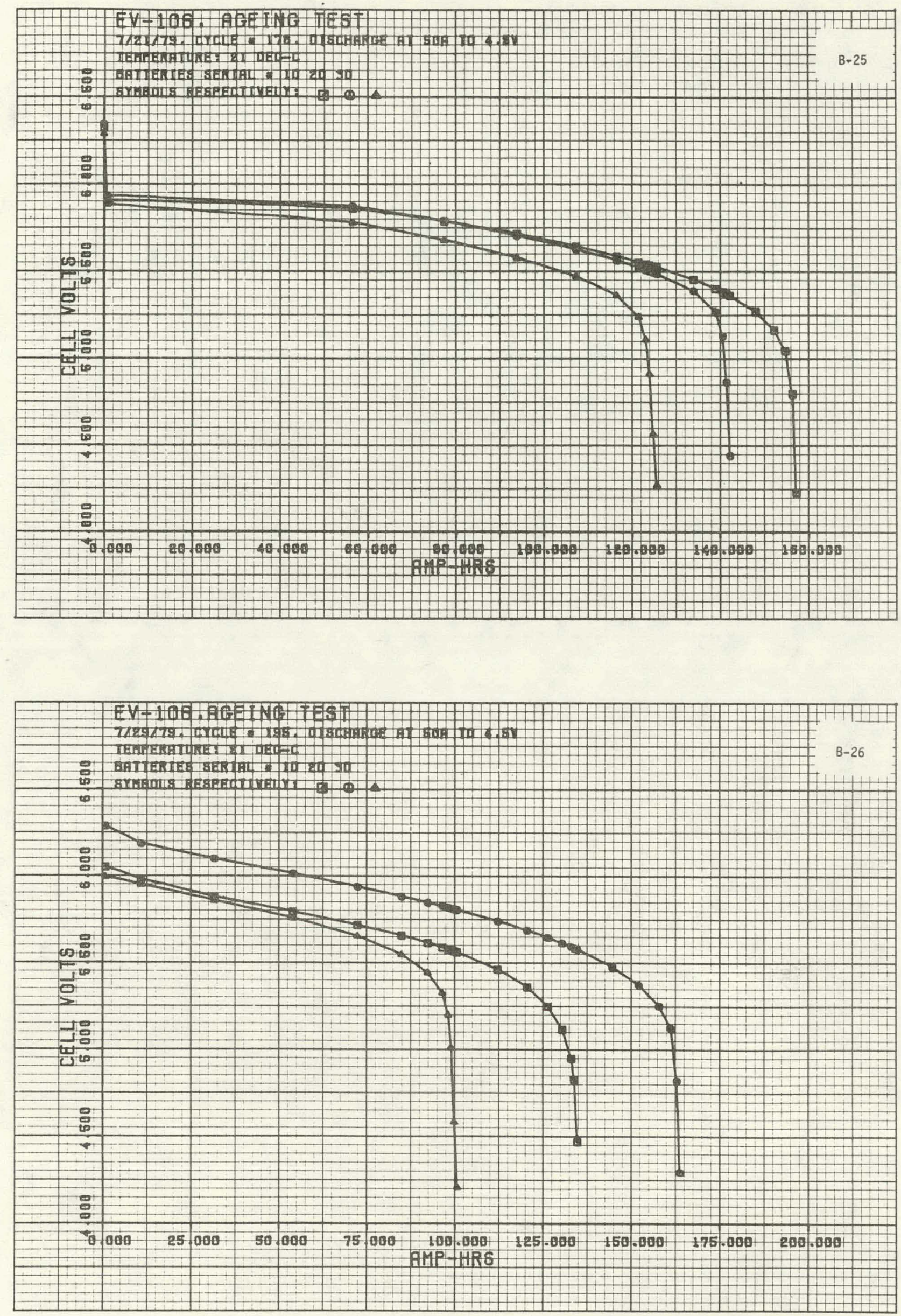


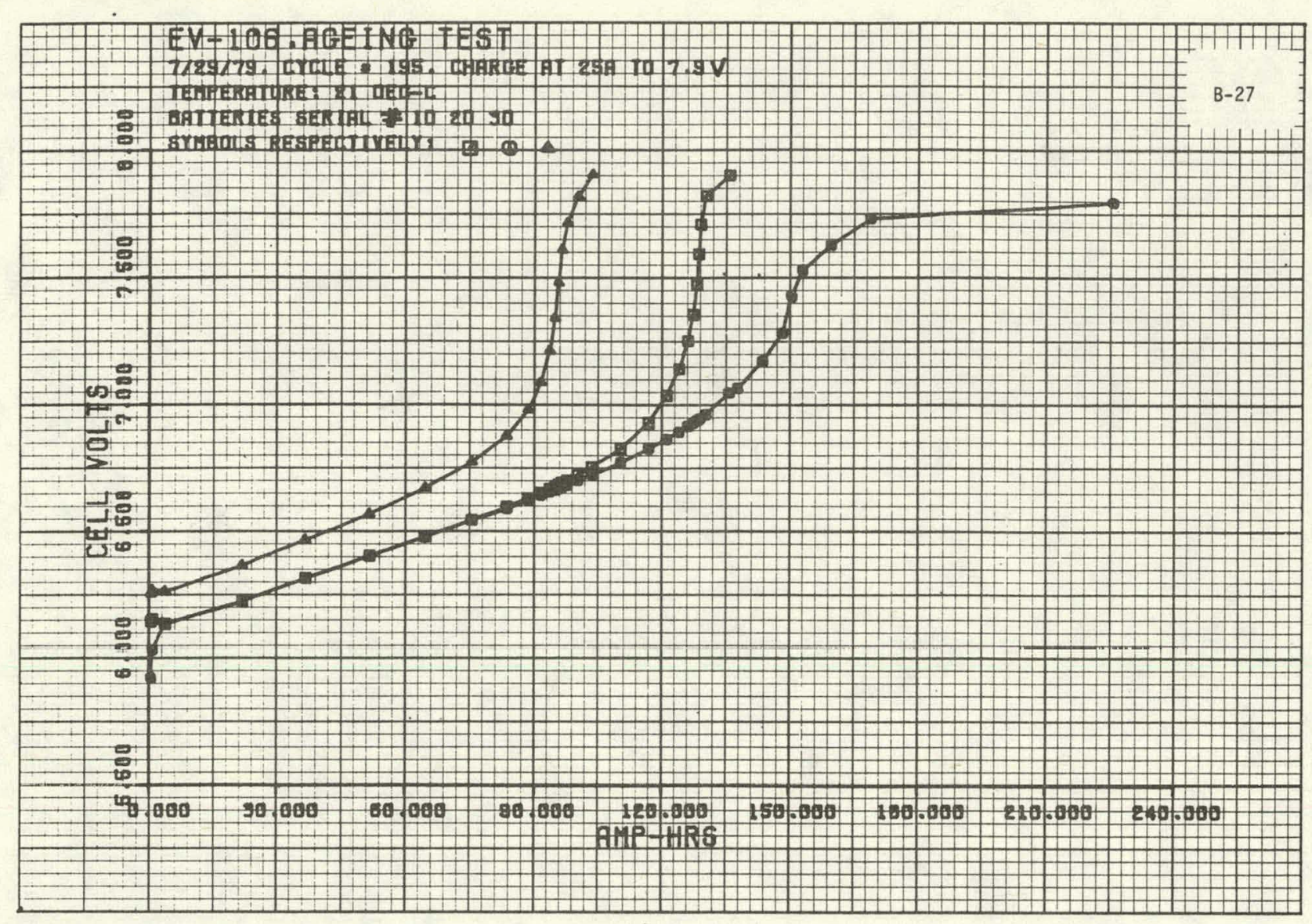




\section{APPENDIX C}

ENERGY EFFICIENCY TESTS OF ESB EV-106 LEAD-ACID BATTERIES 


\section{THIS PAGE WAS INTENTIONALLY LEFT BLANK}



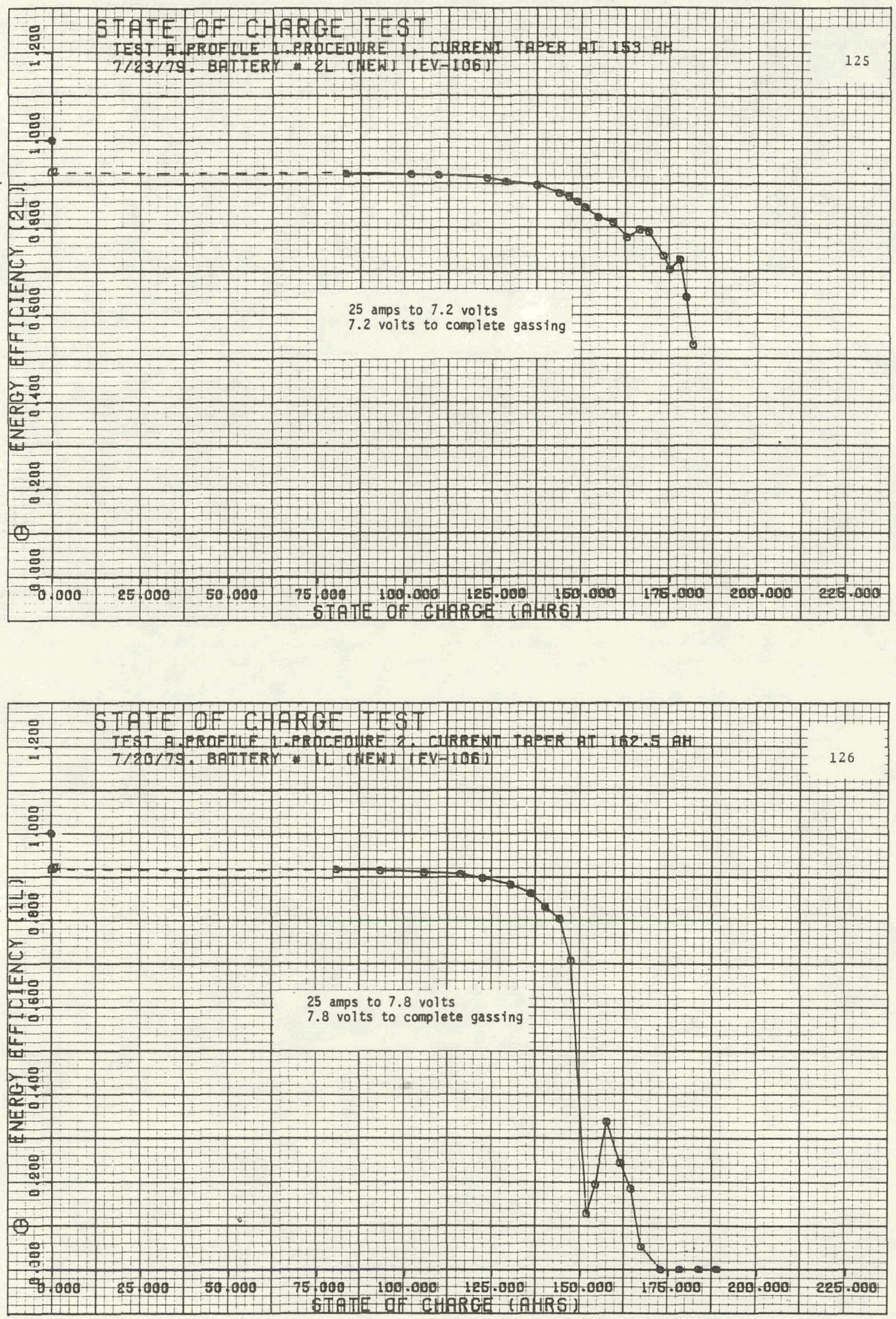

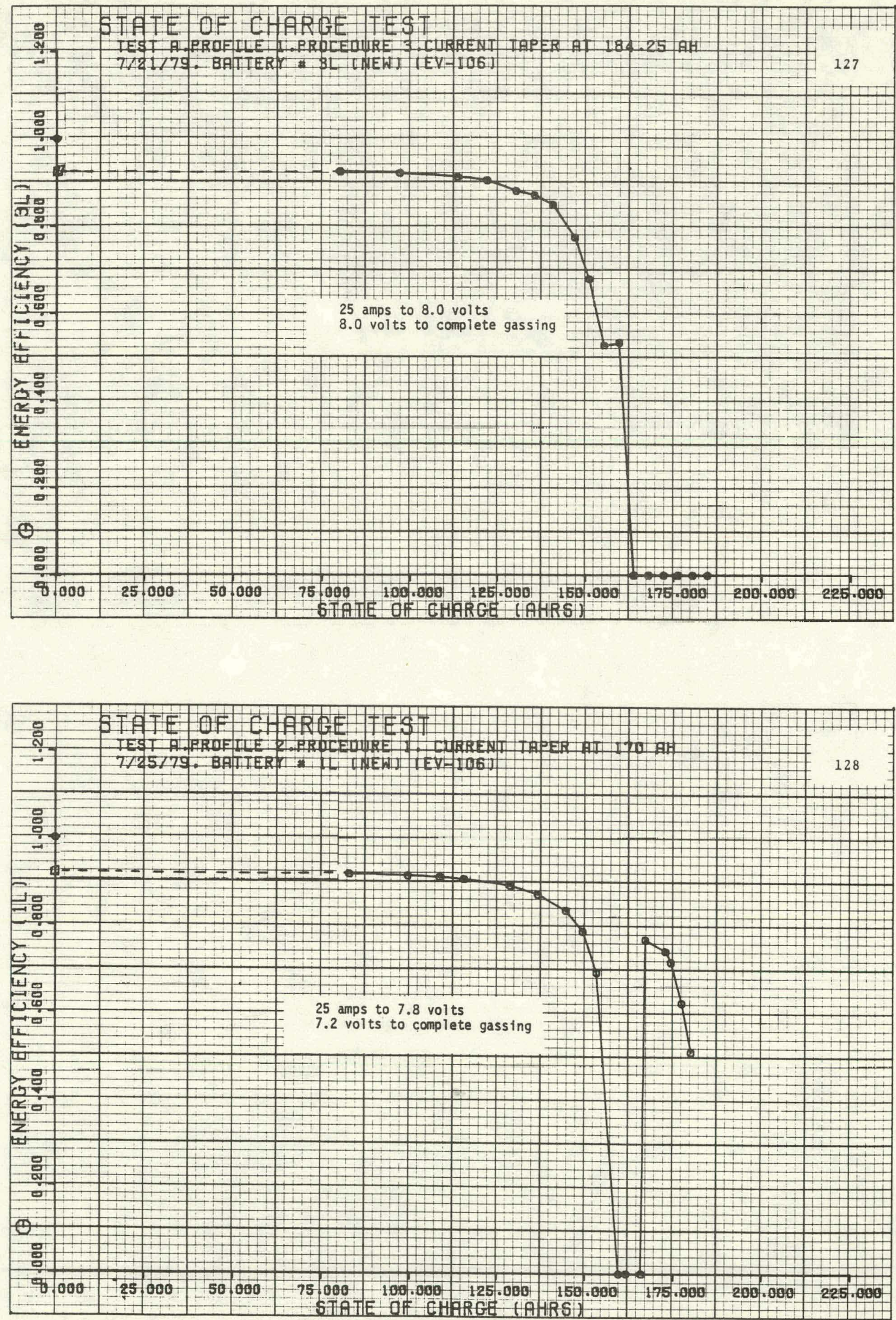

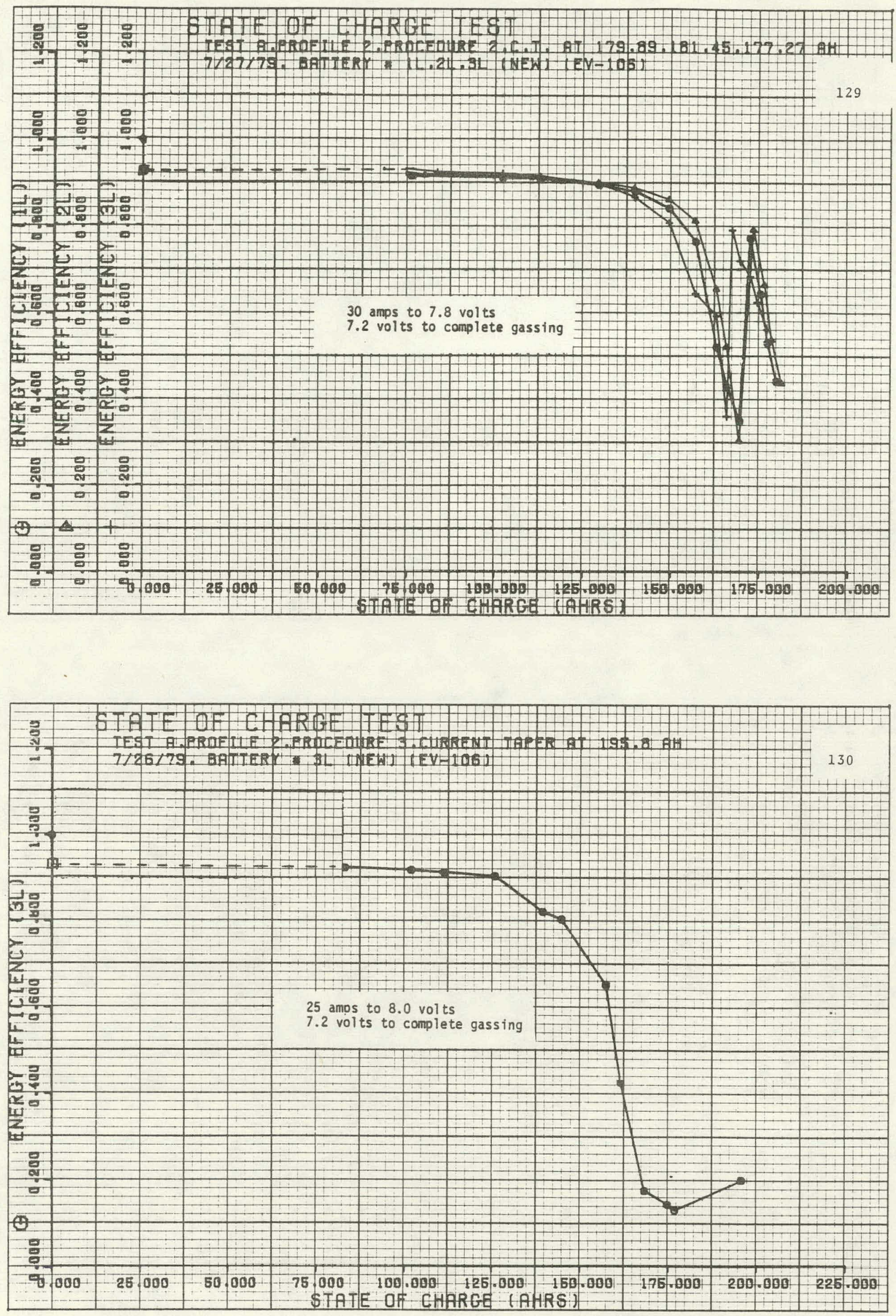

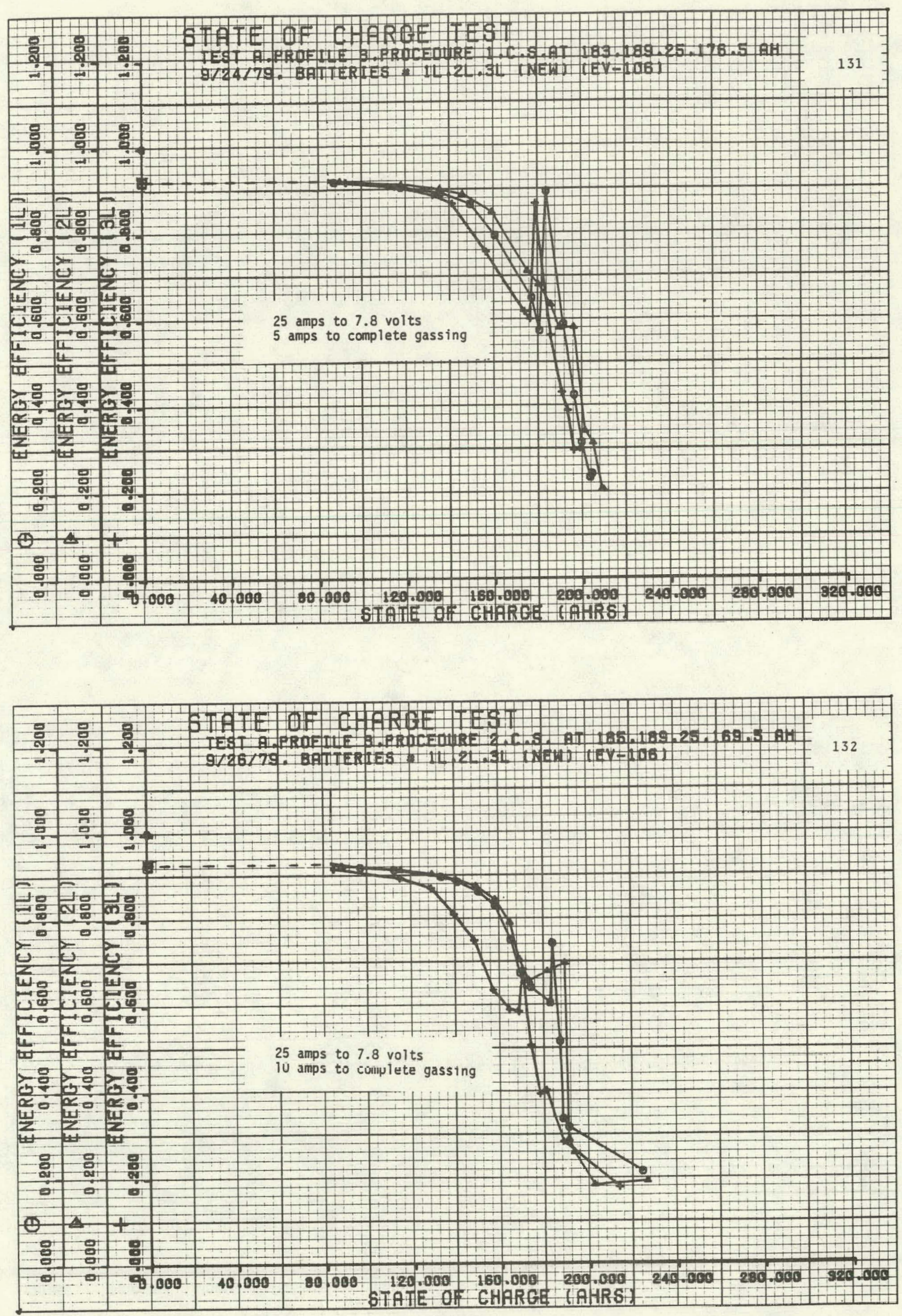

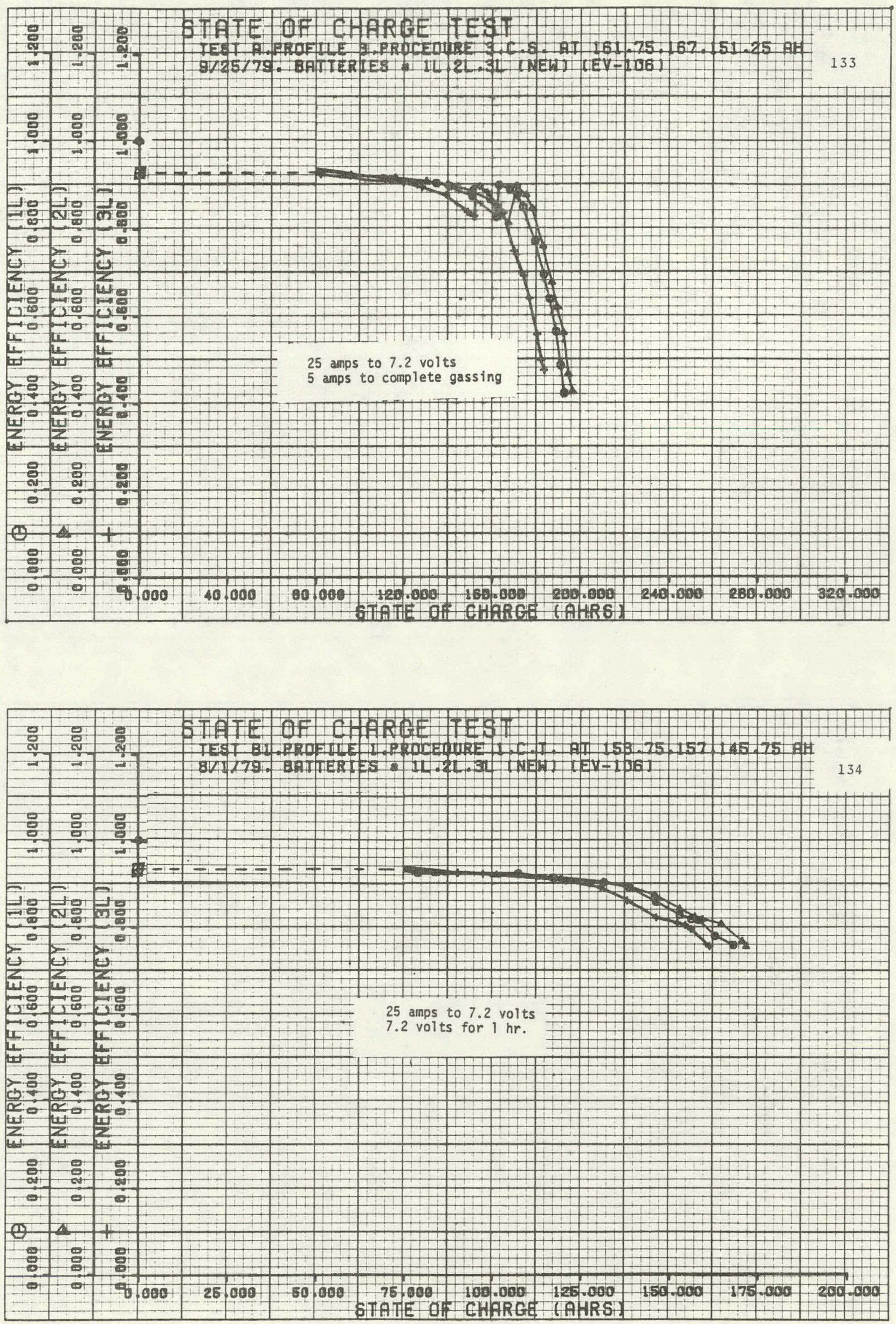

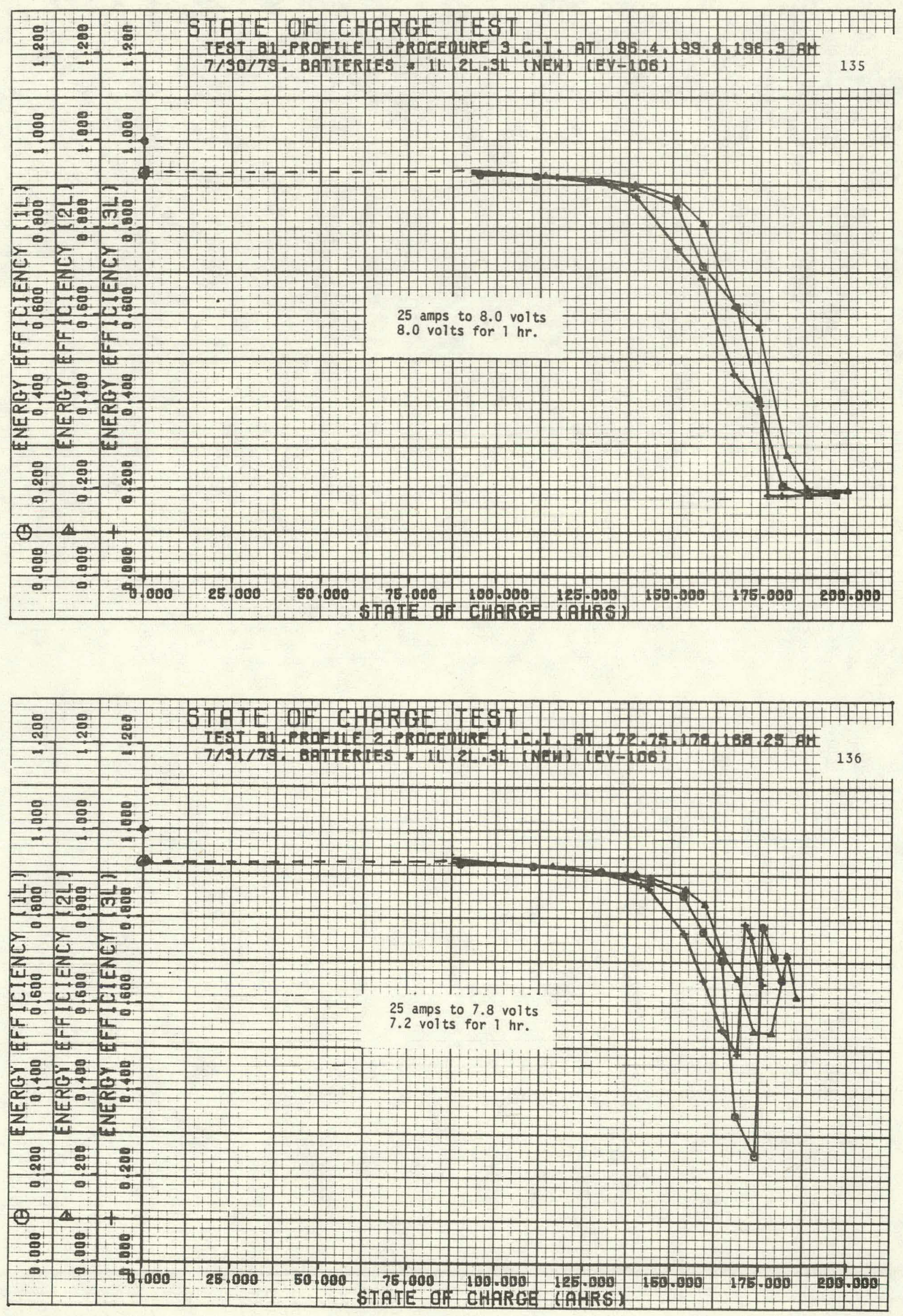

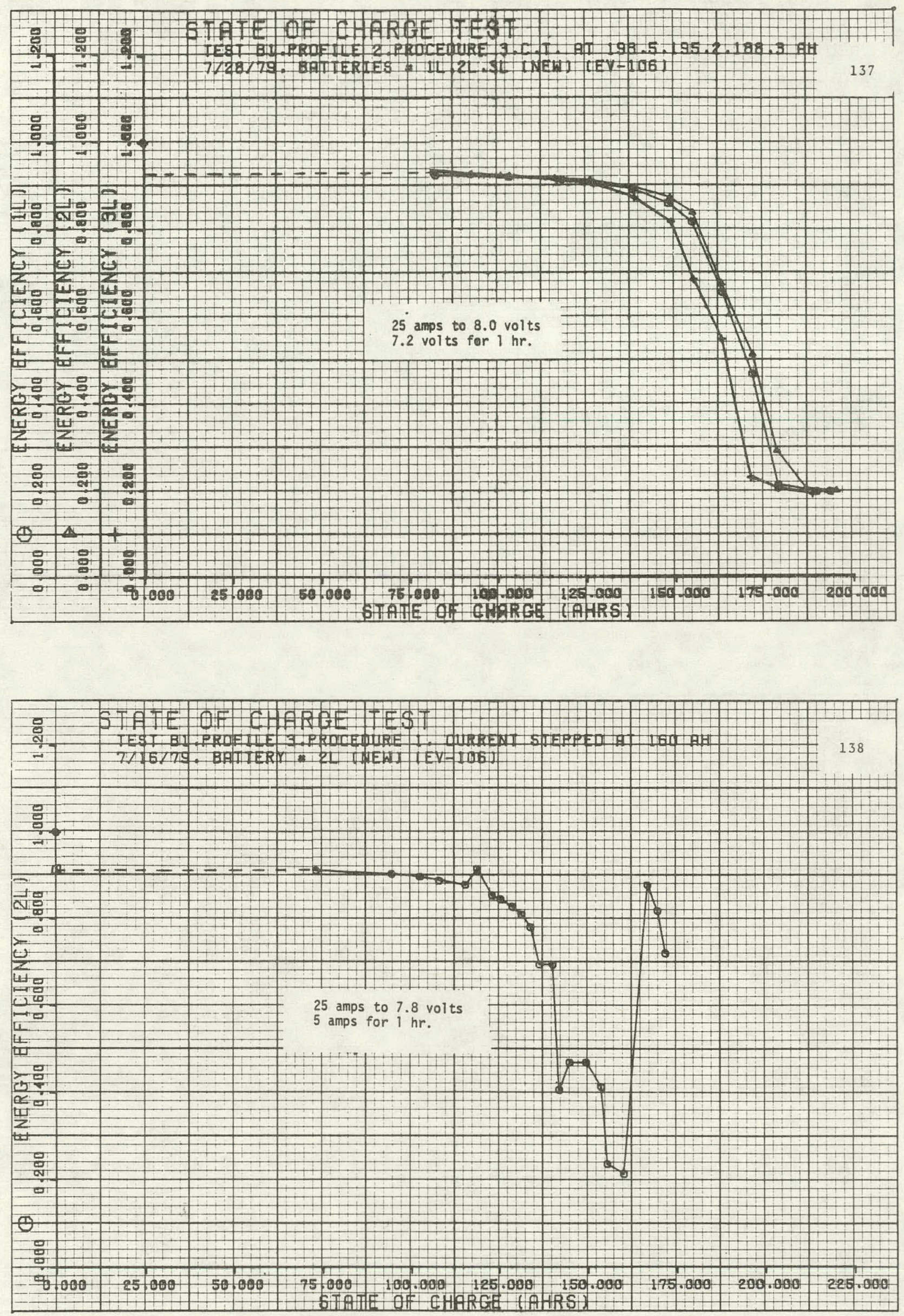

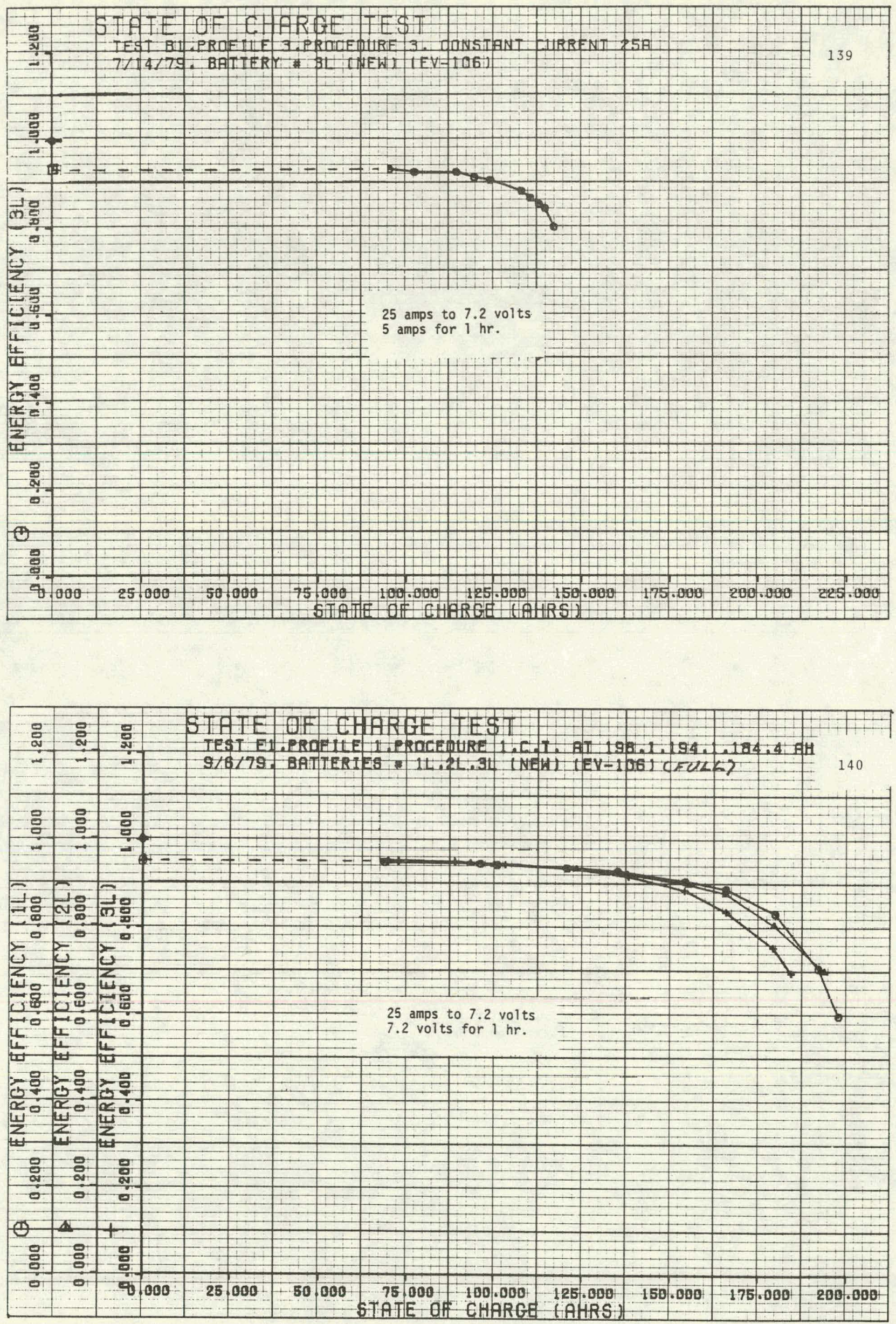

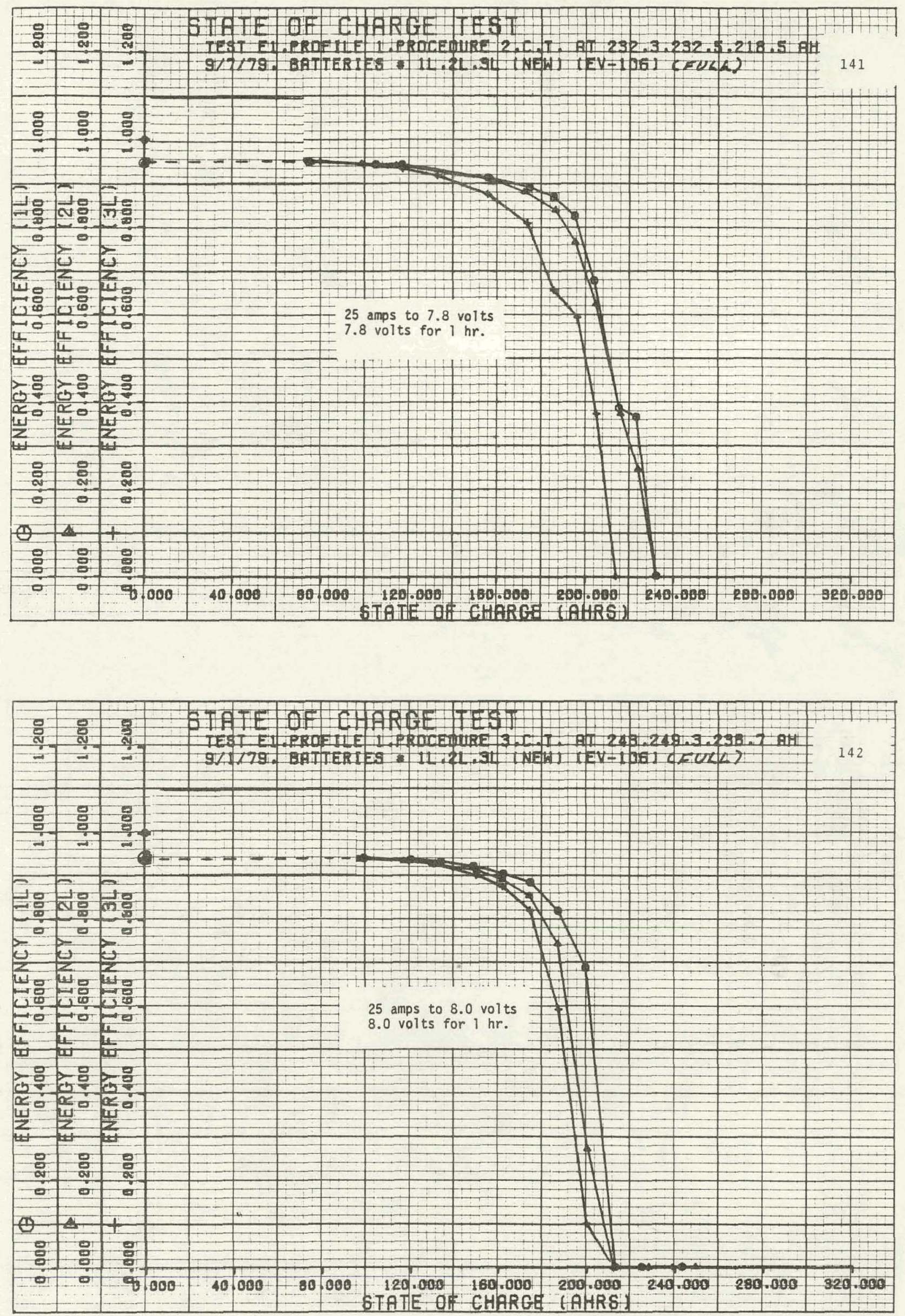

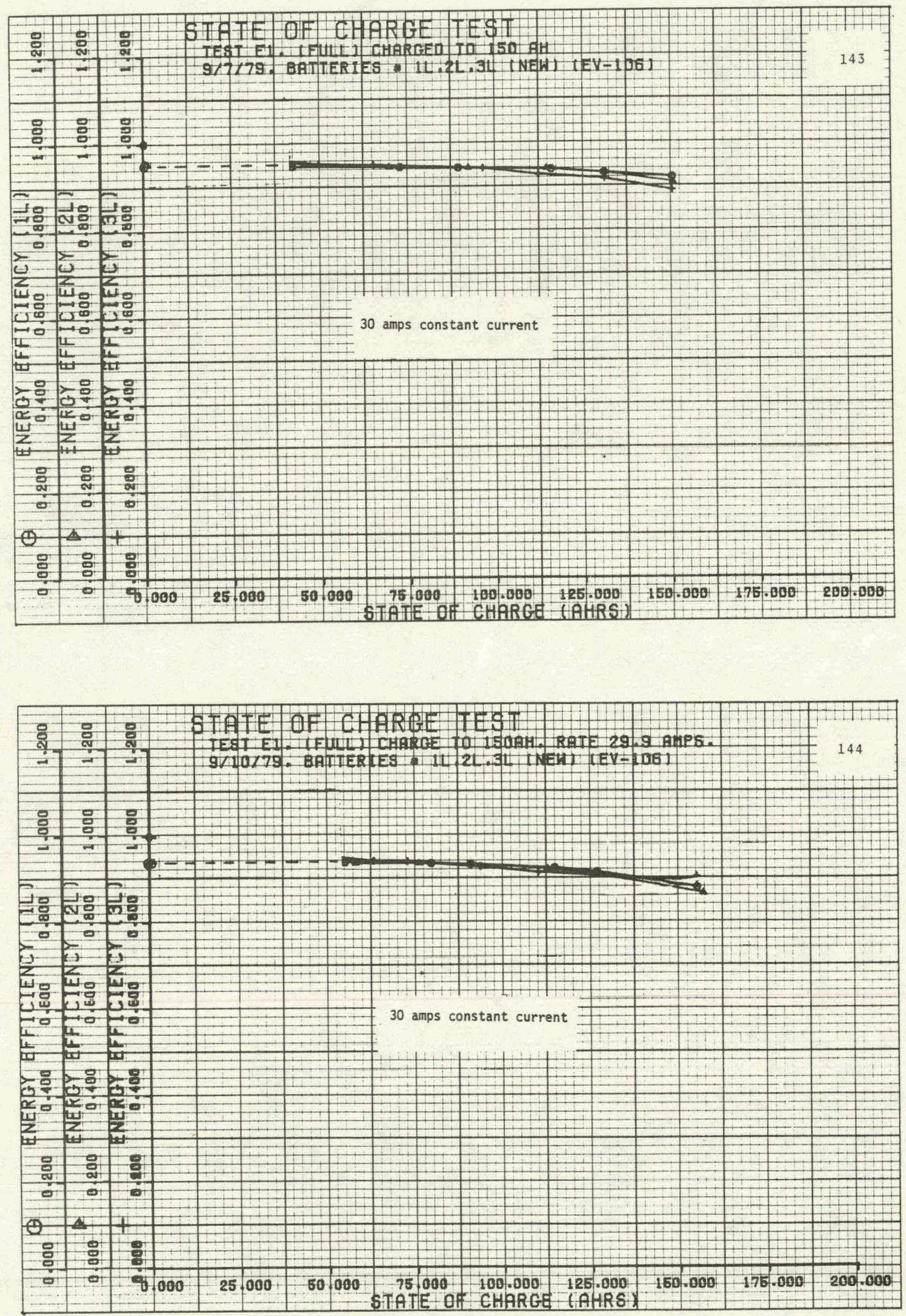

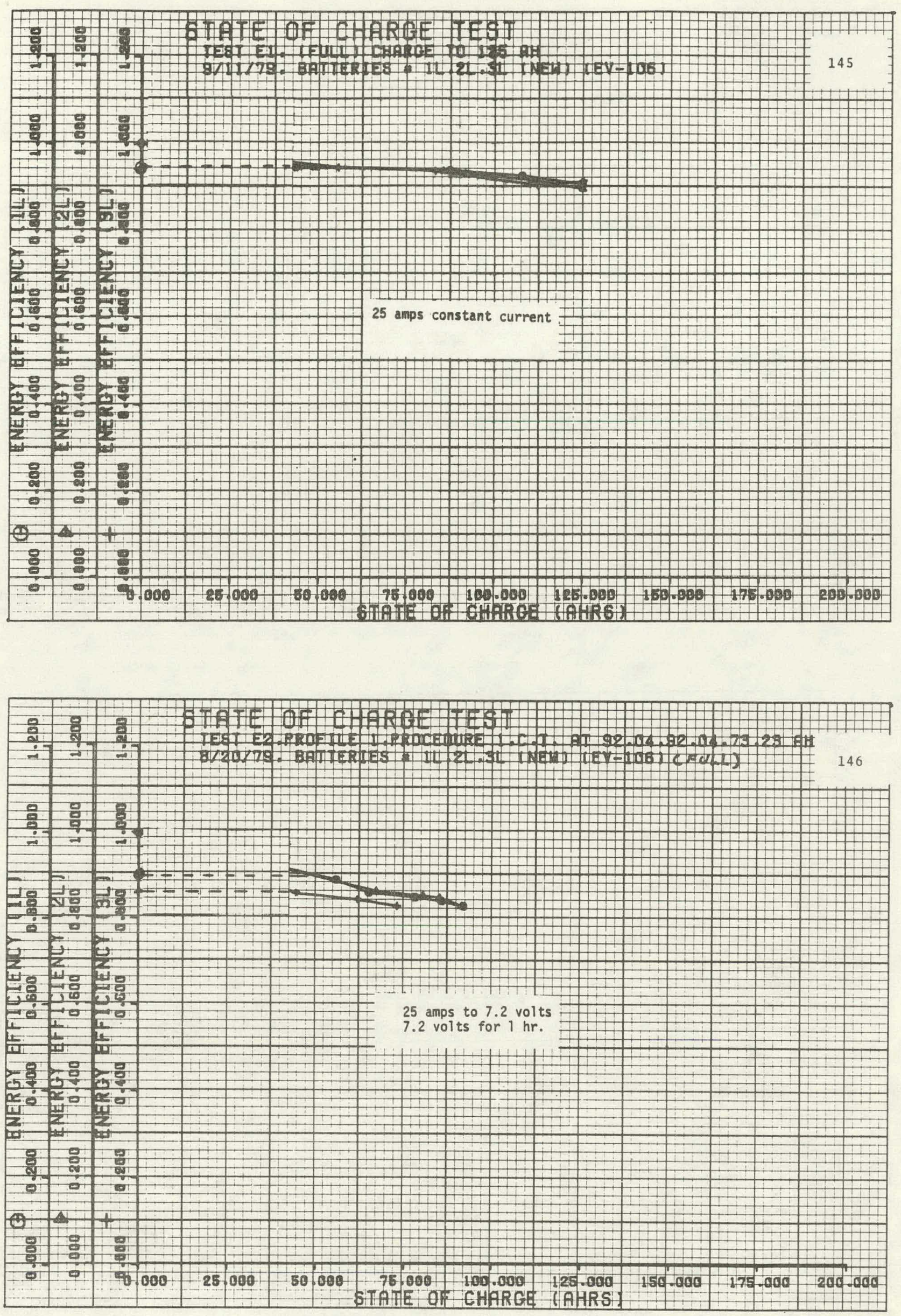

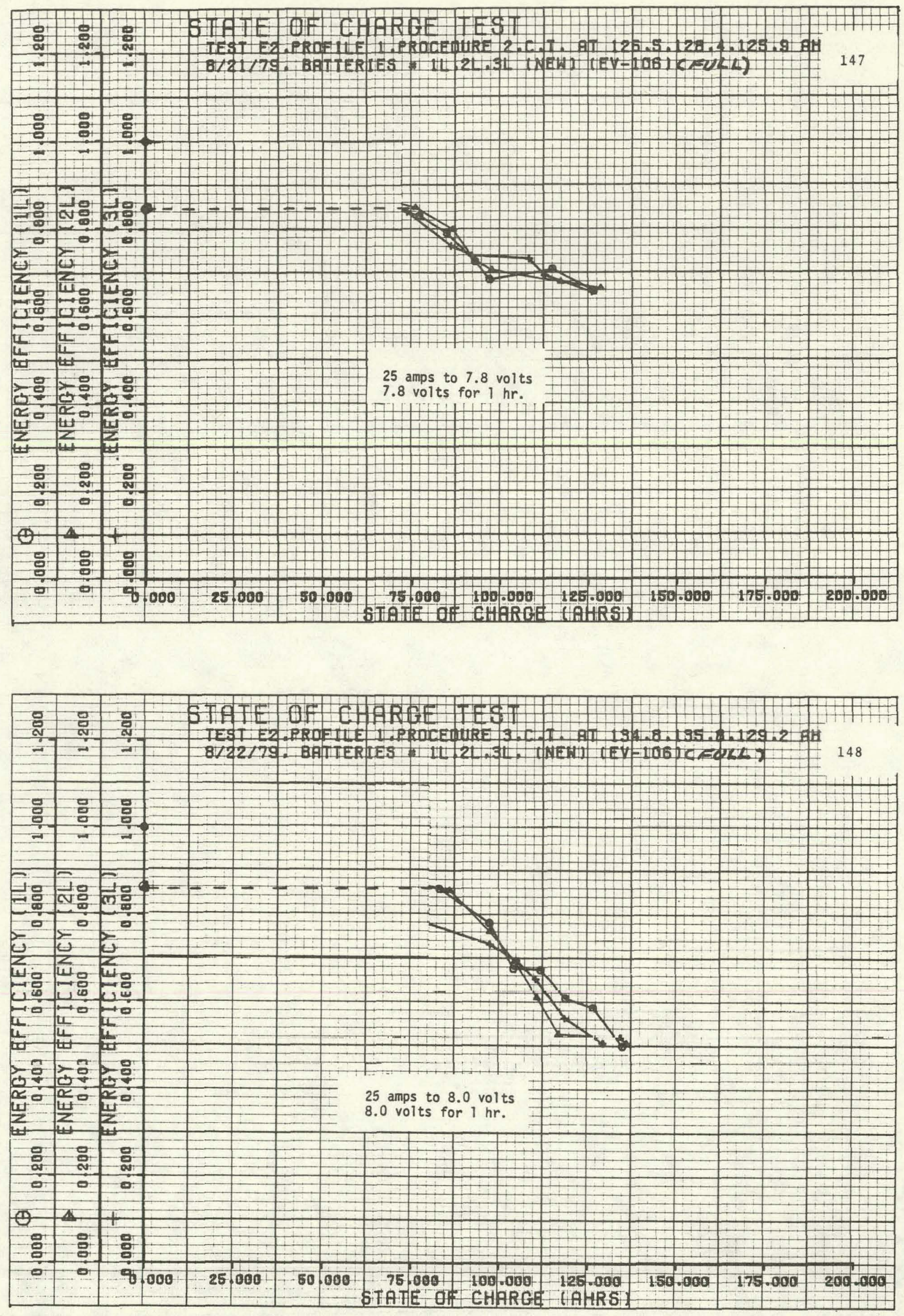

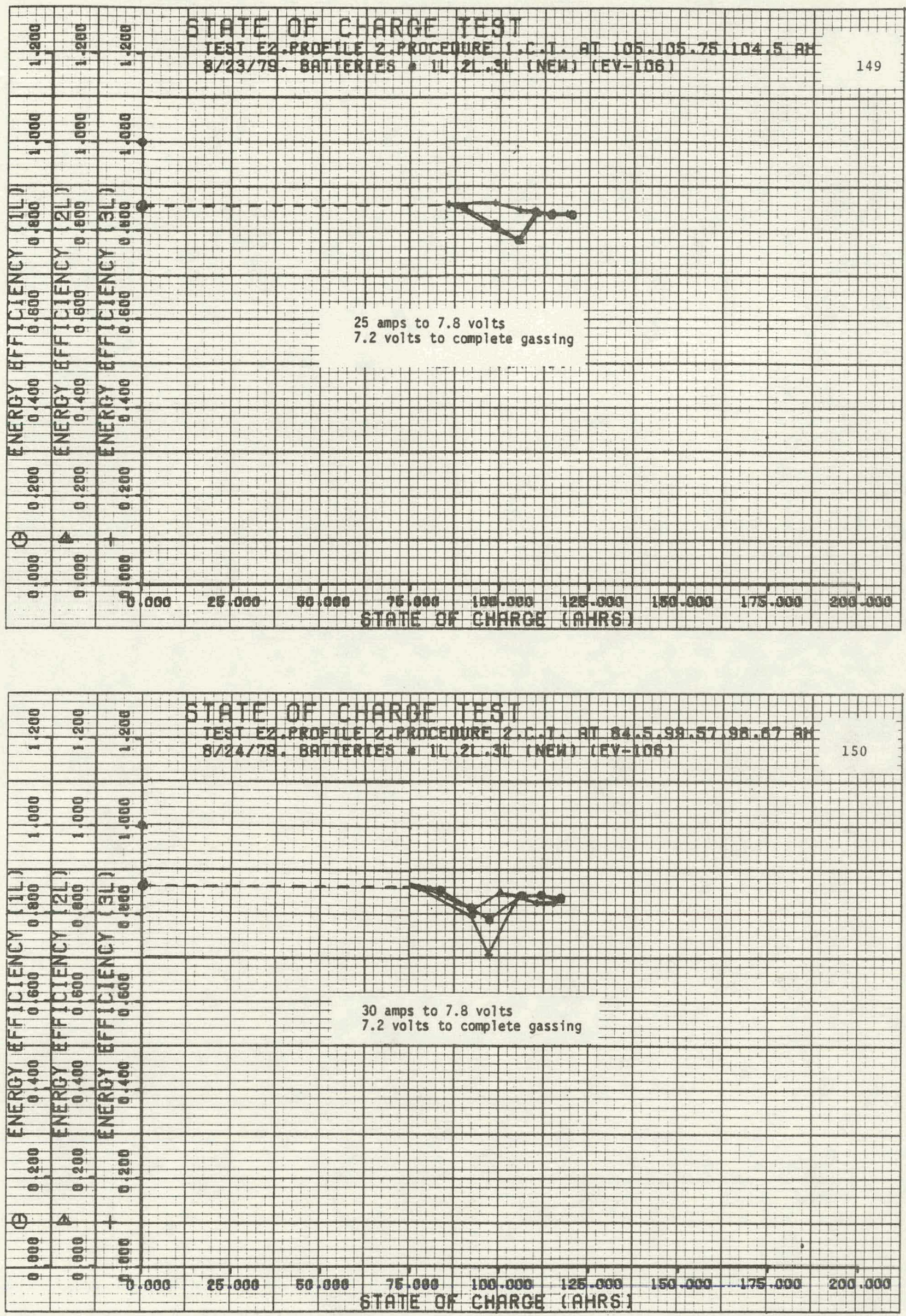


\begin{tabular}{|c|c|c|c|c|c|c|c|c|c|c|c|c|c|c|c|c|c|c|c|}
\hline & & & & STA & TIE & OF & E & 74 & L & & & & & & & & & & 11 \\
\hline & \% & & & TES & $T E$ E & CPRD & FIIE & 2.9 & ROCED & WURE & $3 . C$ & $\pi .5$ & BT 1 & 17.6. & 127. & 1.121 & $.6 \mathrm{~A}$ & 4 & \\
\hline & $\Rightarrow$ & - & 4 & 872 & $5 / 75$ & $\therefore$ BA & ITTER & IES & $=14$ & $2 L \cdot 31$ & $L \mathbb{L}$ & EWI & IEY & 1061 & & 4 & & & 151 \\
\hline & & & $i$ & 4 & $\therefore$ & $\square$ & & & & & & & & 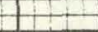 & & & & & \\
\hline & & & & & & & & & & & & & & & & & & & \\
\hline & 뭄 & $\stackrel{2}{\circ}$ & & & & $t \div$ & 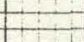 & & & & & & 1 & 1 & 4 & & 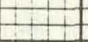 & & \\
\hline & $\rightarrow$ & $\therefore$ & & & $\square$ & {[} & & & & & & & & $H_{1}$ & F & & & & \\
\hline & & & 4 & 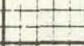 & $\because$ & + & & & $H$ & & & & & $\pi$ & 4 & & $H$ & : & \\
\hline & t to & & $d=$ & & & -1 & $-1=$ & & & & & & & & & & & & \\
\hline & $\mathbb{N D}$ & कis. & 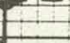 & {$[7$} & 4 & 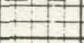 & 4 & $\pi$ & & & & & 110 & $\pi$ & 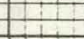 & & 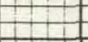 & $4+$ & \\
\hline & 0 & $\infty$ & $T$ & $\pi$ & $+\square$ & $E:$ & & & & & & & & & & & & fis & \\
\hline & $\theta$ & 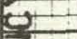 & $\because$ & $\pi$ & $i$ & 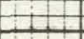 & \pm & & & & & & & $H$ & & & $\pi$ & & \\
\hline & $\omega_{0}$ & 10 & 5 & Z & $\because:$ & $\square$ & & & & & ! & & + & $\ldots$ & E & 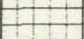 & 4 & 1 & \\
\hline 50 & 0 & 00 & & 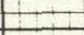 & 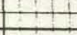 & 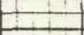 & & $1+5$ & +1 & & & 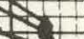 & 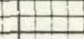 & I & $\pi$ & & 5 & & \\
\hline & $E^{\circ}$ & 120 & 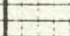 & 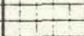 & $\div$ & $E \rightarrow$ & 5 & E: & 5 & & & B & & 4 & 74 & & $\pi$ & & \\
\hline & 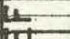 & 4 & $\div$ & $E$ & 4 & 25 an & mpe & 80 & volts & & & & & $\square$ & tr & 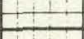 & $\ldots$ & $\square$ & \\
\hline & 0 & & & it & 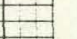 & 7.2 & volts & to com & mplete & gassing & & & & & 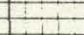 & & $\because$ & & \\
\hline $5 \div$ & 67 & $5 \div$ & & 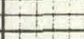 & \pm & & & & & & & & & & & & & & \\
\hline & $\frac{\pi}{4}$ & $\frac{2}{m}$ & & $1+1$ & & & & & & & +5 & 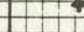 & $T$ & 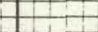 & $\square$ & & & & \\
\hline & $\sum$ & $z$ & $\square$ & L & 4 & $\div 4$ & $1+$ & & & & 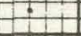 & $\pi$ & & 4 & 4 & & $7+1$ & 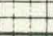 & \\
\hline & & 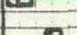 & & & 7 & 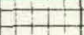 & & & & & & & & & & & & & \\
\hline बूँ & of & कै & $E$ & 4 & 4 & $E$ & 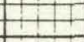 & $E$ & $\pi$ & & H & 4 & $\pi$ & 4 & 4 & $\pi$ & 4 & 3 & 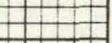 \\
\hline$\sigma$ & 0 & 0 & 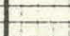 & 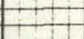 & $7:$ & 21 & 11 & Fit & + & & & +1 & & 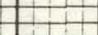 & & & -1 & & \\
\hline & $\sqrt{\Delta}$ & & 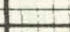 & & & $=$ & & & & & & & & & & & 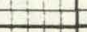 & & \\
\hline 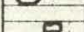 & & & & & & $+\infty$ & 11 & $H$ & 15 & & & & & $\pi$ & & & 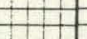 & & \\
\hline 8 & g & 8 & $\square$ & 4 & 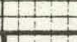 & \pm & t & 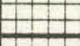 & 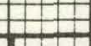 & 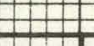 & +4 & 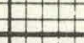 & $\#$ & \pm & $\pi$ & $E$ & 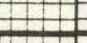 & - & \\
\hline$\infty$ & 0 & क & 000 & 25 & 600 & 50 & 1000 & $\begin{array}{r}75 \\
6 T A 7\end{array}$ & E 0 & $\frac{1090}{\mathrm{CH}}$ & $\begin{array}{l}.000 \\
T^{\circ}\end{array}$ & $\frac{12}{18}$ & $\begin{array}{l}5.000 \\
\text { H.RS }\end{array}$ & 160 & 9.089 & 178 & .600 & & 39.0 \\
\hline
\end{tabular}


APPENDIX D

OPEN CIRCUIT VOLTAGE VERSUS. STATE OF CHARGE FOR ESB EV-106 LEAD-ACID BATTERIES 


\section{THIS PAGE WAS INTENTIONALLY LEFT BLANK}




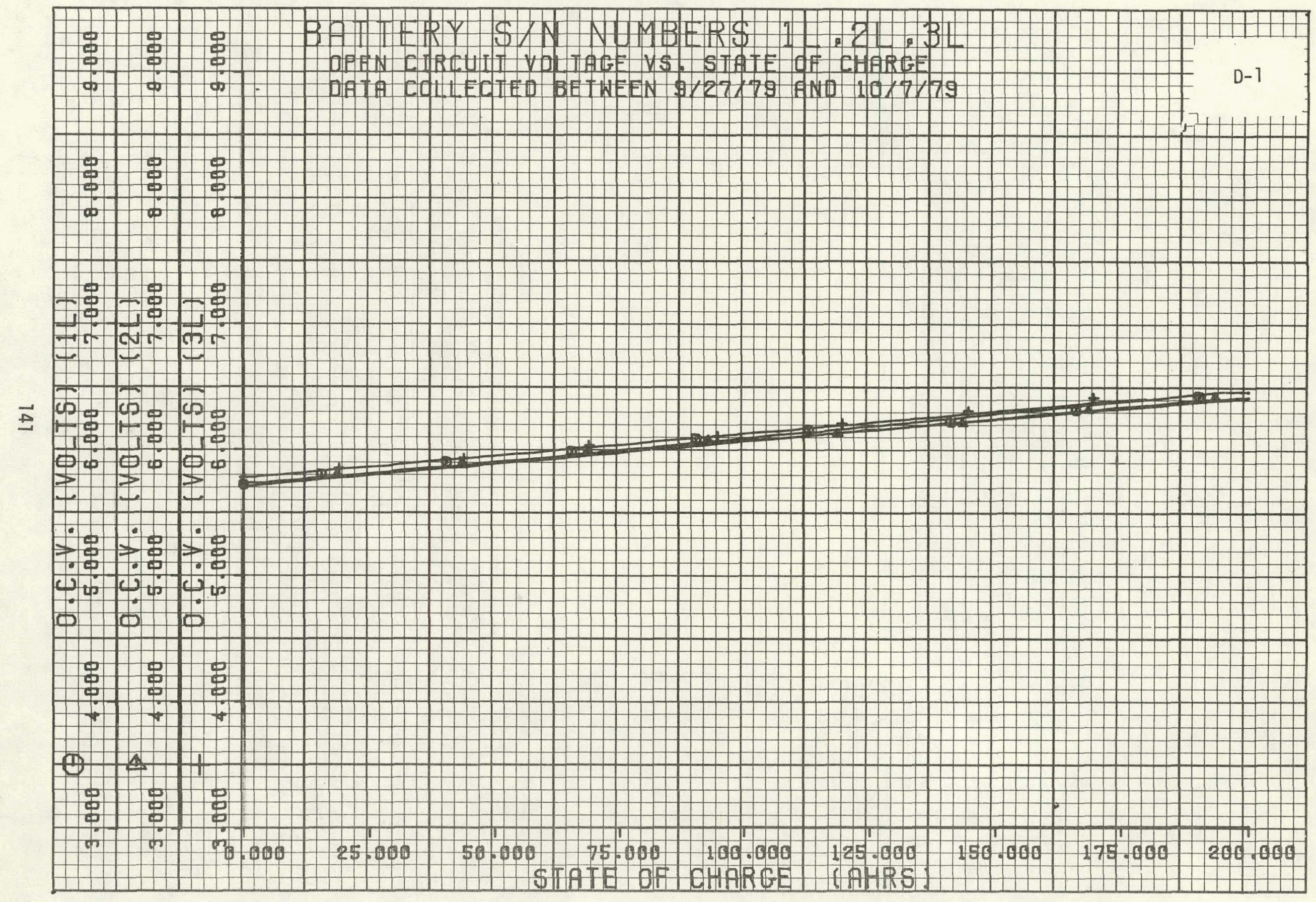




\section{THIS PAGE WAS INTENTIONALLY LEFT BLANK}




\section{APPENDIX E}

ERROR ANALYSIS FOR STATE OF CHARGE INDICATION 
THIS PAGE

\section{WAS INTENTIONALLY \\ LEFT BLANK}


ANALYSIS OF ERRORS FOR STATE-OF-CHARGE INDICATION

NUMBER OF ERRORS LESS THAN $1 \%=19 \%$.

NUMBER OF ERRORS LESS THAN $5 \%=71 \%$.

NUMBER OF ERRORS LESS THAN $10 \%=87 \%$.

MAXIMUM POSITIVE ERROR $30.4 \%$.

MAXIMUM NEGATIVE ERROR $-15.0 \%$.

PERCENT POSITIVE ERRORS $48.4 \%$

PERCENT NEGATIVE ERRORS $51.6 \%$. 


\section{E-2}

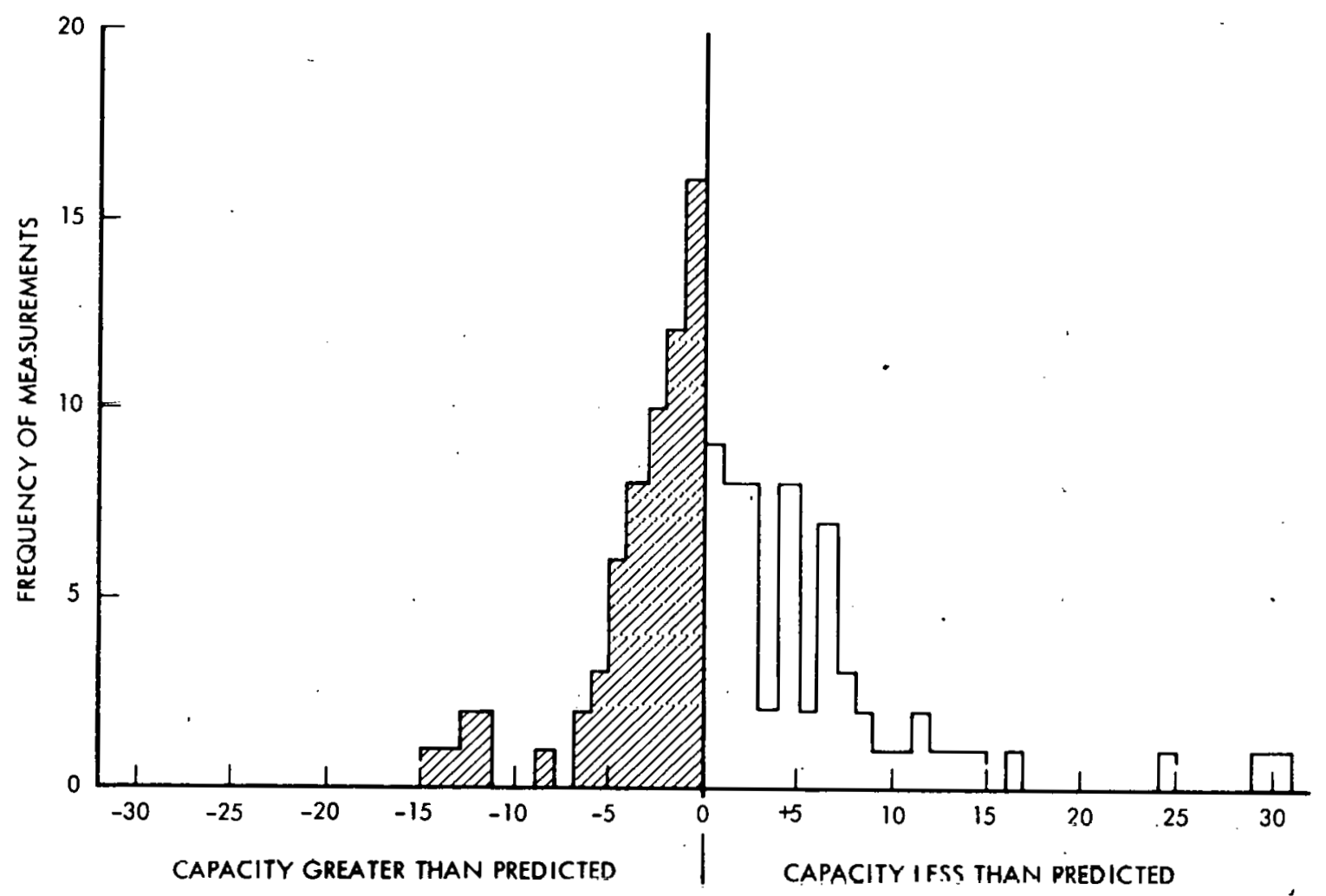

Figure 5. Error Distribution for Capacity Prediction 